\title{
REPAIRING FRACTURED LANDSCAPES: NEW CONNECTIONS TO THE WESTERN TORONTO WATERFRONT
}

\author{
by \\ Alicia Kingdon \\ BBA, Simon Fraser University, 2013 \\ A Major Research Paper \\ presented to Ryerson University \\ in partial fulfillment of the requirements for the degree of \\ Master of Planning \\ in \\ Urban Development
}

Toronto, Ontario, Canada, 2015

(c) Alicia Kingdon 2015 
I hereby declare that I am the sole author of this MRP. This is a true copy of the MRP, including any required final revisions.

I authorize Ryerson University to lend this MRP to other institutions or individuals for the purpose of scholarly research

I further authorize Ryerson University to reproduce this MRP by photocopying or by other means, in total or in part, at the request of other institutions or individuals for the purpose of scholarly research.

I understand that my MRP may be made electronically available to the public. 


\title{
Repairing Fractured Landscapes: New Connections to the Western Toronto Waterfront
}

\author{
(C) Alicia Kingdon, 2015 \\ Master of Planning \\ in \\ Urban Development \\ Ryerson University
}

\begin{abstract}
The project presents a new vision for the Western Toronto Waterfront. The project proposes a design to reimagine the forgotten territories in Parkdale and reconnect the historic waterfront resort community to Lake Ontario. Using tools supplied by landscape urbanism and the architectural practice of landform building, the project seeks to reimagine the territories left abandoned because of their close proximity to road and rail infrastructure.
\end{abstract}

Key words: urban design; landscape urbanism; landform building; Toronto; Parkdale 


\section{Acknowledgements}

A special thank you to Dr. Shelagh McCartney for her guidance and direction throughout this project. Her perspective and design sensibilities were invaluable to the completion of this work. Thank you also to Dr. Pamela Robinson for her thoughtful and constructive feedback. 
Contents

1.0 Introduction 1

2.0 Literature Review

$\begin{array}{ll}2.1 \text { History } & 5\end{array}$

2.1.1 Grand Trunk Railway $\quad 6$

2.1.2 Grade Separation Project (1911) 8

2.1.3 Toronto Waterfront Plan (1912) 9

2.1.4 Gardiner Expressway 13

2.2 Disconnecting/Reconnecting to the Waterfront 18

2.3 Modifying the Landscape $\quad 21$

2.3.1 Re-examining Transportation Infrastructure $\quad 21$

2.3.2 Landscape Urbanism to Reimagine Transportation Infrastructure 25

2.3.3 Using Landscape Urbanism - Landform Building 28

2.3.4 Reconstruction $\quad 30$

2.4 International Case Precedents $\quad 32$

2.4.1 Olympic Sculpture Park, Seattle

2.4.2 Ronda Litoral, Barcelona 33

2.4.3 Central Artery/Tunnel Project, Boston 35

3.0 Research Methodology 37

3.1 Method 1: Identifying Neighbourhood Boundaries 37

3.2 Method 2: Parkdale Park Space Calculation 38

3.3 Method 3: Site Modeling, Identifying and Applying Case Precedents 40

3.4 Method 4: Site Visit - Identifying Connectivity in Olympic Sculpture Park 42

4.0 Findings 44

4.1 Results from Method 1: Boundary of Parkdale 45 
4.2 Results from Method 2: Percentage of Park Space Calculation 49

4.3 Results from Method 4: Learnings from Seattle Olympic Sculpture Park 49

5.1 Design Vision $\quad 56$

5.2 The Proposed Development

$\begin{array}{ll}\text { 5.2.1 Built Form } & 57\end{array}$

5.2.2 Building Height

$\begin{array}{ll}\text { 5.2.3 Podium } & 58\end{array}$

5.2.4 Mixed Uses

$\begin{array}{ll}5.2 .5 \text { Setbacks } & 59\end{array}$

5.2.6 Frontage

5.3 The Proposed Landscape Bridge 59

6.0 Design Discussion

6.1 Bridging: Connecting Parks to Arrange a Neighbourhood 61

6.2 Planning for Growing/Diverse Communities 64

6.3 Planning and Urban Design Rationale $\quad 68$

$\begin{array}{ll}\text { 6.3.1 Provincial Policy } & 68\end{array}$

6.3.2 Municipal Policy

6.4 Study Next Steps $\quad 76$

$\begin{array}{ll}7.0 \text { Conclusion } & 77\end{array}$

Appendix A: Park Space Calculation Results 79

References $\quad 83$

Image References $\quad 89$ 


\section{List of Figures}

Figure 1 Western Toronto Waterfront ………………...........................................................................................

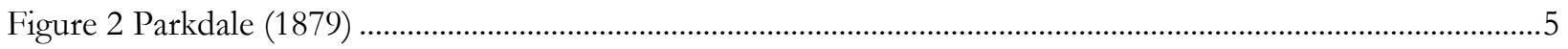

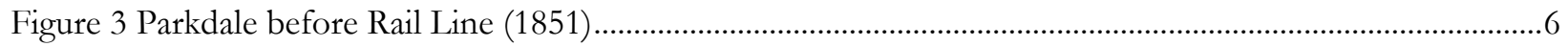

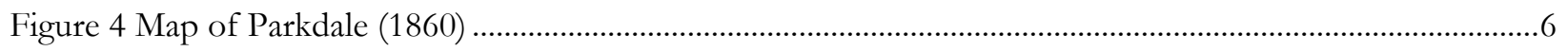

Figure 5 Goad Map Fire Insurance Map (1884) Figure 6 Goad Map Fire Insurance Map

(1890)

Figure 7 Track, looking west from east of Jameson Avenue crossing (1910) ......................................................

Figure 8 Temporary wooden bridge used during grade separation activities, Jameson Avenue (1911)...............9

Figure 10 Goad Fire Insurance Map (1924) ....................................................................................................... 10

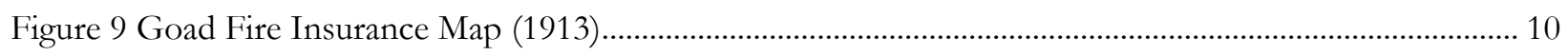

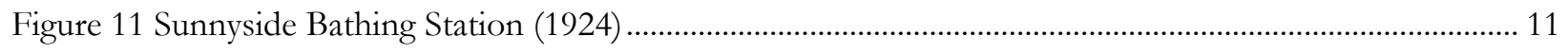

Figure 12 Sunnyside, looking n.w., showing St. Joseph's Hospital (formerly Sacred Heart Orphanage), The

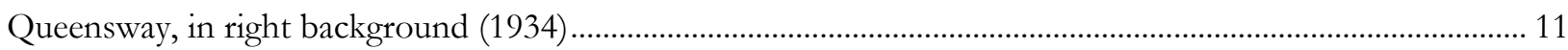

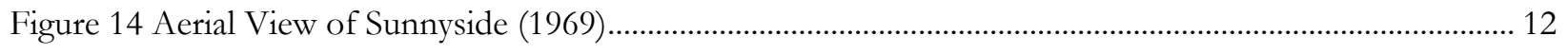

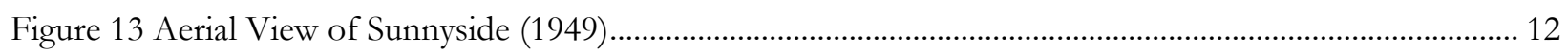

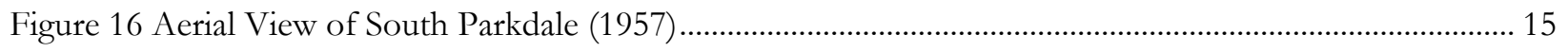

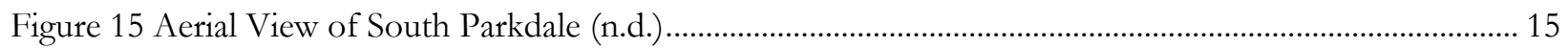

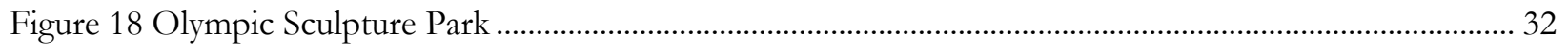

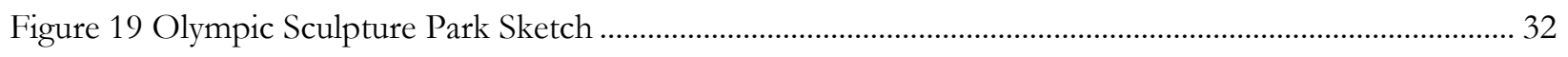

Figure 20 Section of Ronda Litoral, Barcelona ………..................................................................................... 33 
Figure 21 Downtown Boston Before and After the Boston Big Dig.

Figure 22 Mapped Neighbourhoods and Park Space in Toronto

Figure 23 Calculated Park Space and Neighbourhood Space

Figure 24 Parkdale Model Boundaries......

Figure 25 Seattle’s Olympic Sculpture Park Boundaries......

Figure 26 City of Toronto Neighbourhood Boundary 45

Figure 27 Rail Line (looking south at Jameson Ave. and Springhurst Ave.) ....... 46

Figure 28 Rail Line (looking west at Jameson Ave.). 46

Figure 29 Looking north to Parkdale from Marilyn. 46

Figure 30 Gardiner Expressway (looking east from Gardiner Expressway) 46

Figure 31 Looking north to Parkdale from Jameson Ave. Pedestrian Bridge. 47

Figure 32 Looking west from Dunn Ave. .47

Figure 33 New Parkdale Neighbourhood Boundaries 48

Figure 34 Map of Olympic Sculpture Park 50

Figure 35 Seating and Views 52

Figure 36 Multiple Pathways 52

Figure 37 Multiple Users. 52

Figure 38 Proposed Design Plan View 54

Figure 39 Proposed Design Axonometric View 55

Figure 40 Parkdale Green Space Network 62 


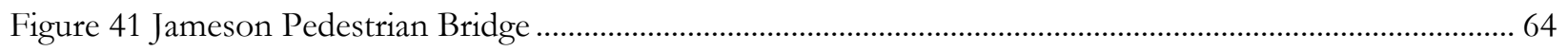

Figure 42 Jameson Pedestrian Bridge 'Do Not Cross'........................................................................................... 64

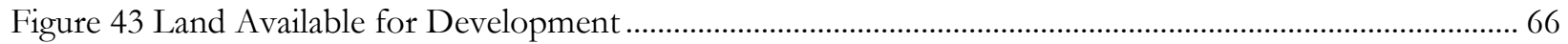

List of Tables

Table 1 Provincial Policy Statement Supporting Policies ....................................................................................... 68

Table 2 City of Toronto Official Plan Supporting Policies ................................................................................... 70

Table 3 Central Waterfront Secondary Plan Design Principles \& Supporting Policies ....................................... 73 


\subsection{Introduction}

Located on the western edge of downtown Toronto, the Western Toronto Waterfront occupies approximately 120 hectares and includes undeveloped shoreline, public space and historic sites. This area not only occupies some of the city's most underused and undervalued public space, it also serves as a vital transportation corridor, with major transportation infrastructure including the Gardiner Expressway, Lake Shore Boulevard and the CN railway corridor The importance of the Western Toronto Waterfront was identified by the City of Toronto, when the City undertook the Western Toronto Waterfront Master Plan in 2009.

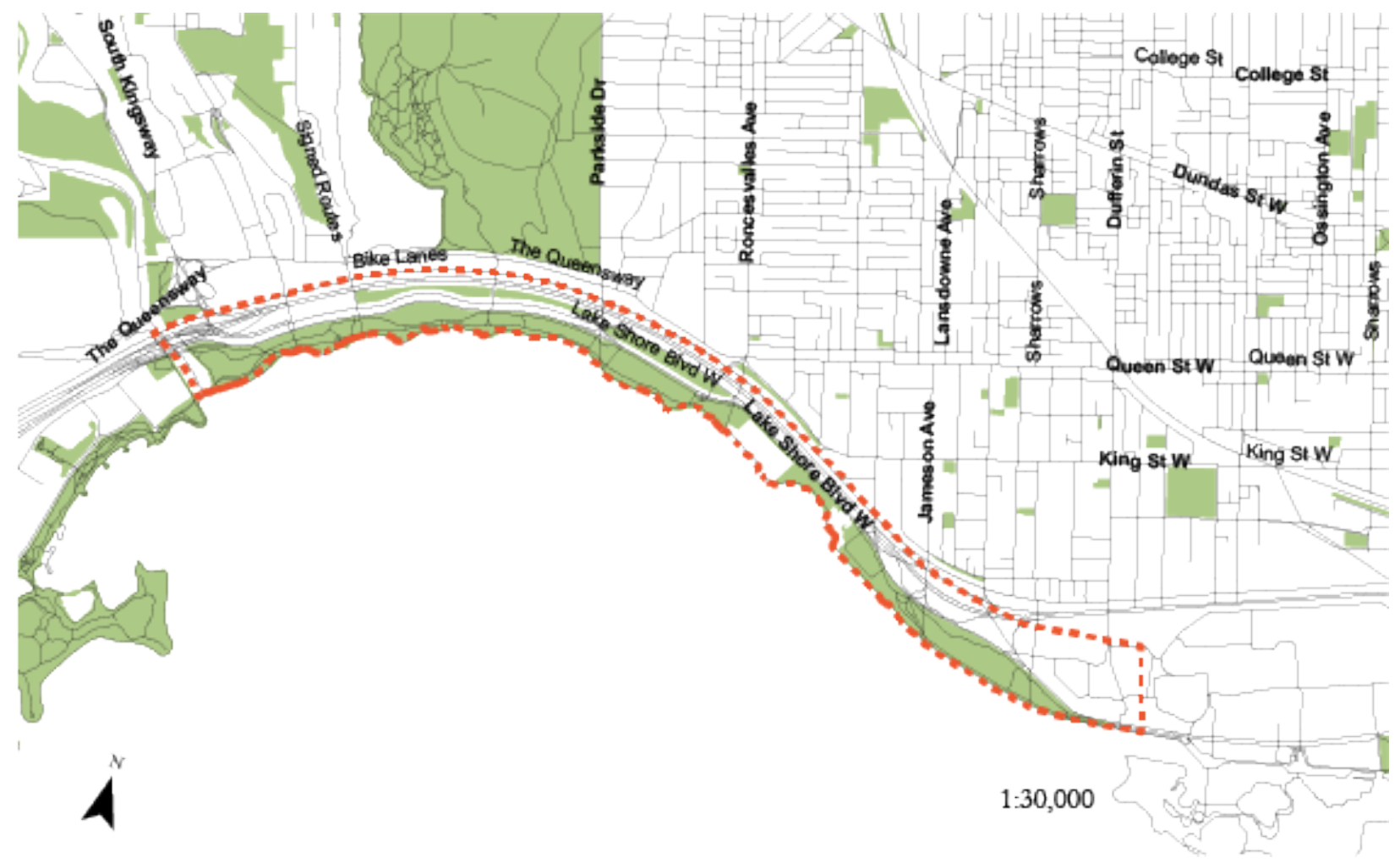

Figure 1 Western Toronto Waterfront

In this plan the area of the Western Toronto Waterfront is defined by the mouth of the Humber River to the west, Marilyn Bell Park to the east, the CN Railway Corridor to the north and Lake Ontario to the south. The Western Toronto Waterfront Master Plan was approved by the City of 
Toronto Council in 2009 and calls for several ambitious long term projects and several short term interventions, however six years after its approval many of these projects remain unrealized today (City of Toronto, 2009).

Prior to the creation of the Western Toronto Waterfront Plan, the area had undergone several major transformations. Recent improvements to the Western Waterfront include the construction of the Humber River pedestrian bridge, improvements and redesign of the Martin Goodman Trail, development of the western beaches waterfront and the redesign of Marilyn Bell Park (City of Toronto, 2009). Despite these transformations this area has stood at the periphery of planning focus. The Western Toronto Waterfront remains largely outside the purview of the established Waterfront Toronto and thus the area has experienced an uncoordinated planning effort. The majority of these designs have been restricted to the water edge, with few north-south connections present. While these improvements have enhanced the western water's edge, these efforts remain largely uncoordinated and have failed to connect the waterfront to the surrounding communities. Projects that have focused on the waterfront have continued to develop the Western Waterfront as a city park but has neglected to address the connections to the surrounding neighbourhoods. This isolated development has plagued the Western Waterfront, giving it a perceived sense of remoteness for local residents (City of Toronto, 2009). In addition, much of the land in this area is underused as it is "located between major pieces of transportation infrastructure, including The Queensway and CN Rail Corridor, Gardiner Expressway, Lake Shore Boulevard and the Gardiner Expressway, and within the median of Lake Shore Boulevard itself' (City of Toronto, 2009, p. 44). This sense of remoteness followed the construction of these infrastructural systems; in the early 1900s the Western Waterfront thrived as a resort community for Toronto residents. This historical waterfront relationship illustrates the potential of the Western Waterfront to redevelop these unused spaces and redefine its relationship to the lakeshore. Coupled with the current growing 
development pressures in the City of Toronto, this area represents an untapped resource and holds many opportunities for the private and public development of its over 30 hectares of underused open space (City of Toronto, 2009).

Two neighbourhoods lie adjacent to the Western Toronto Waterfront, Swansea and Parkdale, both of which are gateways to the waterfront for their neighbourhoods to the north. This project will focus on developing a connection in the neighbourhood of Parkdale as the area is both experiencing development pressures from developers moving west from outside the downtown core and is identified by the City of Toronto as a Priority Neighbourhood (i.e. a neighbourhood lacking community infrastructure) (City of Toronto, 2014). Parkdale's close proximity to Toronto’s downtown core has created an increased real estate demand in the area. These pressures sparked the West Queen West Development Study which is currently underway in the neighbourhood of Parkdale (City of Toronto, 2014). Along with the development pressure there is also an identified need for community resources. South Parkdale, which is identified by the City of Toronto as a Neighbourhood Improvement Area, has an average after-tax household income of $\$ 41,032$ (City of Toronto, 2011). This is in stark contrast to the City of Toronto, which has an average after-tax household income of $\$ 70,945$ (City of Toronto, 2011). There is an identified need for development within this community that preserves and adds to the existing housing stock, improves the connection to the waterfront and enhances and creates community infrastructure within the neighbourhood.

The goal of this design project is to create connections to Toronto's Western Waterfront through the establishment of strong pedestrian connections, which make use of the underused open space along the Western Waterfront. Due to infrastructural barriers, potential pedestrian and cyclist connections are met with cost and feasibility challenges. The aim of this paper is to explore and 
propose potential pedestrian connections in this area that leverage development to offset cost and reconnect to the waterfront.

To develop an understanding of the appropriate planning intervention, the history of the Western Waterfront was examined, a literature review of landscape urbanism and landform building was conducted and an examination of successful design projects was undertaken to provide guidance and to help identify opportunities for a possible connection. In addition, case precedents of successful waterfront connections at various scales were identified and examined to illustrate best practices and lessons learned. This work was evaluated to create an urban design proposal that seeks to reconnect the community of Parkdale to the waterfront. The goal of the design project is to reconnect the waterfront and develop a design that allows the area to serve a dual purpose as waterfront destination and a travel corridor. 


\subsection{Literature Review}

\subsection{History}

This section focuses on the historic development of the neighbourhood of Parkdale and its evolution from a wealthy suburb with a strong connection to the water, to a low-income community that has turned its back on the water. Through this transition over approximately 150 years a succession of projects that introduced infrastructure, acting as barriers to the waterfront, were added. The development and subsequent impacts of four major projects and time periods are examined, including: the development of the Grand Trunk Railway, the Railway Grade Separation Project, The Toronto Harbourfront Commission 1912 Waterfront Development Plan and the construction of the Gardiner Expressway. Each of these projects produced an infrastructural layer that further divided the community of Parkdale from the waterfront and the parkland it relied so heavily upon.

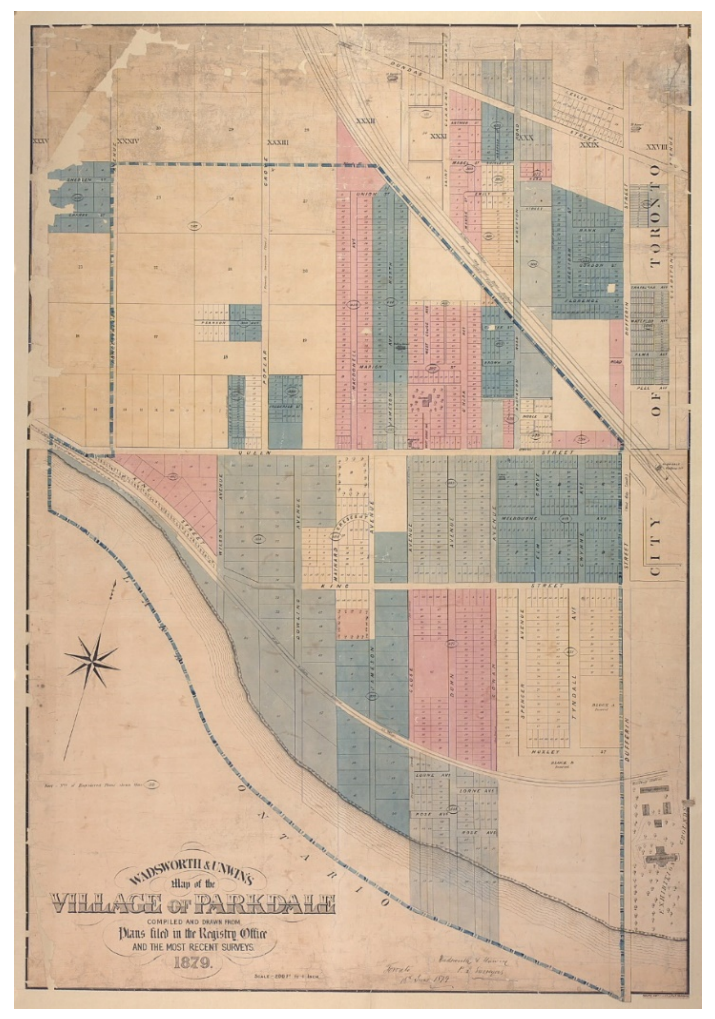


Located in the south-western edge of downtown Toronto, Parkdale, originally called 'the Flowery Suburb,' was one of the first suburbs of Toronto (Whitzman, 2010). Historically Parkdale was one of the few sections of non-industrialized shorelines in the Toronto area (see fig. 2). During this time, Parkdale flourished as a suburban community, a retreat from the city. Parks played an important role in the desirability and social life of the neighbourhood. The shoreline that extended along the edge of Parkdale was a popular place among residents, serving as a favourite destination in the local community and Toronto as a whole, however with each added barrier, the lakeshore became more difficult to access changing the once popular beach town to a town that is currently disconnected from the waterfront.

\subsubsection{Grand Trunk Railway}

Before its development as a suburb of the growing City of Toronto, Parkdale received its first detachment from the lakeshore with the construction of the Grand Trunk Railway. In 1852 the Grand Trunk Railway Company of Canada constructed the Grand Trunk Railway from west of Toronto to Montreal. The railway ran adjacent to the lakeshore in the area that is now Parkdale.
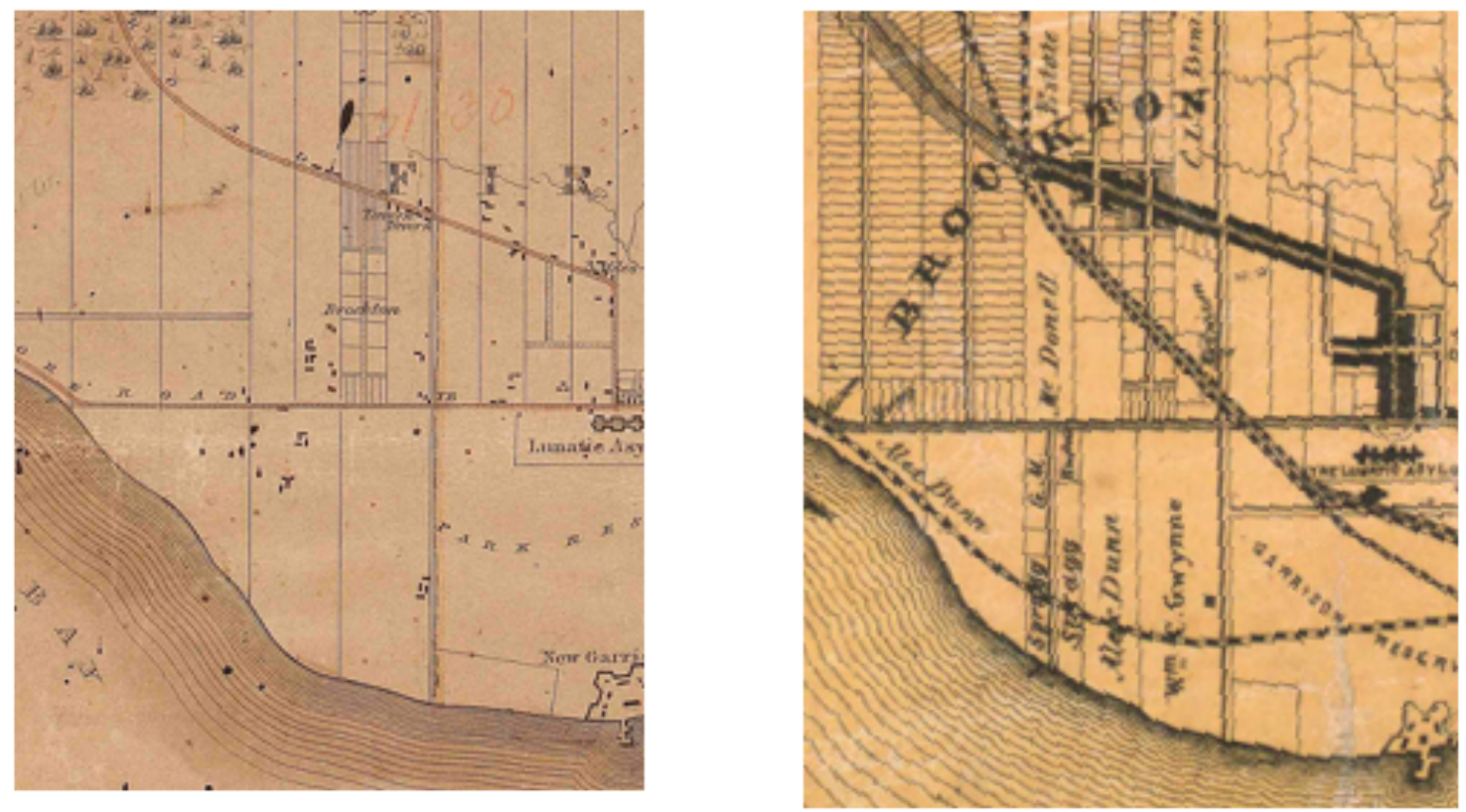
Prior to the development of the railway the area was undeveloped with few local roads. As Parkdale continued to grow, the railway continued to impede access to the lakeshore; however, local roads continued to develop around the railway and extended to the lakeshore. This development to the lakeshore can be seen between the periods of 1851 and 1860. The map of Parkdale in 1851 (see fig. 3) illustrates the suburb prior to residential development and the construction of the rail line. The map of Parkdale in 1860 (see fig. 4) shows Parkdale after the construction of the rail line. Although acting as a barrier, as the map illustrates, the railway itself did not pose a significant obstacle as roads and development continued to extend to the lakeshore.

The continued development of Parkdale resulted in its incorporation as a village in 1878 and its annexation by the City of Toronto in 1889 shortly thereafter (Whitzman, 2003). The population of Parkdale grew quickly during this time, from 2000 in 1886 to approximately 4000 in 1888 (City of Toronto Archives, n.d.a). It was during this time that Parkdale flourished as a retreat for Toronto's wealthy, who began to set up cottages and homes in close proximity to the water, and a day resort for the rest of Toronto's residents (Whitzman, 2003). South Parkdale provided an ideal home for residents to live on the periphery of the built-up city as Parkdale had close proximity to the water and offered a pastoral lifestyle (Whitzman, 2003). This increase in development can be seen between 1884 and 1890 time period. Figure 5 and 6 illustrate the continued development in Parkdale and the beginning progression of development below the railway track, along the lakeshore. 


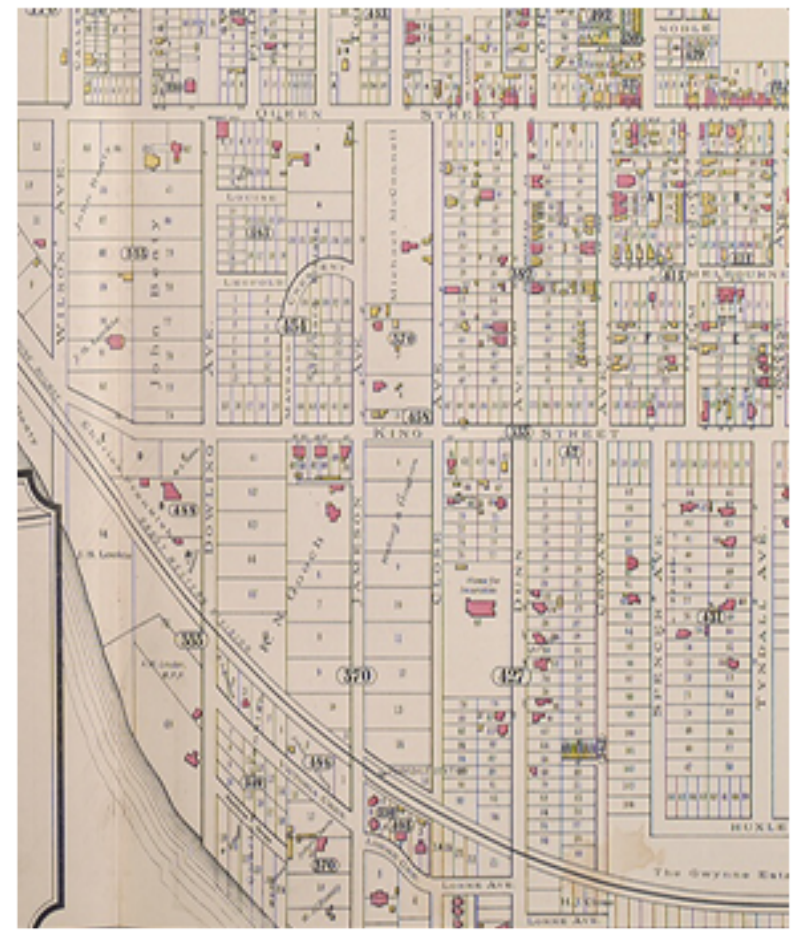

Figure 5 Goad Map Fire Insurance Map (1884)

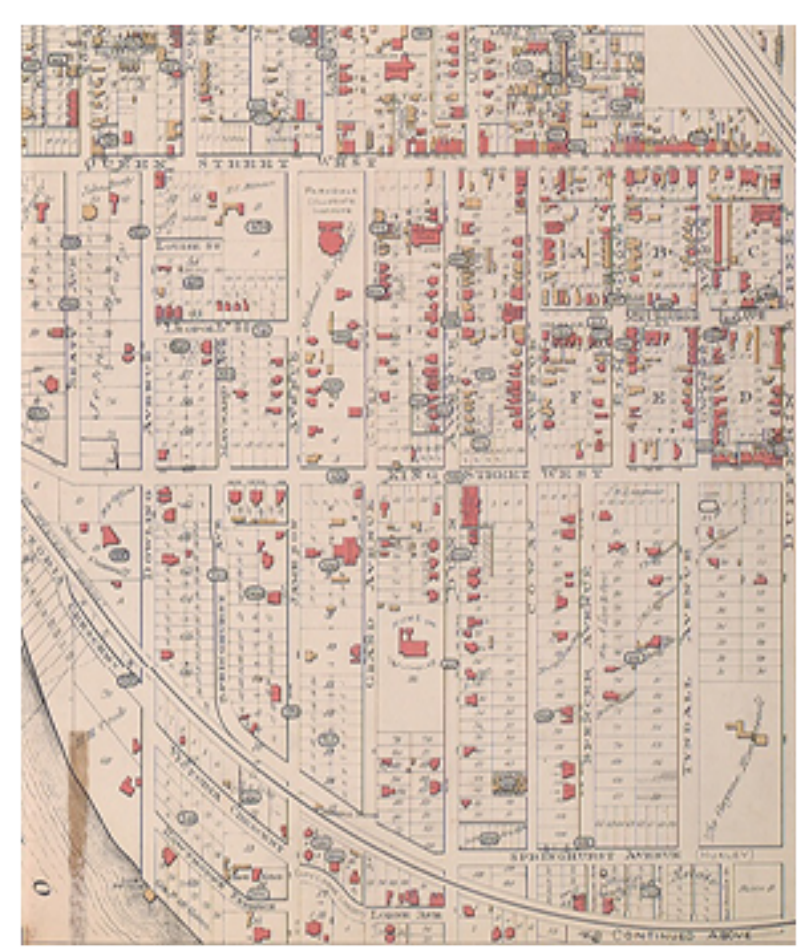

Figure 6 Goad Map Fire Insurance Map (1890)

The success of Parkdale as a waterfront destination, in spite of the railway construction illustrates that despite the presence of a physical barrier, with proper connection and attractions to and along the waterfront, the lakeshore can still serve as an important focal point in the local community.

\subsubsection{Grade Separation Project (1911)}

The grade separation of project of 1911, which was developed to facilitate higher speed railcars, drastically altered the landscape of the waterfront (see fig. 7 and 8) and created one of the more significant barriers to the lakeshore (City of Toronto Archives, n.d.b). Separating the Grand Trunk Railway below grade reduced Parkdale's access to the waterfront to four streets. In addition the large break in the landscape created an obtrusive presence and a perceived barrier for people and wildlife. The infrastructure once allowed crossing along local tracks. The new grade separated system, while increased flows of trains, made crossing only possible at four locations. 
The grade separation project occurred alongside the beginning of the decline of Parkdale's days as a wealthy suburb. During this time the influx of wealthy residents began to stall; however, Parkdale still remained as a destination for others to access the lakeshore. Rowing, yacht clubs and private boathouses began to populate Parkdale's lakefront by the 1910s (Whitzman, 20010). This popularity of the waterfront helped spur development of the comprehensive Toronto Waterfront Plan of 1912 (Desfor, Goldrick and Merrens, 1989).

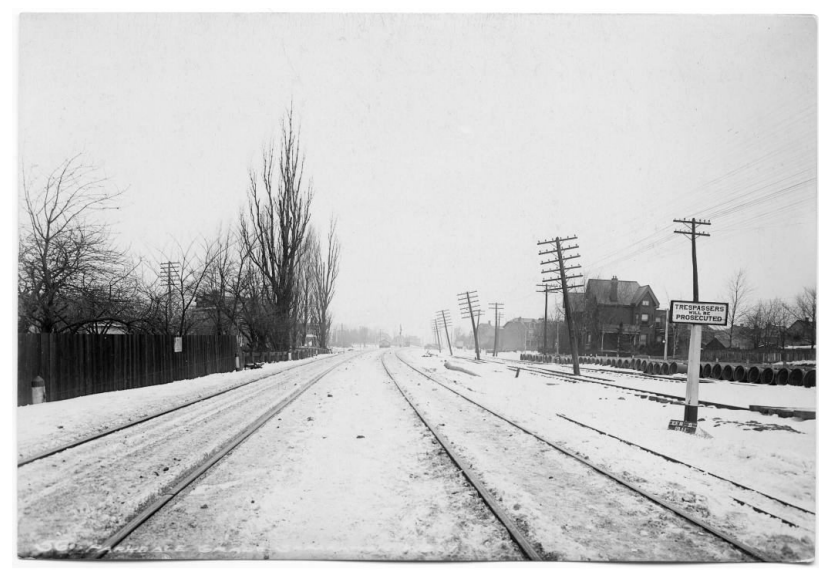

Figure 7 Track, looking west from east of Jameson Avenue crossing (1910)

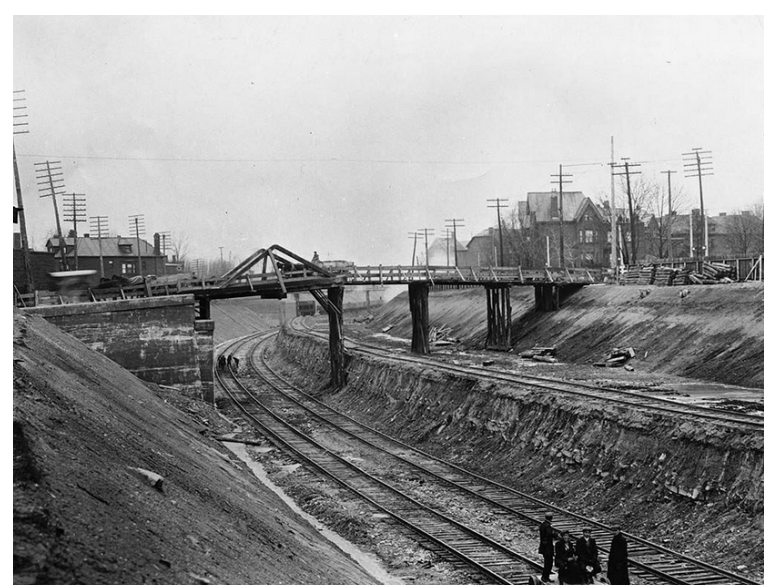

Figure 8 Temporary wooden bridge used during grade separation activities, Jameson Avenue (1911)

\subsubsection{Toronto Waterfront Plan (1912)}

Toronto's Waterfront Development Plan was developed by the Toronto Harbour Commissioners (THC). The plan, developed in 1912 and projected to take eight years, outlined the Commissioners' vision for growth along the waterfront in industrial development, commercial and dock development and park and boulevard improvements (The Toronto Harbour Commissioners, 1913; Lehrer and Laidley, 2008; City of Toronto, 2009). The total cost was $\$ 20$ million and included in this comprehensive plan were extensive shoreline expansion plans and recreational development 
in the Sunnyside area just southwest of Parkdale (Lehrer and Laidley, 2008; The Toronto Harbour Commissioners, 2013). The plan also included a large scale program of land reclamation (Lehrer and Laidley, 2008). In the eight year period the THC created over 100 hectares of new land in the area
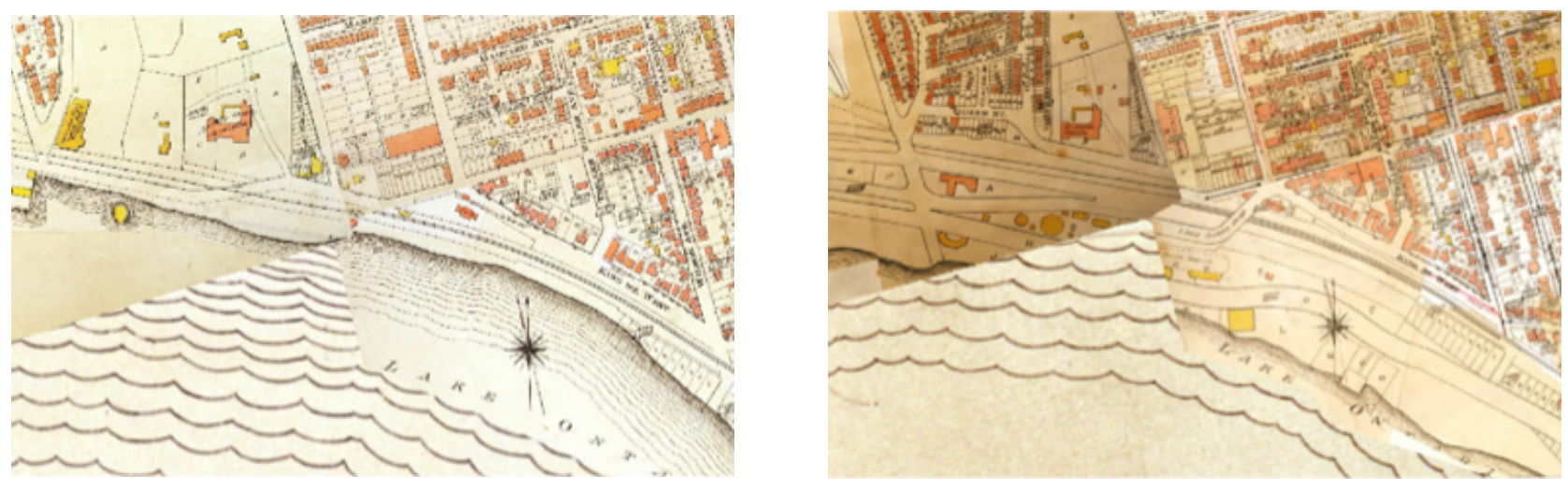

Figure 10 Goad Fire Insurance Map (1913)

along the Western Waterfront (see fig. 9 and fig. 10) (City of Toronto, 2009). In 1922, the Toronto Harbour Commissioners, also opened the Sunnyside Bathing Pavilion (see fig. 11) and the amusement park, on these newly created lands (Whitzman, 2009; City of Toronto Archives, n.d.c). The area had a famed two-mile long boardwalk, and a popular amusement park (City of Toronto Archives, n.d.c). Located just one kilometer southwest of Parkdale, Sunnyside was a popular destination within Toronto and contributed to the shoreline activity along Parkdale's southern edge. 


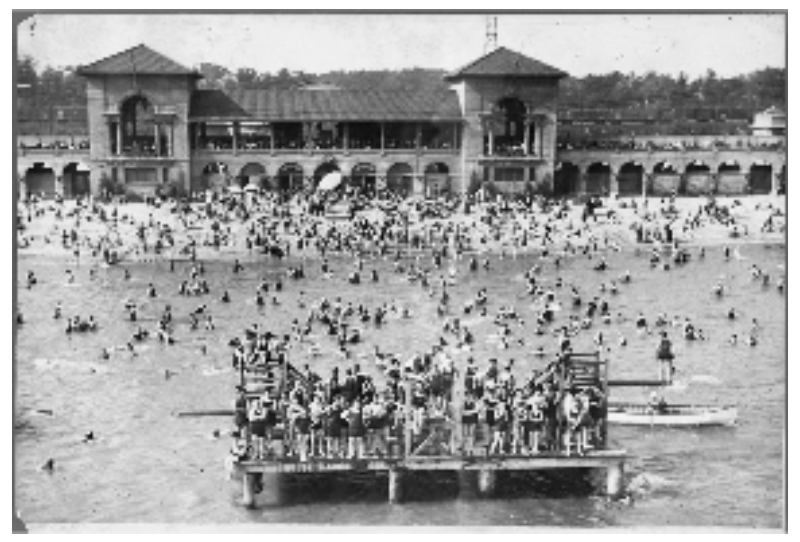

The popularity of the waterfront during this time, after the grade separation project, illustrates that even with a large infrastructural barrier, if there is lively activity along the waterfront paired with strong north-south connections, the waterfront can still attract visitors and locals alike.

Part of the Toronto Harbour Commissioners' 1912 Waterfront Development Plan was development of a waterfront boulevard to replace and extend the existing Lakeshore Road (City of Toronto Archives, n.d.d). Construction of the entire street was completed in 1930 (City of Toronto Archives, n.d.d). Lake Shore Boulevard West replaced Lakeshore Road from the former Queen Street West and King Street West Intersection to Mississauga. The boulevard was constructed on the newly constructed reclaimed land of Sunnyside Park. Lake Shore Boulevard and the boardwalk ran adjacent to one another (see fig. 12). The road, being surrounded by well programmed pedestrian walkways, did act as a major barrier to the lakeshore's activities. At the time the two lane road (with a parking lane on either side) served as an important access road to Sunnyside's activities (Toronto Public Library, 1934) and served as the primary entrance into the city. After World War II the number of private car owners increased drastically and traffic in Toronto increased dramatically. Specifically, the area along Lake Shore Boulevard between Sunnyside Park and the Exhibition 
grounds was notorious for bad traffic (City of Toronto Archives, n.d.d). These high congestion rates

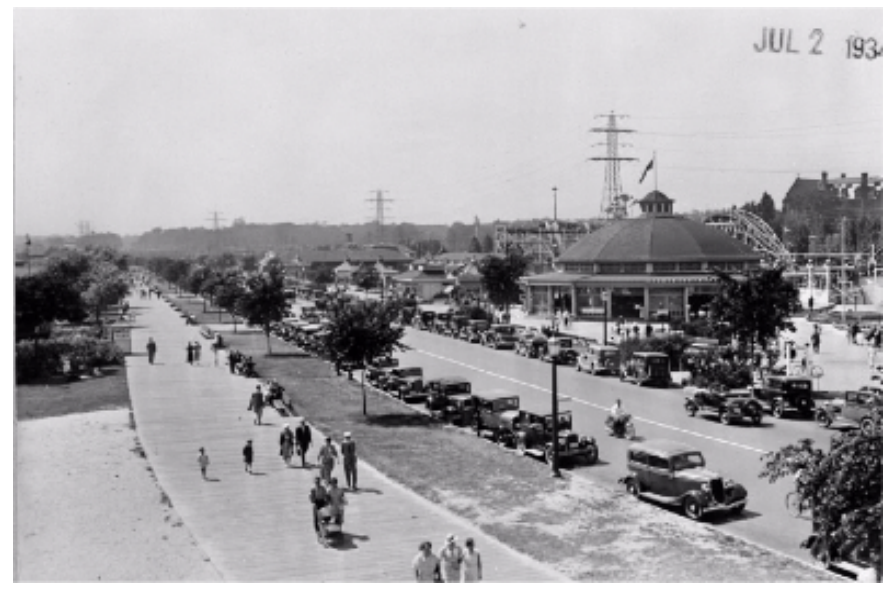

made the construction of a highway seem necessary to help relieve congestion (City of Toronto Archives, n.d.d). This time period marks a change in the perception of the waterfront as weekend destination to a conduit for automobile access into the city.

Parkdale's housing boom had been stalled since after World War I and the area was increasingly less attractive to wealthy and middle class residents (Whitzman, 2010). This waterfront area began to decline as the city of Toronto grew around the community to the north and west (Whitzman, 2010). With the proliferation of private automobile ownership, destinations further west of Toronto were now accessible. These areas were seen as more desirable as they provided the pastoral lifestyle that the increasingly urban Parkdale no longer accommodated. Family mansions were divided into boarding houses and small apartment buildings were built to accommodate the growing city (Whitzman, 20010). In conjunction with the rise in the private automobile, this area was no longer seen as a desirable community with waterfront amenities, but rather a conduit for automobiles to access downtown Toronto (Whitzman, 2010; City of Toronto, 2009). As a result, a new vision of the waterfront was conceived in 1939, with the creation of Metropolitan and the Western Waterfront was seen as part of a network of a large city-wide freeway system, a vision that 
lead to the construction of the Queensway and the Gardiner Expressway (City of Toronto, 2009; see fig. 13 and 14).
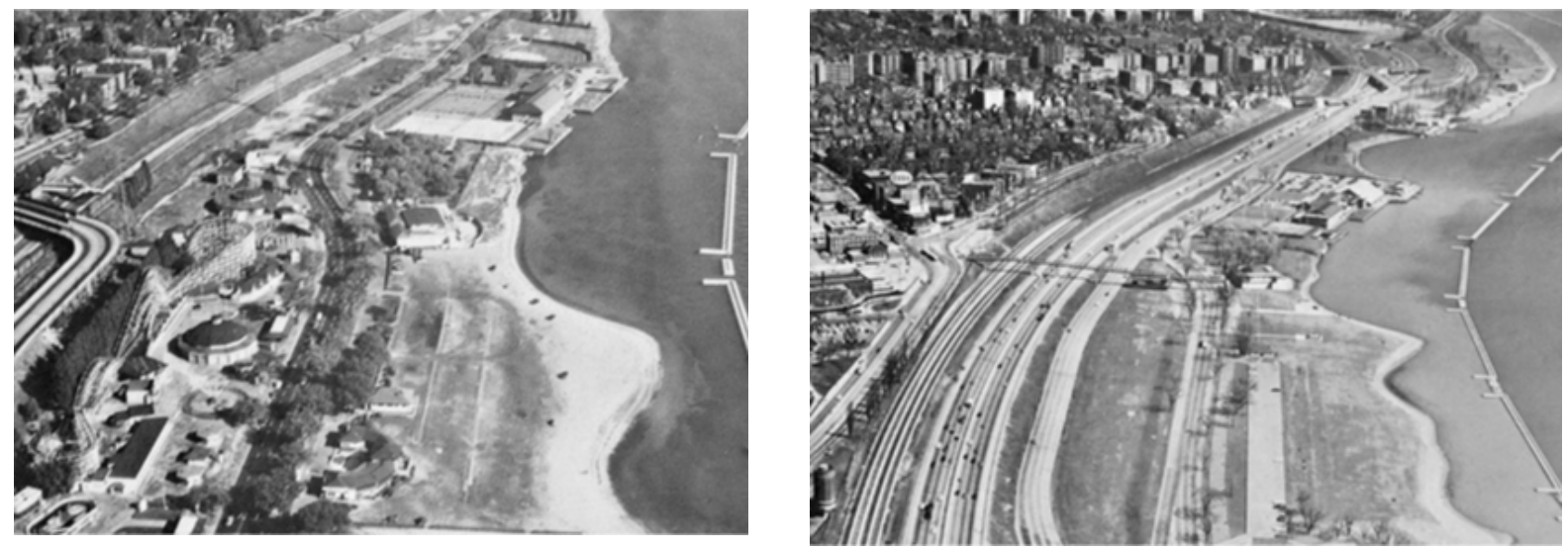

2.1.4 Gardiner Expressway

First proposed by the Toronto City Planning Board in 1947, the Gardiner Expressway was initially conceived as a waterfront highway from the Humber River to the Don River (Metro Archives, 1992). The original conception was a four-lane to six-lane expressway from the Humber River to Woodbine Ave. The City hired engineering firm Margison Babcock and Associated Limited and transportation engineer Norman D. Wilson to complete a functional study and determine the route planning (Reeves, 1993). The subsequent recommendation was to run an expressway south of the existing Lake Shore Boulevard (Reeves, 1993). This solution called for the demolishment of the existing Sunnyside Amusement Park and limited access to the lakeshore to four pedestrian overpasses between the Humber and Spencer Avenues (Reeves, 1993). This report illustrates the changing relationship to the waterfront. The waterfront was no longer seen as a recreational space but rather a conduit for the movement of cars. Norman D. Wilson later released a report distancing himself from the Margison recommendations and criticized the plan for destroying much of South Parkdale's parkland, he said:

The whole thesis of a waterfront is for public recreation and enjoyment, which has governed city policy for the past thirty years is discarded, and the improvements including tree growth, 
developed during that period at substantial cost are sacrificed (Toronto Lakeshore Expressway, 1954, as quoted in Reeves, 1993).

Wilson, recognizing the value of the waterfront parkland and Sunnyside Park, did not want to undo the planning efforts carried out by the Toronto Harbourfront Commissioners. Wilson criticized the plan, calling it "so contrary to the public interest, so devoid of city-planning forethought" (Municipality of Metropolitan Toronto, 1954). He also criticized the placement of the Gardiner in South Parkdale. The plan for the Gardiner Expressway called for the demolition of much of Parkdale's public space. Wilson wrote:

The South Parkdale Shore provides some of the most restful parkland in the Toronto area. It is completely severed from use by the Expressway with no indicated means of access or with no added provision for some in the estimates... There are 126 houses in south Parkdale south of the railway. The Margin Report of April proposes the demolition of all but 41 located on Dunn Avenue, Dominion Street and Empress Crescent. It also entails the complete destruction of all existing roads. The open area created is ostensibly parkland but this is a delusion as the areas enclosed within the ramp roads, though requiring park maintenance, must be kept closed to public use (Municipality of Metropolitan Toronto, 1954).

Although the shoreline route was moved north of Lakeshore Boulevard in the segment between Sunnyside and Jameson, many of Norman D. Wilson's concerns were not addressed. The construction of the Gardiner Expressway removed all of the existing roads south of the rail line and required the demolition of 170 homes in South Parkdale, more than the 80 anticipated, and the Sunnyside Amusement Park (Berjis and Panesar, 2011). Wilson’s predictions were correct, the 
parkland located between ramps were never used and remained isolated islands trapped between the loud and obtrusive car infrastructure.

This change in Parkdale's urban fabric can be seen in the figures 15, 16 and 17. Figure depicts the waterfront homes in Parkdale, surrounded by park and green space. Although infrastructural barriers still exist, including the railway and Lake Shore Boulevard, bridge connections over the railway and Lake Shore Boulevard were still present and shoreline activity still occurred. With the construction of the Gardiner, the 170 homes located south of the rail line in Parkdale were demolished (see figure 16).
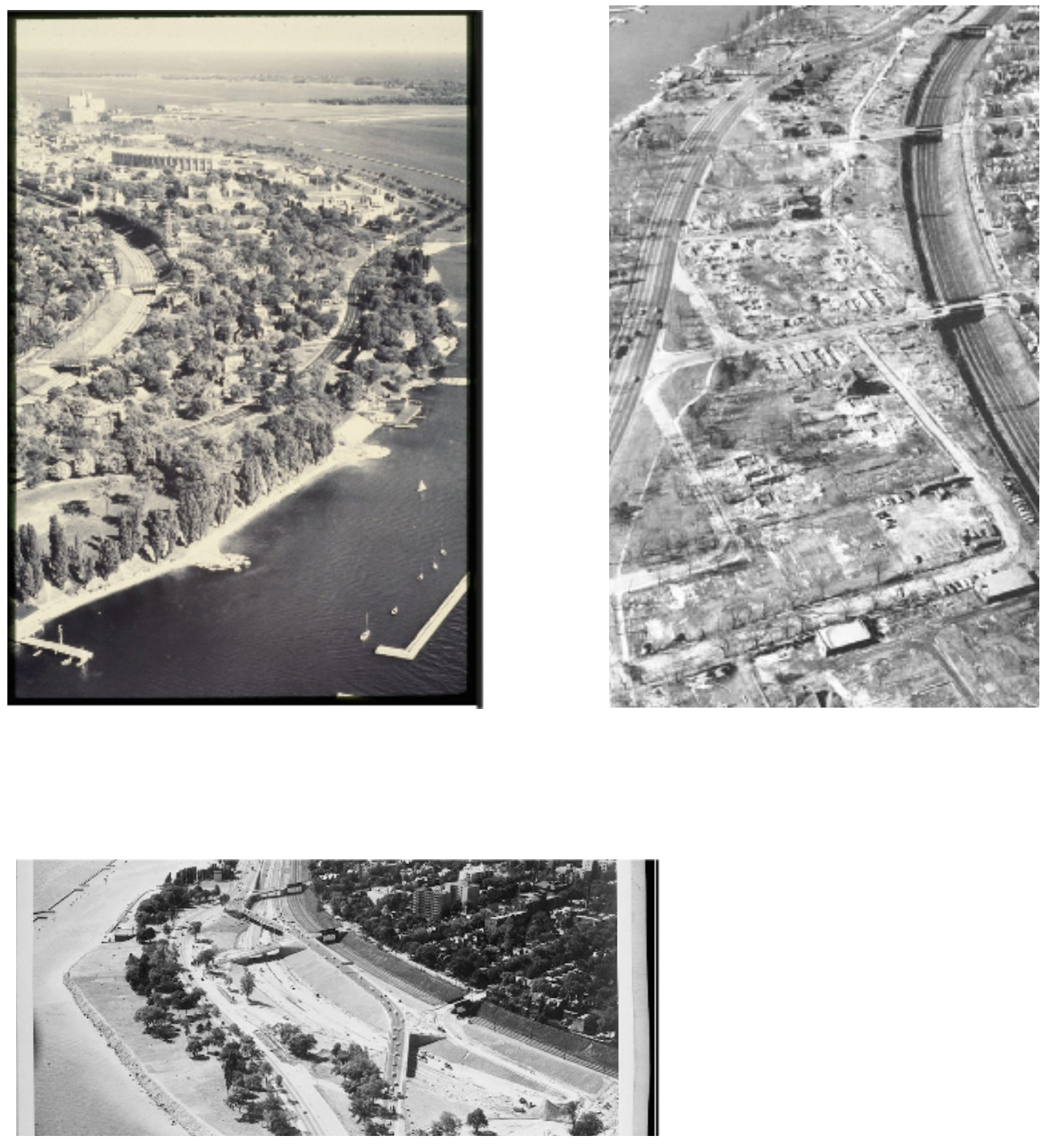
Construction of the expressway began in 1956 and was completed in segments, all of which were completed in 1965 (City of Toronto, 2009). The construction of the Gardiner was also paired with the expansion of Lake Shore Boulevard to six lanes in the area along the Western Waterfront (City of Toronto Archives, n.d.d). An interchange was built connecting the Gardiner to Jameson Avenue, with on ramps to Lake Shore Boulevard. The original rail line bridge connections remained, however they did not provide pedestrian connections to the waterfront (Municipality of Metropolitan Toronto, 1958). Since the construction of the Gardiner Expressway only one pedestrian crossing has been constructed in this area, along Jameson Ave. The construction of the Gardiner added another level of layer of infrastructure that further disconnected Parkdale residents and pedestrian access to the lakeshore. This added infrastructural layer occupies approximately 7.5 hectares of land along the strip of South Parkdale between Dowling and Dunn Avenue, which was previously home to residential uses and parkland.

The construction of the Gardiner has been attributed with additional changes in the built form of the area. After construction, the remaining mansions in Parkdale were converted to rooming houses and mansions along Jameson Avenue were replaced with high density apartment blocks (Manza, 2013). While the period after the World War I saw a flee of wealthy residents from the area, the period after the construction of the Gardiner saw a drastic change in the built form and the introduction of mid and high-rise apartment buildings. This change in built form was also accompanied by a change in local demographics and the once wealthy community became a home for people with mental illness, low-income residents and new immigrants.

The mid 1970s to the 1980s saw the closing of the Provincial Lunatic Asylum and deinstitutionalization of the nearby Queen Street Mental Health Centre. Many of the former patients established themselves in Parkdale, as many apartments and lower rent rooming houses were 
available to accommodate them. Thus, Parkdale has become a magnet for social and community services that provide for many lower income residents (Manza, 2013). The large apartment blocks and rooming housing also attracted low income residents, particularly newcomers. With $51 \%$ of its 2011 resident population born outside of Canada, South Parkdale is home to a diverse group of immigrants, with the major immigrant groups coming from the following countries: India, Philippines, Poland, China and other Asian Countries (City of Toronto, 2011). The high proportion of residents with mental illness and the diverse cultural backgrounds has created a community with a varied set of needs. This story of a changing waterfront and a changing community structure is not unfamiliar. Several cities have undergone similar changes and disconnection from the waterfront. Seattle, New York City, San Francisco and Barcelona are among the cities that have invested in large infrastructural projects, seeking to repair the broken connections and re-engage with the waterfront. The concept of waterfronts for enjoyment rather than industry has changed over the years. As cities attempt to brand themselves as world class cities, they recognize the need of great waterfronts to compete. 


\subsection{Disconnecting/Reconnecting to the Waterfront}

The growing importance of the waterfront can be seen in the proliferation of major waterfront redevelopment projects across the world, cities include Oslo, Hong Kong, Dubai, Glasgow, Rio de Janerio, New York, Seattle, San Francisco and Vancouver. These projects seek to renegotiate the relationship between waterfront landscapes and adjacent infrastructural systems. These efforts are being undertaken to undo the urban change that occurred when major transportation infrastructure was given priority and replaced public space on the waterfront. During the modernist period, urban waterfronts and cities experienced a period of economic decline and decentralization. As a result many urban waterfronts were seen as areas of urban decay (Gordon, 1996; Gospodini, 2002). Consequently, the waterfront became a less desirable place for development and public recreation (Gospodini, 2002). With the increase in private car ownership after the Second World War, and the subsequent process of suburbanization and decentralization, the public space on the waterfront was usurped by noxious uses including industrial and transportation (Gordon, 1997; Lehrer and Laidley, 2008). Several cities thus followed a similar process. The waterfront was increasingly taken away from public use and car transportation was prioritized. Subsequently the city began to develop away from the shoreline (Gospodini, 2002; Gordon, 1997).

Since the 1970s, waterfront redevelopment has begun in cities around the world, where waterfront industrial and transportation uses are transformed into commercial, residential and recreation areas (Bunce and Desfor, 2007; Gordon, 1997). Urban waterfront redevelopment is also tied to more recent trends in urban densification, which have intensified the development of the under-utilized areas along the waterfront (Gordon, 1997). The redevelopment of several of these 
cities has focused on improving access to the waterfront and on historical restoration (Gordon, 1996).

The City of Toronto is experiencing a similar desire to reconnect back to the waterfront evident through both the changing conversations regarding the role on transportation infrastructure in the downtown core and the establishment of Waterfront Toronto, a public organization established by the Government of Canada, the Province of Ontario and the City of Toronto with the mandate "to deliver a revitalized waterfront" (Waterfront Toronto, n.d.). Shortly after the Gardiner Expressway's development, suggestions have been given calling for its removal. In 1999, just 34 years after its completion, the Toronto City Council voted to demolish an elevated eastern section of the Gardiner (Waterfront Toronto, 2009). In 2001, the removal of the $1.3 \mathrm{~km}$ section of the Gardiner East between Bouchette Street and Leslie Street was complete (Waterfront Toronto, 2009). Again in 2001, the Toronto Waterfront Revitalization Task Force recommended that the remaining section of the elevated Gardiner be removed (Waterfront Toronto, 2009). These projects and proposals show a changing relationship between the City of Toronto and its waterfront and illustrate the City's desire to reconnect the waterfront.

Currently a variety of cities are making efforts to reconnect to the waterfront. These efforts follow a resurgent desire for walkability and desire to return the waterfront to public use and recreation. There is a current urban trend of using landscape urbanism to recreate the altered landscape, attempting to return it to a modified version of its original state. This design solution offers promise in correcting the disconnection created by the modification and addition of transportation infrastructure to the waterfront landscape. Parkdale, a neighbourhood that once had strong connection to the waterfront, has been the focus of several design projects that have transformed the waterfront area into public and recreational space. These projects, however, have 
failed to connect the community to the lakeshore. The infrastructural layers that were added along the waterfront radically altered the landscape and the community's relationship to the lake. The CN railway, the Gardiner Expressway and Lake Shore Boulevard are large infrastructural systems, whose presence in the landscape are substantial. In order to redefine the city's relationship to the waterfront these massive and essential infrastructural systems must be addressed in any design solutions. Before these systems were introduced, the community had a strong relationship to the lake. Recreating this landscape seems like a reasonable approach to improving and recreating Parkdale's relationship to the waterfront. Below I will explore methods of modifying the landscape through the lens of landscape urbanism. 


\subsection{Modifying the Landscape}

\subsubsection{Re-examining Transportation Infrastructure}

The introduction of the automobile drastically changed the construction of cities in North America. As a result of increase in private car ownership in the early twentieth century, there was a need to introduce infrastructure into the urban environment to accommodate high speed automobile circulation (Tatom, 2006; Mossop, 2006). Consequently, many of the urban projects of this era were primary focused on the movement of the car (Tatom, 2006). Many of the modernist proposals of this era, focused on separating functions, thus creating separate realms for the car and the pedestrian (Pollak, 2006). Famed architect Aldo Rossi was one of the first critics of the modern movement. He rejected the idea of functionalism in the design of the city because of "its denial of the complexity of the city" (Ellin, 1999, p. 24). It was also this type of modernist inspired planning that was vilified in Jane Jacob's seminal work, The Death and Life of Great American Cities. Rossi and Jacobs' critiques now dominate design discourse. Following this era of mono-functional planning came a consensus among planners that this strategy of separation produced and continues to produce sterile environments that destroy the public realm.

Many new urban visions were conceptualized during the postmodernist era in an effort to respond to these perceived failures of the modernist's visions of functionality (Ellin, 1999; Tatom, 2006). Several of these new planning theories, including New Urbanism, call for a return to the European planning ideals of the late-nineteenth century (Ellin, 1999). Embedded in many of these postmodern principles are pre-car planning ideals that still fails to acknowledge the complexity of the city and fails to adopt planning strategies that appropriately plan for the movement of the car at 
high speeds (Mossop, 2006). The need for high-speed circulation is an inevitable part of our cityscape and something that must be accommodated for in planning practice. While postmodernism responses acknowledge the failure of modernism to integrate multiple uses in the city, these critiques still fail to acknowledge the complexity of the city and fail to address the need to integrate pedestrian and vehicular movement. Weller (2006) suggests that "by virtue of economic rationalism and engineering, the infrastructural object or system in question in any development is given a kind of autonomous priority over the landscape (socio-ecological field) into which it is to be inserted" (Weller, 2006, p. 73). There is an urgent need to reexamine these infrastructural spaces and the priority given to these systems. As landscape architect, Elizabeth Mossop (2006) described:

This requires the rethinking of the mono-functional realm of infrastructural landscape and its rescue from the limbo of urban devastation to recognize its role as part of the formal inhabited city. Designers need to engage with this infrastructural landscape: mundane parking facilities, difficult spaces under elevated roads, complex transit interchanges, and landscapes generated by waste processes (p. 171).

It is important that planners and designers acknowledge auto-infrastructure as principle spaces within our city and design for these places. By re-examining and engaging with infrastructural landscapes, rather than a preoccupation with pre-car urbanism fantasies, planners and designers can begin to engage with these spaces and integrate these important and inevitable parts of the city.

"Highways are public space writ large, in the metropolitan reach of their network as well as their sheer size" (Tatom, 2006, p. 181). Car and rail infrastructure has a substantial and essential presence in the city, yet planners and designers often neglect to think of these systems as public space. Not only are these networks not thought of as public space but the spaces surrounding them are also abandoned as well. This abandonment of public space is evident in Parkdale, where 
approximately 30 hectares of open space located between transportation infrastructures has been left undeveloped and unexplored.

Road typologies have been distinguished in the past by their relationship to their surroundings. This was determined by their degree of specialization so that most highly specialized freeways and expressways had almost no relationship to their environment, being corridors for the transit of automobiles only (Mossop, 2006, p. 173).

Highways not only occupy the space that they sit, but their physical presence is ever reaching and design attempt to separate their uses leaves the areas surrounding the highways and roadways as derelict spaces. Highways and roads represent an opportunity for designers to renegotiate how the city orders infrastructure, "by unsealing these spaces we can integrate the road network and develop a relationship to its environment, we can also develop the public space around the road and reclaim it.” (Mossop, 2006, p. 172)

Busquets (2006) outlines a trend in urban projects, which he terms 'Reconfigured Surfaces', where "geographies previously labeled 'derelict' or 'terrain vague' are being reconfigured into positive ones that add to the overall value of the city" (Busquets, 2006, p. 109). These efforts illustrate the reordering of the city's infrastructural spaces and integration of public spaces through good design. Projects that begin to integrate public space and design are illustrating compelling alternatives to removing, burying or replacing transportation infrastructure. Large in scale, transportation infrastructure is difficult and costly to relocate, therefore modest infrastructural interventions offer a promising option to reimagine urban mobility and "can give historical centres renewed vitality and improve outlying districts more effectively than can costly restructuring operations (Busquets, 2006, p. 137). As poignantly stated by international architect, Richard Rogers, "we have to recognize the fact that 90 percent of what will exist twenty years from how has already 
been built” (Richard Rogers, as quoted in Allen \& McQuade, 2011, p. 254). Reconfigured surfaces arm us with strategies for intervening with these structures that have already built and will continue to occupy our space for years to come.

As transportation infrastructure is stationary, strategies of design that learn to integrate transportation infrastructure with additional uses are of particular importance. Removing or altering is costly and perhaps impossible, modifying the landscape can present the opportunity to alter the landscape while still allowing for use of the current infrastructure. Relocating infrastructure not only requires large investments but also requires available land, which is often not present in dense urban centres. Alternatives to restructuring and replacing need to be considered. Landscape urbanism emerged in the 1990s to address this reordering (Waldheim, 2006). Landscape urbanism, is an approach to urban planning that uses landscape, rather than the built form, as the driver of design. This approach seems appropriate in the context of Parkdale's waterfront, where public space and landscape played a vital role and where meaningful landscape was removed through the addition of roadways.

Despite the impact of their implementation, Lake Shore Boulevard and the Gardiner Expressway represent essential local and regional transportation systems for the City of Toronto. While their construction may have been inappropriately planned, these roadways are now vital pieces of Toronto's road network. Removing, relocating or burying these roads does not represent viable options given the spatial and economic constraints in the City of Toronto. Integrating and reclaiming the spaces surrounding Lake Shore Boulevard and the Gardiner Expressway represent promising design options to reclaim these forgotten spaces and create a more judicious use of space. In an area bounded by natural elements, using landscape as the driver of planning and design offers a more meaningful connection to the landscape. 


\subsubsection{Landscape Urbanism to Reimagine Transportation Infrastructure}

Landscape urbanism, a planning approach that relies on the expertise of architecture, landscape architecture, urban design and planning, calls for landscape to replace architecture as the foundation of urban planning (Waldheim, 2006; Corner, 2006; Steiner, 2011). The practice relies on collaboration between these professions to take the methods and practices of landscape architecture and expand its scope beyond the design of parks to the planning of larger urban sites (Allen and McQuade, 2011; Wall, 1999; Steiner, 2011). Landscape urbanism differs from traditional urbanism, where some structure (built form and infrastructure) directed the construction of the city (Steiner, 2011). It differs from other contemporary planning approaches like New Urbanism, which promotes walkable mixed-use developments. These planning approaches still use the built form as the driver of design. Landscape urbanism places landscape at the forefront of design.

Landscape urbanism originated as part of the "postmodernism critique of modernist architecture and planning" (Waldheim, 2006, p. 38). Among these criticisms were modernist architecture's inability to "produce a 'meaningful' or 'livable' public realm, for its failure to come to terms with the city as an historical construction of collective consciousness, and for its inability to communicate with multiple audiences" (Waldheim, 2006, p. 38). Architecture, the foundation of urban design, was criticized for its lack of ability to appropriately solve the complex problems of the contemporary city's urban condition (Waldheim, 2006). Landscape urbanism thus provided a compelling alternative for restructuring the city as its multidisciplinary approach offered a more comprehensive approach to address the city's complex problems (Waldheim, 2006, p. 37).

The emergence of this new discipline illustrates an increased understanding of landscape as a complex system that can work to reorganize urban form. It no longer examines landscape solely in reference to its 'pastoral innocence' but rather looks to landscape for its ability to act as a 
"connective tissue that organizes not only objects and spaces but also the dynamic processes and vents that move through them" (Wall, 1999, p. 233). Through this emerging theory, landscape is given as new tool for the urban design and planning disciplines.

As landscape urbanism evolved as a theory, it began to look at using landscape to address the more complex urban systems, like transportation infrastructure.

The intellectual promise of landscape urbanism to integrate the conceptual fields of landscape architecture, civil engineering, and architecture for the design of the public realm places urban highways squarely within its purview (Tatom, 2006, p. 181).

Here we see landscape urbanists call for the reevaluation of transportation infrastructure through the lens of landscape urbanism. Landscape urbanism is a compelling approach to addressing the disconnections in waterfront landscapes like Parkdale. Using landscape as a tool provides the opportunity to integrate the spaces currently locked between the Gardiner Expressway, the rail line and Lake Shore Boulevard and reclaim approximately 30 hectares of unused space that lie between these transportation systems.

With the advent of the car, cities restructured their infrastructure systems and developed comprehensive road networks within and extending outwards from the city centre. Following the modernist movement, postmodernist planning began to view this transportation infrastructure as dividing the city. Integrating public space into these transportation systems offers a solution to address these presently dividing structures (Waldheim, 2006). Landscape architect, Richard Weller describes how landscape urbanism offers a compelling promise of remediating and addressing the mono-functional car infrastructure left behind from the modernist planning movement:

The inclusion of multiple programs within the right of way of the intervention itself through a careful design of the section ensures that the pedestrian and the automobile driver receive 
equal consideration while maximizing the use of public resources. In addition, it reestablishes a morphological continuity of the urban fabric that rapidly overcomes the social and physical disruption of the often violent construction effort (Tatom, 2006, p. 192).

While many current planning and design practices favour separating pedestrians from high speed roadways, several planners and landscape urbanists are providing successful examples that illustrate the integration of these uses can support "regeneration of an isolate site, whose derelict conditions has been produced, in many cases, by its position between radically different scales." (Pollak, 2006, p. 133). Current planning practices often neglect the importance of the integration of landscape into our city systems. Planning should think of landscape as more than just parks. Just as postmodernism planning brought the fields of architecture and planning together, landscape urbanism's approach of integrating the fields of landscape architecture, architecture and planning represents the new way forward.

Although the integration of public spaces into roadway infrastructure offers a compelling solution to the reordering of the city, in reaction to modernist planning and the influx of major highways through the city, postmodernist planning has favored burying the road (Ellin, 1999; Mossop, 2006). While this is appropriate in select planning projects, it is not appropriate for all urban contexts. Few cities have the high densities required to make this large scale project feasible (Mossop, 2006, p. 173). An expensive transportation tunnel project hardly seems feasible in Toronto, a city that still offers developable land and is increasingly experiencing fiscal constraints from the municipal level. Landscape urbanism offers a promising solution for interventions in transportation infrastructure that allows an increased use of the public realm, without the extreme costs associated with moving high speed automobile circulation to a subterranean underworld. These complex infrastructural systems however require more advanced forms of landscape 
urbanism to develop a design solution to address these spaces. Design professionals therefore turned to landscape architecture's practices of folding, surface manipulations, and the creation of artificial terrains (Allen, 2011, p. 24). These practices are now occupying a new domain of architecture, termed landform building.

\subsubsection{Using Landscape Urbanism - Landform Building}

The rise of landform building followed the emergence of landscape urbanism is seen by the increased focus on the subject both in the field of academia and professional practice. This is seen by the conference held by the School of Architecture at Princeton University on landform building and the subsequent book, Landform Building: Architecture's New Terrain. Both the conference and the text explore ways in which landscape and the landform manifest in contemporary architectural practice. Landform building attempts to explore how landscape architecture can inform architectural practice, and seeks to identify new design techniques, strategies and technical problems (Allen, 2011). Allen (2011) describes landform building as:

Green roofs, artificial mountains and geological forms; buildings you can walk on or over; networks of ramps and warped surfaces; buildings that carve into the ground or landscapes lifted high into the air: all these are commonplace in architecture today. New technologies, new design techniques and a demand for enhanced environmental performance have provoked a re-consideration of architecture's traditional relationship to the ground. (Allen, 2011, p. xi)

The book explores the use of landscape within the discipline of architecture and how the relationship between the two disciplines has evolved over the years, including how landscape urbanism has changed the discipline of architecture and its traditional relationship to urban environment. Cities are becoming more complex systems, therefore there is a need to renegotiate 
the city's infrastructure and public spaces, and include the role landscape plays within these systems (Allen, 2011, p. 225). This is where landform building steps in, "Landform building proposes that architecture, rather than occupying a given landscape, works to construct the site itself' (Allen, 2011, p. 196). The waterfront landscape of Parkdale presents many challenges including an undulating topography and a complex infrastructural system. Landform building offers the appropriate tools needed to 'construct the site' and develop a landscape structure that reintegrates the space into the city fabric.

Landform building offers many tools that can be used to integrate transportation infrastructure beyond the simple introduction of park space. It offers techniques for developing megastructures, (i.e. large scale buildings constructed to look like other earth forms), green roofs, surface manipulation, constructed land and semi-subterranean structures, to name a few. These tools can be used to address the complex systems and multiple functions that roads are required to perform (Mossop, 2006). "In this new planning era roads are expected to fulfill the requirements of public space and must be connected to other functioning urban systems of public transit, pedestrian movement, water management, economic development, public facilities, and ecological systems” (Mossop, 2006, p. 174). Landform building offers the new design approaches needed to supply these multiple functions. This new practice not only recognizes new techniques but also recognizes that architecture can expand the scale of design. Expanding the scope of design beyond the building to the landscape it inhabits gives the designer "new programmatic potentials, new relationships to the site, and new technical challenges" (Allen, 2011, p. 225). This work makes infrastructure and their adjacent public space projects new possibilities for design. Infrastructure does not have to remain in its current mono-functional design domain, the expanded scope of landform building activates new possibilities for infrastructural design. 
Previous roadway infrastructure has been poorly served by design and often the design solution to remediate its presence in the city is to move vehicles below ground, to single use tunnels (Mossop, 2006). Landform building gives us the techniques to address these issues and integrate transportation infrastructure with landform building design techniques that do not involve burying. Landform building presents the opportunity to explore alternatives to the tunnel to reinvent these spaces. It offers the compelling promise of integrating public and transportation infrastructure space through new tools and new forms of connectivity. As described by Allen (2011), "architecture, which has traditionally been associated with the vertical plane and boundary partitions, dissolves into an extensive, horizontal field of interconnected surfaces" (p. 23)

\subsubsection{Reconstruction}

Landform building and landscape urbanism offer new tools to designers to drastically change the landscape of the city. Architects can reconstruct nature through buildings and structures that take on forms of mountains, natural topography, and other earth forms. (Gissen, 2011). With these new techniques come the possibility that urban projects may not integrate effectively into the surrounding context. Girot (2006) notes that despite the design talents present in urban planning projects, a project may fail to integrate into its surrounding context if it the project fails to create cohesion with its surrounding context. Projects can be "oblivious to the sensitive physical and visual realms of landscape" (Girot, 2006, p. 92). New design practices that take into the account the history of place, integrate more effectively into the urban environment (Girot, 2006). Through reconstruction, the integration of reconstructed historical topographies, historical natural landscapes can be placed into the contemporary city to help develop high quality design that integrates new projects effectively with the surrounding context (Gissen, 2011). Included in the effort of reconstruction is the process of the rebuilding of lost nature with architecture and landscape urbanism techniques (Gissen, 2011). Recent landscape urbanists and those using the techniques of 
landform building have started to reconstruct nature representing the historical aspects of the past, through the reconstruction of topography and nature (Gissen, 2011). Adding these historical reconstructions of nature and topographic to help create a "hybrid of nature and landscape" (p. 457), or more specifically a hybrid of infrastructure and landscape.

Landform building techniques offer the opportunity to rebuild the lost nature that was destroyed along with the construction of the Gardiner Expressway. Although it cannot be completely reconstructed, the historical connection to the waterfront and the park space that was previously present in South Parkdale represents successful components of Parkdale history. Reconstructing the natural topography of Parkdale, recreating the historical north/south waterfront connections and adding parkland in Parkdale will add the elements which have already proven to be successful in this community and will create a hybrid of infrastructure and landscape.

Landform building techniques offer solutions to stitch infrastructure into the urban landscape. There are several precedents worldwide that illustrate how to integrate these obtrusive forms into the urban fabric, these include: Seattle’s Olympic Park, Barcelona's Ronda Litoral, Boston's Central Artery/Tunnel project. These three international case precedents represent three different options for overcoming infrastructure barriers with land islands from Parkdale to the Western Toronto Waterfront. The three options explore various scales of developing connections over infrastructure and include interventions with ramps, bridged structures and tunnels. 
2.4 International Case Precedents

2.4.1 Olympic Sculpture Park, Seattle
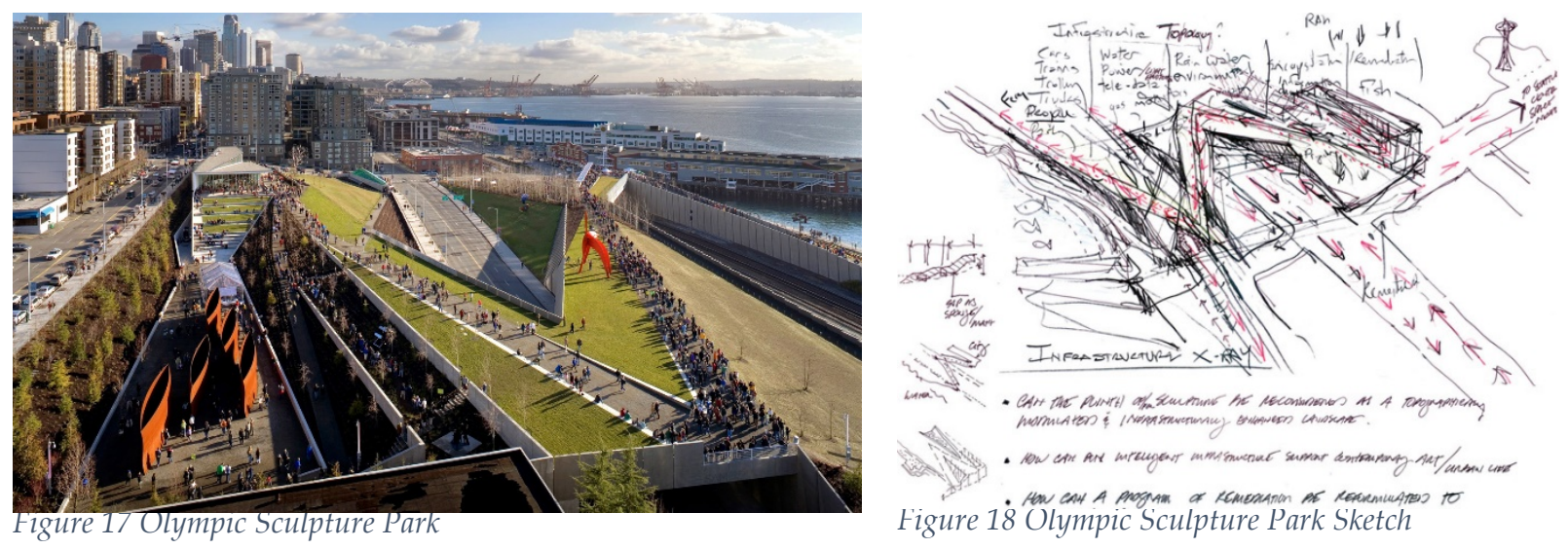

Olympic Sculpture Park is an excellent example of overcoming infrastructure to create a cohesive urban fabric that links to the waterfront. Cut off from the waterfront by the four-lane road and an active rail line, the eastern side of the site was connected to the waterfront using constructed topography and a network of ramps and warped surface (Deitz 2005; Busquets, 2006)

The site occupies 8.5 acres in a vibrant downtown neighbourhood (Pearson, 2007). While the site served as a fuel storage and transfer facility for Union Oil of California for the majority of the 20th century, it was left vacant in the 1970s (Pearson, 2007, Diez, 2005). Despite pressures from developers to purchase the site for the construction of condos, the Seattle Art Museum purchased the site for $\$ 17$ million with the vision to create an outdoor venue for showcasing sculpture art (Pearson, 2007). The Seattle Art Museum saw an opportunity to develop much needed green space in the city and construct a new structure that presented "landscape as art" (Weiss/Manfredi, 2015). Weiss/Manfredi, a self-described architecture/landscape/urbanism firm, won the bid with their design to reconstruct the natural topography to navigate to 40 foot drop within the site (Allen, 2011). 
The $\$ 85$ million dollar design focused on constructing new topography to link the eastern boundary of the site to the western waterfront (Pearson, 2007). The constructed topography would create a park and a network of ramps that would zigzag and connect the city to the waterfront, over an active rail line and a four-lane road (Pearson, 2007). Weiss/Mandredi "decided at the very beginning that the trains and cars moving through the landscape would be important elements in the park” (Pearson, 2007) 'We weren't going to be ashamed of them,' says Mandredi” (Pearson, 2007). The park's integration of transportation infrastructure is hailed a success in the design community. The park, originally designed to be an art attraction has unexpectedly been adopted by the fitness community as local runners and walkers frequently use the space.

Weiss/Manfedri's Olympic Sculpture Park illustrates how challenging infrastructure can be integrated into the design and the urban fabric can be repaired as the city is stitched together using the principles of landform building. This project reclaims the forgotten cityscape and creates a public domain, repairs the urban fabric and develops new connections to the waterfront (Allen, 2011).

\subsubsection{Ronda Litoral, Barcelona}

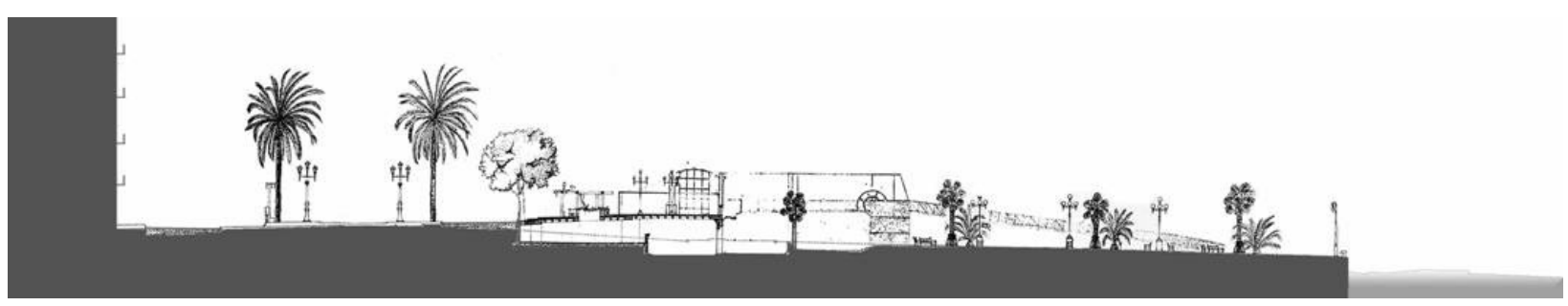

Following a similar pattern to other modern cities, Barcelona was disconnected from its waterfront with the construction of the B-10 highway (Busquets, 2005a). With the construction of 
the highway the city turned its back on the waterfront and developed an orientation away from the seafront (Busquets, 2005a). The city's disconnection from the waterfront continued with the construction of a railway line, which contributed to the obvious division between the waterfront and the historic city (Busquets, 2005a). With the winning of the 1992 Olympic Bid, Barcelona developed an aggressive urban development program, with a specific focus on providing new access to the waterfront (Busquets, 2005b). A variety of infrastructural interventions transformed Barcelona's waterfront and improved access to the sea despite the barriers presented by the highway (Busquets, 2005b).

Of particular interest is the section of Moll de la Fusta along the Ronda Litoral Ring Road. The Ronda Litoral is a major urban highway that runs along the rail line (Busquets, 2005a). At strategic places, structures were bridged over the road to provide access to the waterfront. This linkage was created by developing a two-level section with a false tunnel over the railway line and roadway (Busquets, 2005a). With the lower level restricted for rail and car use, the upper level allowed for pedestrian access from this historic waterfront to the newly developed waterfront and port.

The project of Moll de la Fusta along the Ronda Litoral Road, illustrates how reordering infrastructural spaces can provide additional public spaces and pedestrian access. While similar to the Olympic Sculpture Park, the section of Moll de Fusta shows how larger scale constructions can develop strong pedestrian connections, while maintaining the volumes needed for the circulation of vehicles. 


\subsubsection{Central Artery/Tunnel Project, Boston}

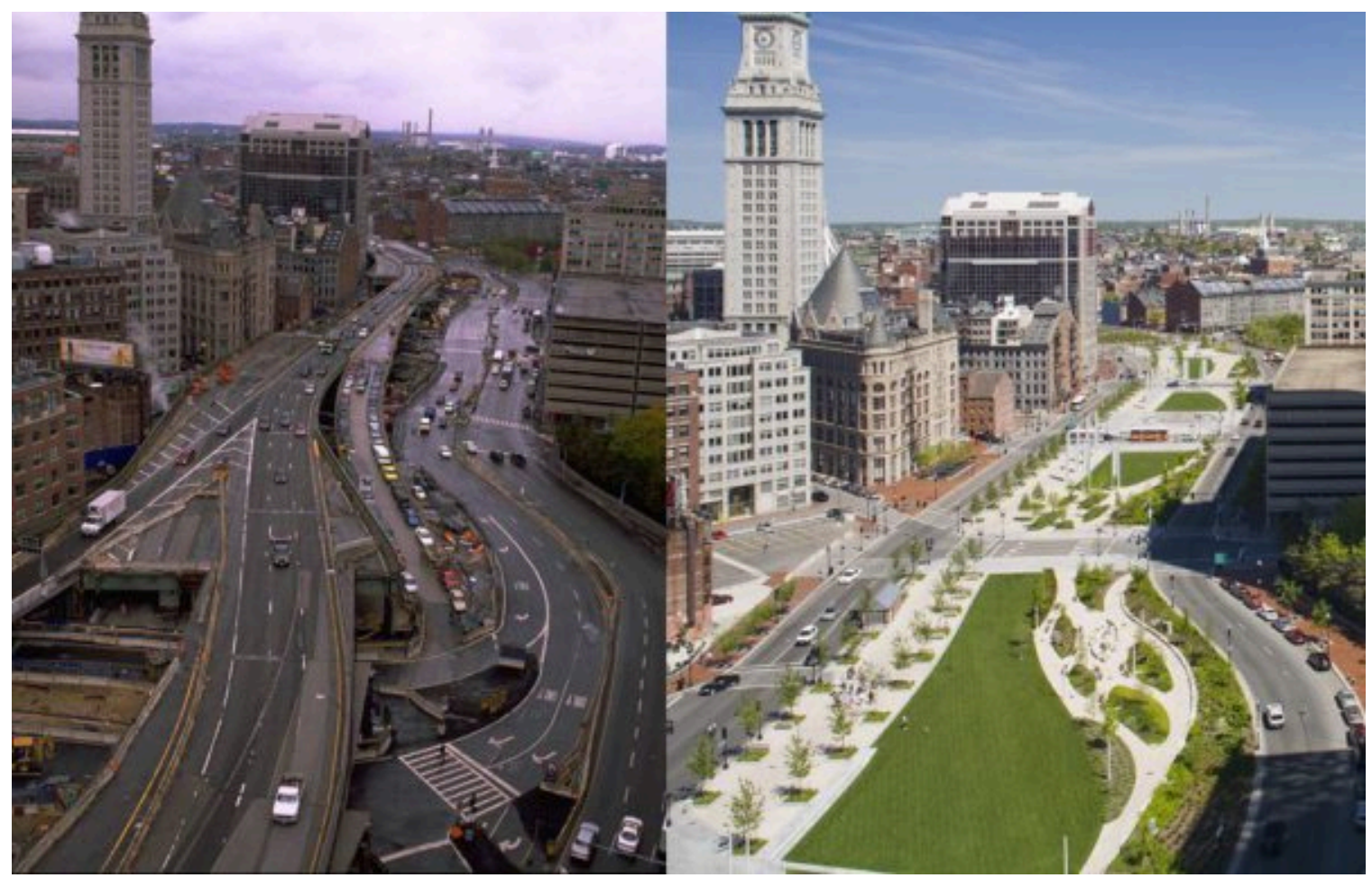

Figure 20 Downtown Boston Before and After the Boston Big Dig

The Central Artery/Tunnel project, commonly known as the Big Dig, is a downtown highway removal project that replaced the crumbling Central Artery at the centre of downtown Boston, with an underground Tunnel (Tajima, 2003; Mass Dot, n.d.). Built in the 1950s, "the original expressway, a 40-foot high wall of concrete and steel, cut off Boston from its historic waterfront and displaced 20,000 residents" (Fein, 2011, p. 4). The goals of the project were to replace crumbling infrastructure, reduce traffic congestion in downtown, reconnect the city to the waterfront, create new parkland and finalize the link in the Seattle-to-Boston I-90 superhighway (Fein, 2011). 
In 1991, construction began to replace the six-lane elevated expressway with a 7.5-mile system of underground expressways, eight-to-ten-lanes wide, adjoining ramps and bridges linking to existing roads (Fein, 2011). With original cost estimates at $\$ 15$ billion the project is estimated to have surpassed $\$ 24$ billion in total spending, making it the largest public works project in US history (Tajima, 2003; The Associated Press, 2012). The project create 40 acres of land in downtown Boston, with seventy-five percent (30 acres) of the newly created land developed as open space and twenty-five percent of the land was sold and developed as retail, commercial, and housing (Tajima, 2003; Mass Dot, n.d.). This network of newly created public space, retail, commercial and residential land and restored surface streets were constructed in an effort to stitch together the urban fabric that was divided by the original Central Artery. Some critics of the project however suggest that there is too much green space in the project, resulting in an unactivated park space and a missed opportunity to capture additional funds from land development and sale.

While the Central Artery/Tunnel project was plagued with costly delays and project overcharges, the project provides many lessons to be learned of how to reclaim infrastructural spaces, while creating new public space. Through these reinterpretations of infrastructure, there is the opportunity to augment and create new opportunities for public realm in Parkdale. Landform buildings techniques can also be applied to capture additional land for development. The project serves as an important reminder that while an attractive solution, burying roadway infrastructure is an expensive option with many unforeseen costs. The project also demonstrates the importance of balancing retail and commercial uses with park space. Retail and commercial uses present the opportunity to not only provide street life and encourage pedestrian traffic in the area but also provides an important revenue tool that needs to be used appropriately. 


\subsection{Research Methodology}

This design project seeks to identify an appropriate design connection along the Western Toronto Waterfront. In this section four methods are introduced. The methods seek to identify a strategic area for design intervention, assess the appropriateness of different scales of intervention and inform the overall design process. Method one highlights the criteria for the definition of neighbourhood boundaries. Method two outlines a calculation for determining park space within a neighbourhood and city. This calculation with be used to help determine the community need for additional park space within the neighbourhood of Parkdale and overall in the City of Toronto. Method three describes the process for creating a simple topographic model to analyze scale and apply case precedents. Lastly, method four outlines the criteria and collection of data use on a site visit to Olympic Sculpture Park.

\subsection{Method 1: Identifying Neighbourhood Boundaries}

The City of Toronto has identified and named 140 neighbourhood within its boundaries. These neighbourhood boundaries are primarily based on the Statistics Canada census tracts for the "purposes of data presentation and reporting" (City of Toronto, n.d.a). The neighbourhood boundaries were constructed for data comparison in areas with like population and demographics and service levels, however, they do not give an accurate representation of a resident's perception of 'neighbourhood'. The Ottawa Neighbourhood Study (ONS) notes the importance of recognizing physical barriers as strong neighbourhood boundaries. The ONS identifies neighbourhood boundaries as being delineated by a combination of social and physical boundaries and notes that physical barriers, including highways, act as strong neighbourhood boundaries (Ontario Neighbourhood Survey, n.d.). 
Identifying an appropriate neighbourhood boundary is important for determining resources and identifying deficiencies in resources within a community. City of Toronto neighbourhood maps were gathered and site visits were conducted to identify appropriate boundaries. Site visits were conducted to identify the physical barriers boundaries of Parkdale. Photos were taken along the Parkdale southern edge to document and identify potential pedestrian barrier of highways in this area. These physical barriers were documented and used in combination with the City of Toronto neighbourhood maps to identify the neighbourhood boundaries of Parkdale. Results from method one are presented in the following section.

\subsection{Method 2: Parkdale Park Space Calculation}

Calculating the percentage of a neighbourhood area used for park space provides an insight into the provision and allocation of park space. Acres of parkland as a percentage of city area is a commonly used calculation used to illustrate the provision of parkland within a city (Trust for Public Land). Calculating the percentage of Parkland for the City of Toronto and neighbourhoods within Parkdale will allow for comparisons with other cities and will provide insight into park space standards and the identification of a potential lack of resources

Using ArcGIS, maps of the City of Toronto park space and neighbourhoods were created to calculate the proportion of park space within each City of Toronto neighbourhood and determine the potential need for additional park space within Parkdale. First, data was collected from the City of Toronto Open Data Catalogue to map City of Toronto defined neighbourhoods and park space (see fig. 22). Next, the areas of the City of Toronto defined neighbourhoods and park space were calculated (see fig. 23). Lastly, a calculation was conducted, dividing the neighbourhood area from the total park space within the respective neighbourhood boundaries (see appendix A). Results from method two are presented in the following section. 

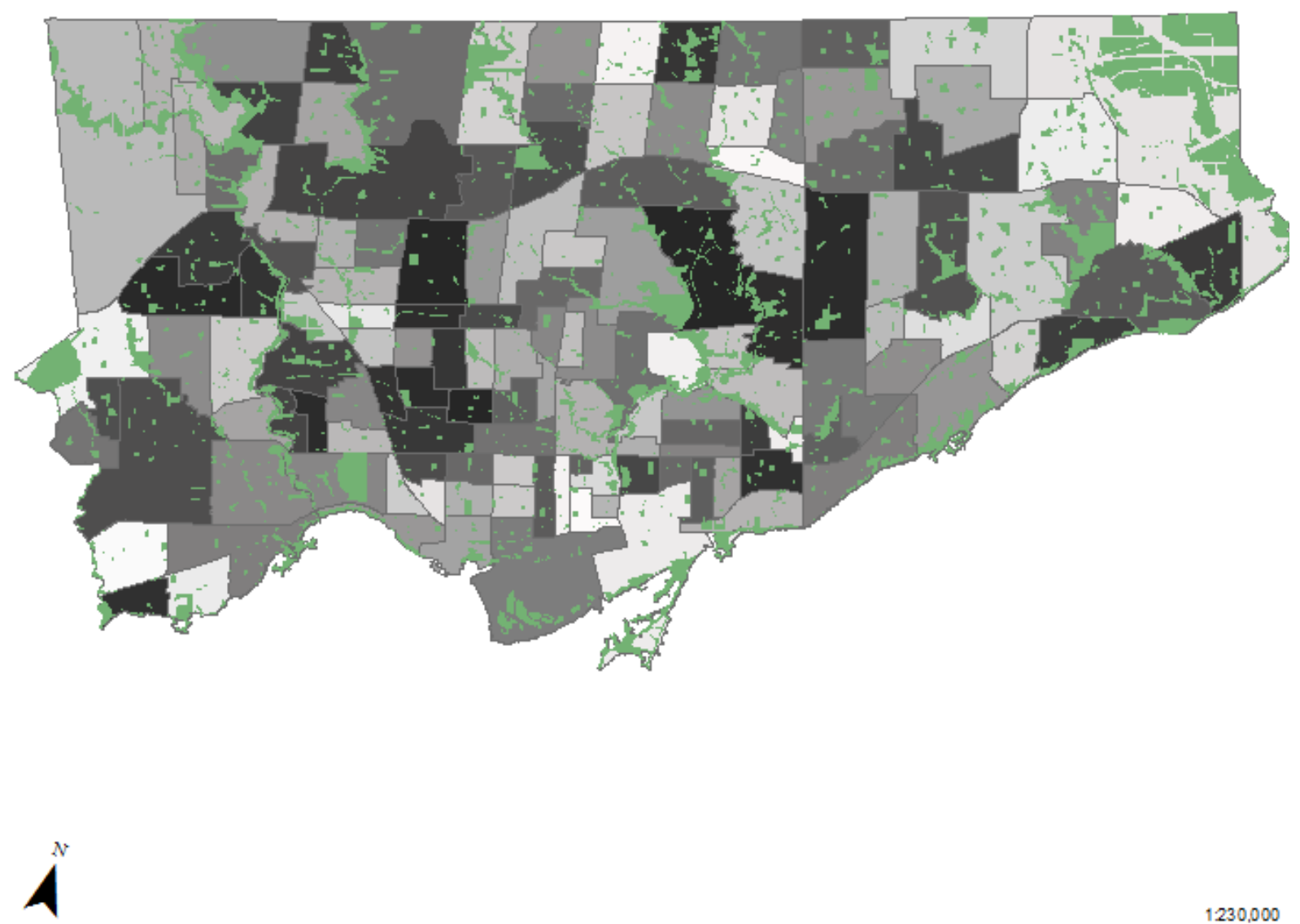

Figure 21 Mapped Neighbourhoods and Park Space in Toronto

\begin{tabular}{|c|c|c|c|c|c|c|c|c|c|}
\hline Table & & & & & & & & & $x$ \\
\hline :号・|昆 & 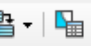 & T. & $x$ & & & & & & \\
\hline CITY_GREE & EN_SPAC & E selection & PARKDALE & & & & & & $x$ \\
\hline FID & Shape & GEO_ID & TYPE_DESC & SCODE_NAME & LCODE_NAME & NAME & OBJECTID & area_ha & \\
\hline 928 & \begin{tabular}{|l|} 
Polygon \\
\end{tabular} & 2585175 & PARK & & 1087 & MARILYN BELL PARK & 16206097 & 7.574726 & \\
\hline $961 \mathrm{~F}$ & Polygon & 2585174 & PARK & & 1235 & LAKESHORE BOULEVARD PARKLANDS & 16210561 & 4.369321 & \\
\hline $1006 \mathrm{~F}$ & Polygon & 2585171 & PARK & & 0530 & SIR CASIMIR GZOWSKI PARK & 16210209 & 12.878782 & \\
\hline $1088 \mathrm{~F}$ & Polygon & 2585170 & PARK & & 1235 & LAKESHORE BOULEVARD PARKLANDS & 16209969 & 0.890448 & \\
\hline $1510 \mathrm{~F}$ & Polygon & 2585171 & PARK & & 2049 & BUDAPEST PARK & 16210145 & 6.322254 & \\
\hline 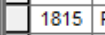 & Polygon & 2585170 & PARK & & 1235 & LAKESHORE BOULEVARD PARKLANDS & 16210001 & 2.247204 & \\
\hline $1950 \mathrm{~F}$ & Polygon & 2585170 & PARK & & 1235 & LAKESHORE BOULEVARD PARKLANDS & 16210017 & 1.449834 & \\
\hline 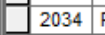 & Polygon & 2585171 & PARK & & 0441 & SUNNYSIDE PARK & 16210097 & 3.850929 & \\
\hline 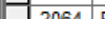 & & 3202172 & DADK & & 1222 & | I AKeCU & 192111117 & 1 c11221 & \\
\hline
\end{tabular}




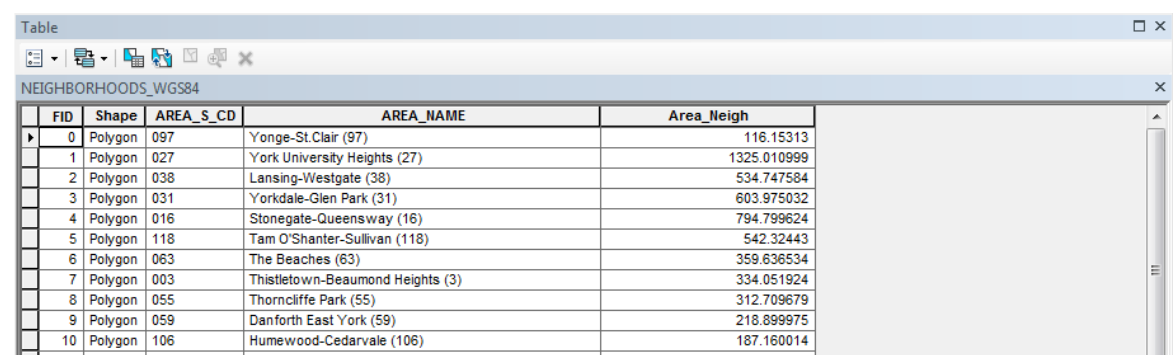

Figure 22 Calculated Park Space and Neighbourhood Space

3.3 Method 3: Site Modeling, Identifying and Applying Case Precedents

A rough study model was constructed of a section of the Western Toronto Waterfront to examine the possibility of a pedestrian connection in the area. Site modeling provides understanding of the natural topographic form and scale of a selected site. The model was created at a 1:1,500 scale using $1 \mathrm{~cm}$ thick millboard. A larger scale was used to allow for the examination of several possible areas for connection.

The model was constructed based on the topography of the area, the road network was also created as a supporting piece to the model. The road network helped to identify important streets, the possible connection and the surrounding topography.

An area was selected in the community of Parkdale. Mapping of the area was examined to identify an appropriate site. The following criteria were used in determining the site selection:

- connection to road network

- infrastructural barriers

- $\quad$ surrounding built form

- potential for land capture/park space development

As a result of the above criteria, the section between Dowling Avenue and Tyndall Avenue was selected for model construction (see fig. 24). 
After selection of the area for site modeling was determined, select case precedents were applied to the site at scale. The case precedents mentioned above describe internationally recognized and award winning projects. These projects solved difficult and challenging infrastructural challenges. Models of the three case studies detailed above were applied to a site specific model of the Western Toronto Waterfront. The goal of this method was to examine what unique elements of these successful projects work within the context and project components that do not work. The three case studies were selected as they are all internationally recognized projects, each offering different methods for intervening with infrastructure barriers.

Goal/process for evaluation: The goal for this project was to understand how the project integrates in with the local and surrounding urban fabric and understand the scale of the project. A model of Parkdale was constructed, rough topography lines were constructed, road and local 
infrastructure was added, and major natural features were included. Each case study was constructed to scale in paper form. The project model was placed on the Parkdale model and was examined. This method provided insight into the design elements of each project that worked well with the site. This method initiated the design process and informed the final design. The results of this method are presented in the final design (see figure 38).

3.4 Method 4: Site Visit - Identifying Connectivity in Olympic Sculpture Park

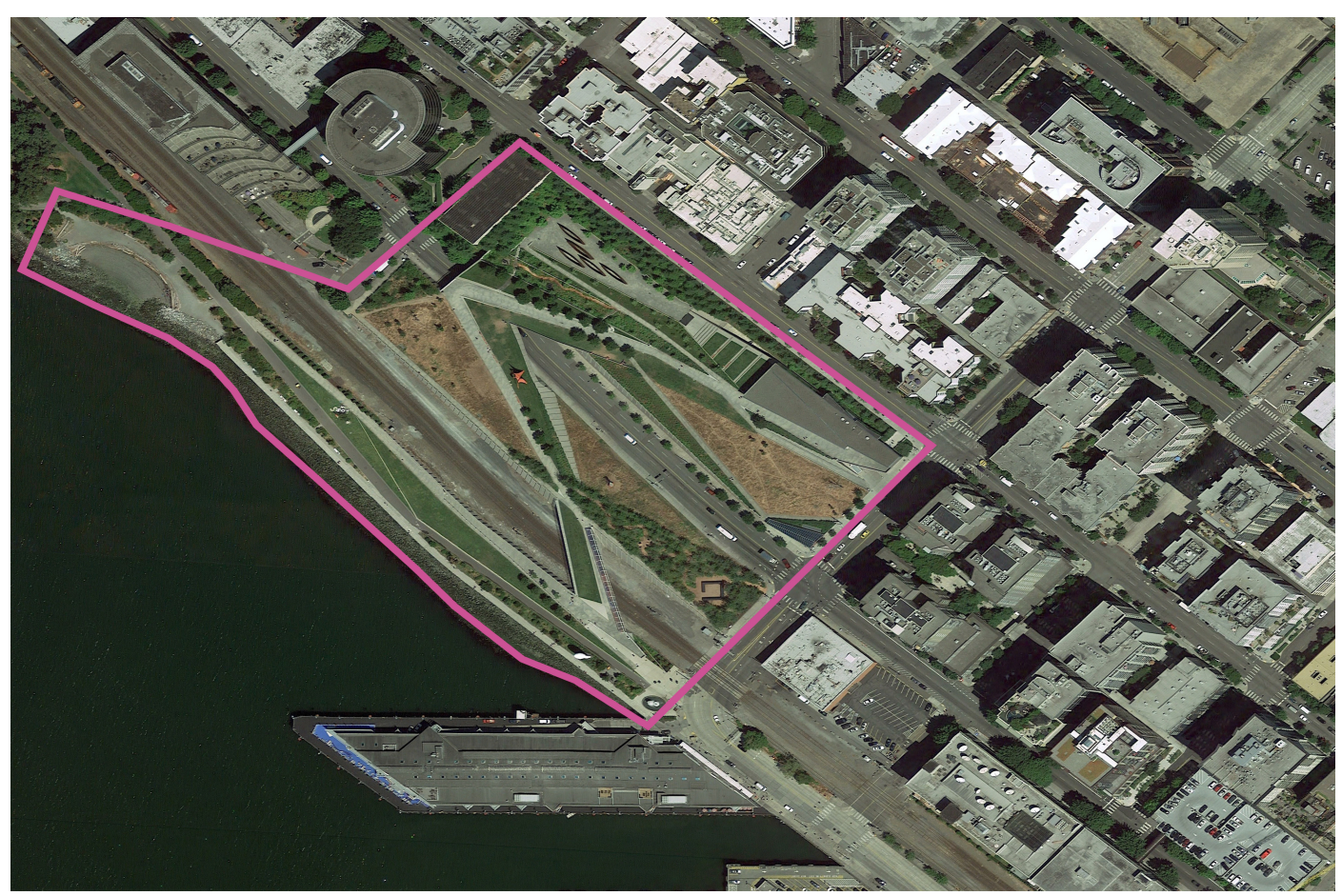

A site visit was conducted at Olympic Sculpture Park in Seattle Washington. The goal of the site visit was to examine how the project and components of the project contributed or detracted from the overall connectivity of the site. This method was used to identify the successful elements of waterfront connections and informed the design process and the final proposed design. 
A three hour site visit was conducted, photos were taken and the park was valued using the framework outlined in Jan Gehl and Birgitte Svarre's book, How to Study Public Life. Field notes and photographs were taken. Given the size of the site and the scope of this project, a limited approach of this framework was applied. Due to the size of the site and the duration of the site visit, mapping was not within the scope of the evaluation. Photographic and field notes were relied on to evaluate the connectivity of the site.

The site visit was conducted on December 22, 2014. The site was observed between the hours of 12:30pm and 2:30pm. One hundred forty three people were observed entering and using the park during the first hour, and 159 people the second hour. The weather was 10 degrees Celsius, skies were overcast with light precipitation. It should be noted that the weather conditions and time of year did not yield to favourable park conditions, however the park still attracted a large number of users during this time period. The following characteristics were observed and documented:

1. Number of Users: Counts of site users were conducted over a two hour period. Counts began and ended on the hour. Given the slope of the site, people entering and/or crossing the main structure were able to be viewed from most vantage points in the park. People who entered the main section of the site were included in this count. It is believed that this count is an accurate representation of site users.

2. Site Users: The characteristics of the site users were examined, including age, gender and group sizes. Documenting age, gender and group sizes was not feasible for this study and therefore general age ranges, gender groups, and group sizes and compositions were documented during this site visit with field notes and photographs.

3. Activity: The types of activities carried out by the users were documented with field notes and photographs. 
4. Length of Stay: The duration of the stay of the users in the park was also examined. Field notes were taken on how long people stayed and the pace of their walk.

The results of this method informed the final design. Results from method four are presented in the following section.

\subsection{Findings}

This section presents the results discussed from methods outlined in the previous chapter. 
4.1 Results from Method 1: Boundary of Parkdale

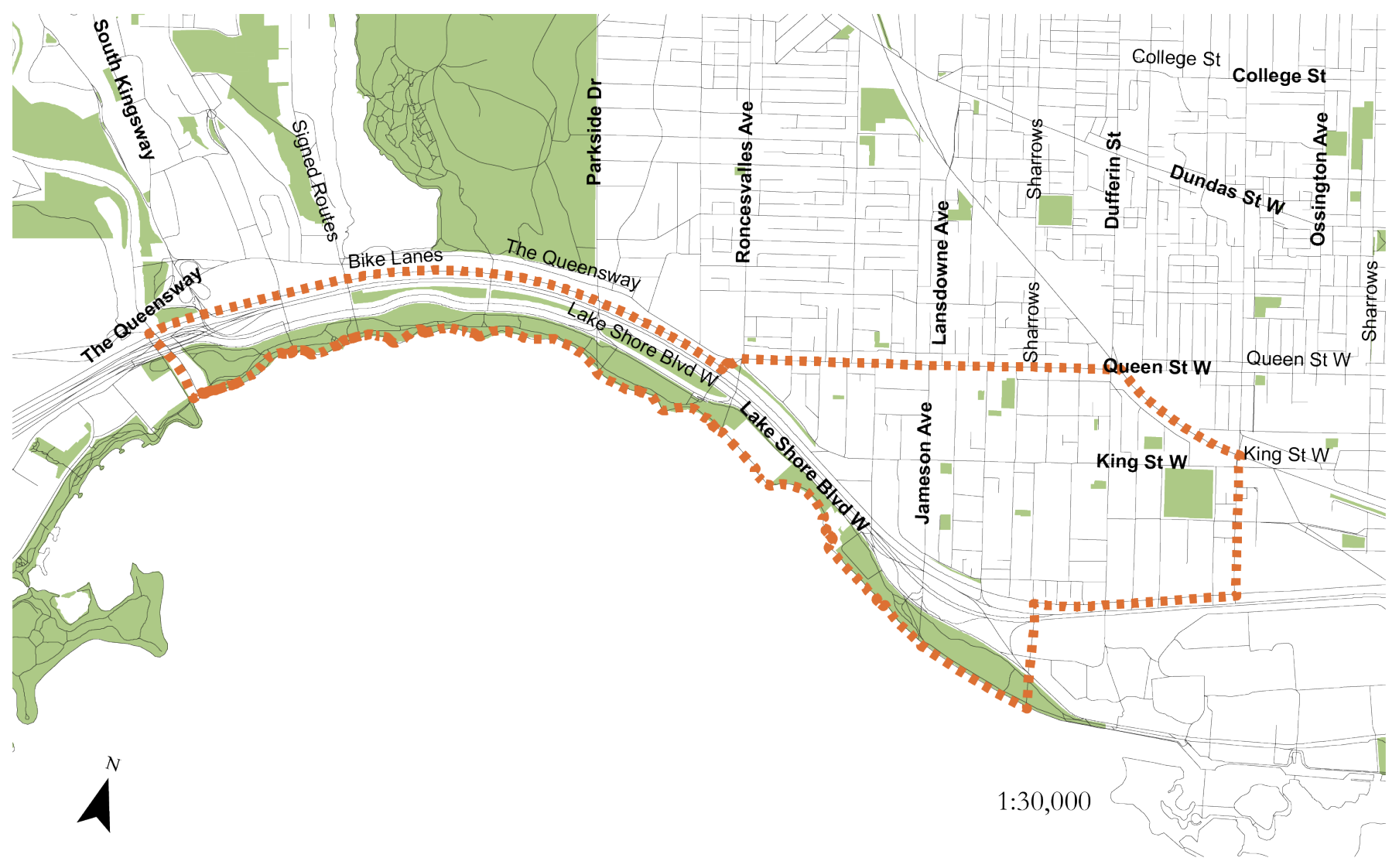

Figure 25 City of Toronto Neighbourhood Boundary

The City of Toronto neighbourhood boundaries for South Parkdale are defined in figure 26 above. The northern, eastern and western borders for South Parkdale represent appropriate neighbourhood boundaries. Roncesvalles is an appropriate western border as the street car tracks represent a significant pedestrian barrier. The change in built form north of Queen Street marks a change in the built form that is more consistent with the adjacent Roncesvalles neighbourhood. In the east, Atlantic Avenue marks a clear entrance to Liberty Village, which is also indicated by different land-use pattern (employment), and built form patterns.

The City of Toronto's definition of the South Parkdale neighbourhood includes waterfront parkland separated by a rail line, a major grade separation, and ten lanes of high speed traffic, with 
poor north/south pedestrian connections in this area. The layered infrastructure and lack of pedestrian connections act as a psychological barrier. The Western Waterfront is seen as a remote destination by residents (City of Toronto, 2009), not a part of the South Parkdale neighbourhood.

During site visits, the following site conditions were documented:

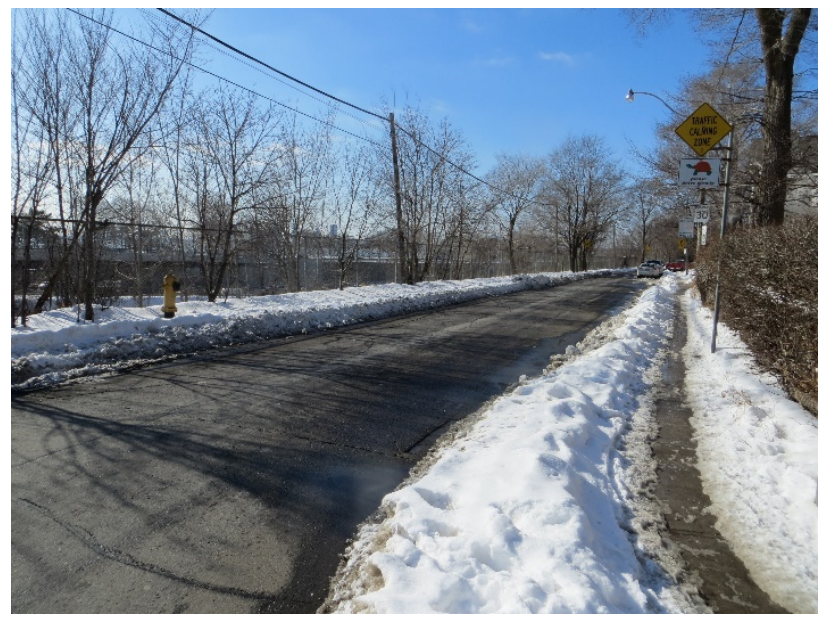

Figure 26 Rail Line (looking south at Jameson Ave. and Springhurst Ave.)

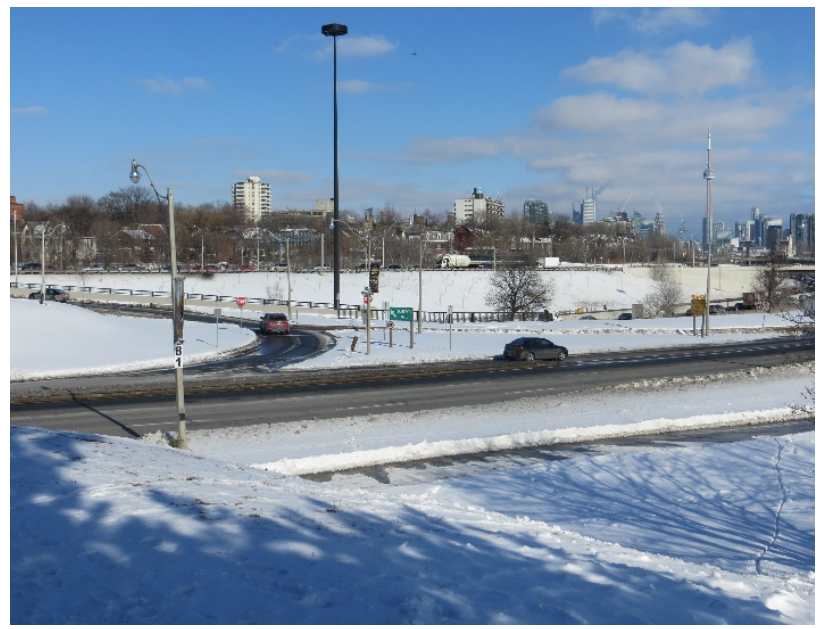

Figure 28 Looking north to Parkdale from Marilyn

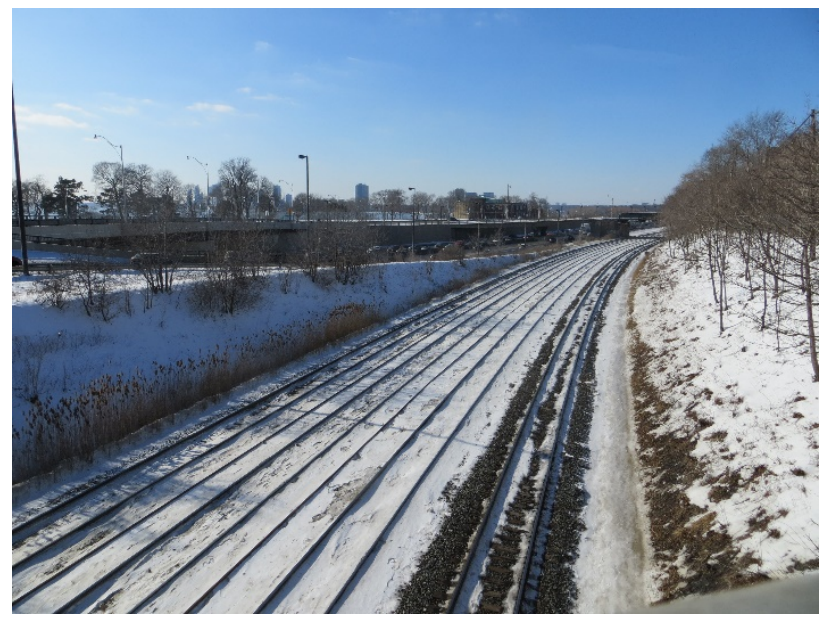

Figure 27 Rail Line (looking west at Jameson Ave.)

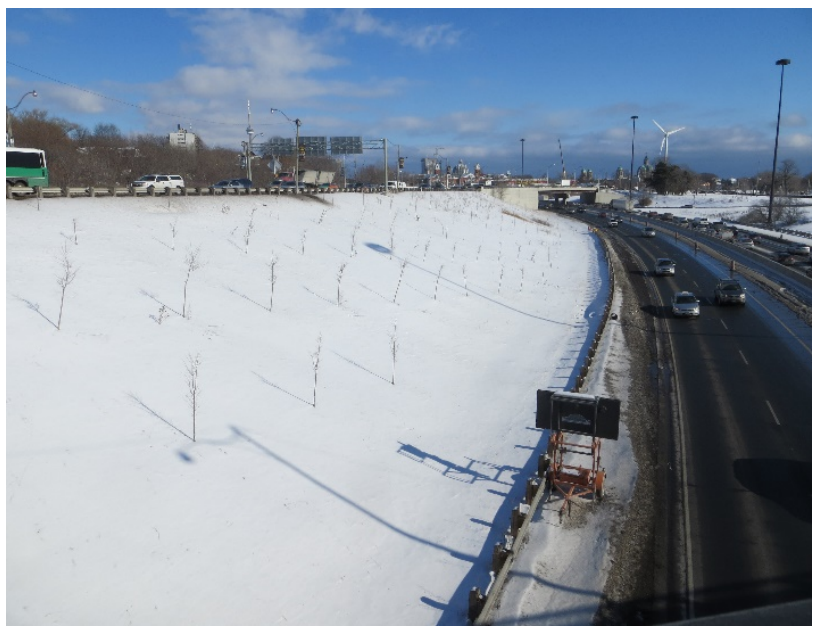

Figure 29 Gardiner Expressway (looking east from Gardiner Expressway) 


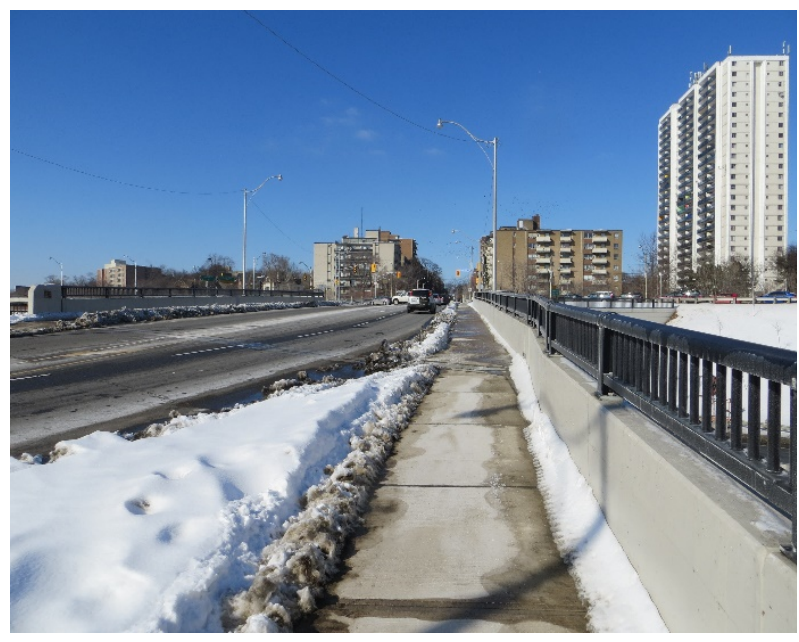

Figure 30 Looking north to Parkdale from Jameson Ave. Pedestrian Bridge

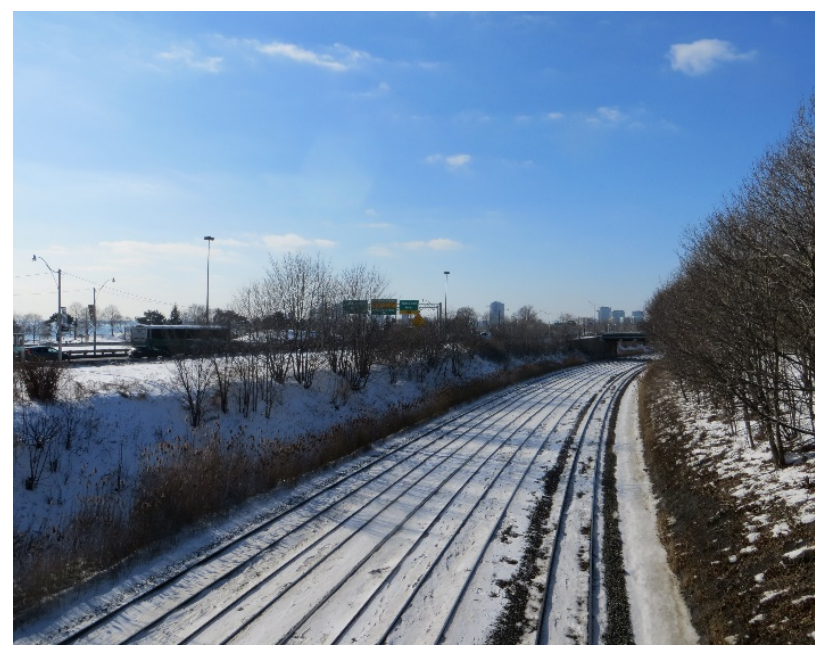

Figure 31 Looking west from Dunn Ave.

The results from method one illustrate that the physical barriers of the $\mathrm{CN}$ rail line, Lake Shore

Boulevard and the Gardiner act as strong boundaries in the South Parkdale neighbourhood and thus should be considered the southern boundary of South Parkdale. Below is a revised map (see fig. 33), illustrating the appropriate definitions of South Parkdale based on a combination of census tract maps, the City of Toronto neighbourhood boundaries, changes in built form and physical/infrastructural barriers. 


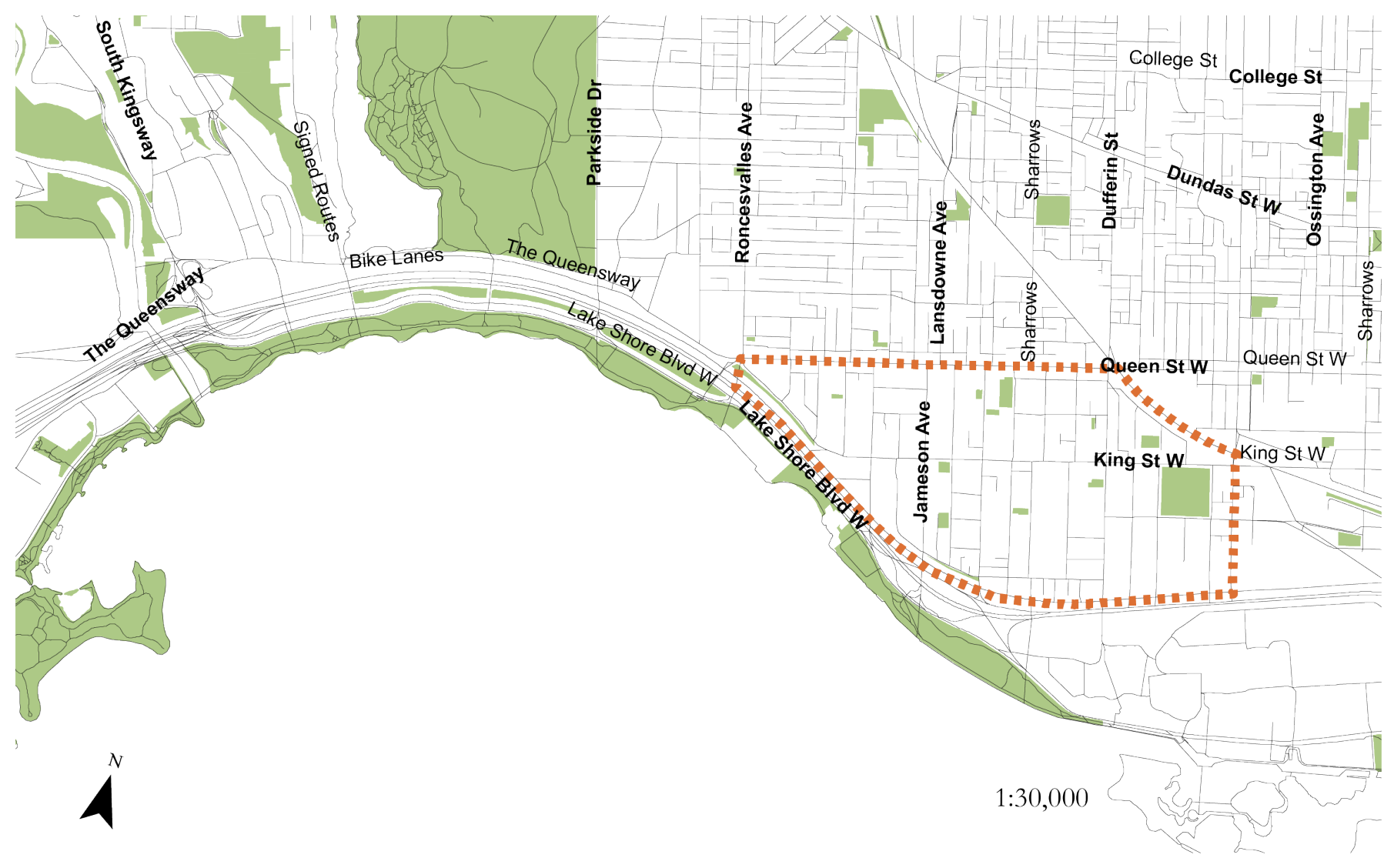

Figure 32 New Parkdale Neighbourhood Boundaries 


\subsection{Results from Method 2: Percentage of Park Space Calculation}

Parks have proven to be a valuable municipal resource and of strategic importance for achieving livability in cities. It is important that the City of Toronto capitalize on these benefits by maintaining and developing a strong park network as the city continues to grow. The City of Toronto already has a large park network and the city's parkland as a percentage of city land area is on par with other high density American cities, which as of 2012 was a mean 11.7\% (Trust for Public Land, 2012). An examination of the total number of Toronto parks and green spaces shows that mean proportion of parks and green spaces in the City of Toronto is 17\% (see Appendix A). The analysis also showed that the proportion in the City of Toronto's definition of South Parkdale neighbourhood is $20.7 \%$ (see Appendix A). While this South Parkdale number appears to be quite high, it is misleading given the neighbourhood boundaries as they are currently defined by the City

of Toronto. Excluding the area that is not pedestrian accessible from the neighbourhood definition (as described in section 4.1) reduces the proportion of green space in South Parkdale to a minuscule $2.8 \%$ of total land.

Revising the neighbourhood boundaries of Parkdale to be defined by more appropriate social and physical boundaries, as discussed in section 4.1 and presented in figure 33 , the percentage of green space as a total of neighbourhood area drastically reduced to $2.8 \%$. This number is much lower than the rest of Toronto. The results from method two illustrate a strong need for additional park space within Parkdale. This method illustrates that a connection to the existing park space along the Western Toronto Waterfront creates an opportunity to provide Parkdale residents with an abundance of park space.

4.3 Results from Method 4: Learnings from Seattle Olympic Sculpture Park 
Olympic Sculpture Park is a successful example of how an urban design project can be used to repair fractured landscapes and stitch the together the city fabric. A literature review and site visit was conducted with the goal of documenting the successes of Olympic Sculpture Park and analyzing its applicability to the neighbourhood of Parkdale.

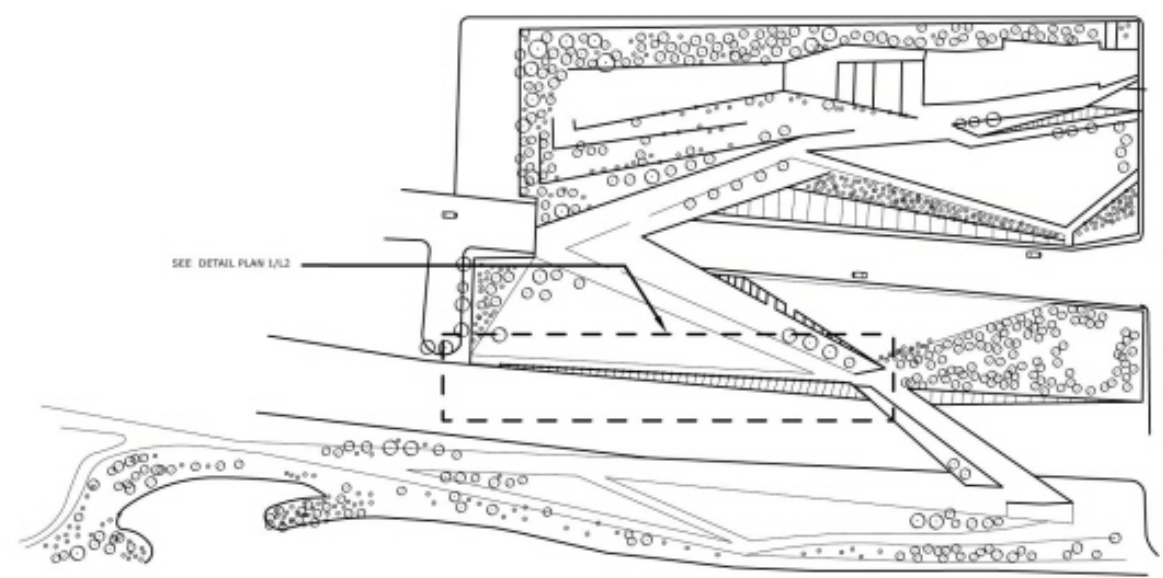

Figure 33 Map of Olympic Sculpture Park

Olympic Sculpture Park overcame similar infrastructural challenges as the selected site in Parkdale. The site occupying Olympic Sculpture Park includes four lanes of highway and a rail line, while the Parkdale site includes an active rail line, two four-lane highways and one six-lane highway. While the infrastructure in Parkdale is much more complex, the principles of Olympic Sculpture Park can be applied and elements of the design can be applied to the sections of Parkdale's site which are similar.

It is important to note that the Olympic Sculpture Park was funded through the Seattle Art Museum using private donations. As this is not a standard funding source for urban projects, a 
similar project in Toronto would have to rely on another revenue stream. As a result the proposed design outlined in section 5 recommends adding private development to help fund the development of park space and bridge development.

One of the site's designers, Michael Manfredi, noted that although Olympic Sculpture Park was originally designed to be an art attraction, the structure was unexpectedly adopted by the fitness community as local runners and walkers frequently use the space (Allen, 2011). This was observed on the site visit where the majority of the users appeared to be locals using the site for recreational activities. This shows the success of the park in its ability to host a variety of users. The site hosted a myriad of activities including (listed from most frequently to least frequent) exploring, commuting, power walking, running, dog walking, lounging and cycling. The networks of ramps and warped surfaces provided users various options for entry and exit in the park and seemed to facilitate these various activities without conflict. On the site visit a woman was observed walking and encountered another person with a dog. The dog began to bark, the dog owner decided to move from the pathway to the grass to allow the woman to continue without disturbance from the canine. The generous widths of the park and the options for alternative paths were strengths of the site design. It allowed users to adapt and gave them alternative plans when their use of the park conflicted with other site users.

There was inconsistency with the speed at which people moved through the park. Approximately half of the users explored the site, stopping to read plaques, investigating sculptures, stopping for a rest/to enjoy the view and/or lounging or resting in the provided seating. Some of the users spent their time exploring all aspects of the park, engaging in all of these activities, which the majority of explorers engaged in a combination of one or more of these activities. The other half of users moved quickly, using the site as a conduit to the waterfront. A success of the park appears 
to be the various options in site programming. The various activities and pathways allowed users to explore the site, however direct pathways were included which provided commuters with direct access to the waterfront. Both users groups were considered in the design proposal, programming was provided for users to explore, various pathways and resting places were included, including a direct pathway way for commuters to quickly access the waterfront. It is important when planning these features to ensure that space and pathways are distributed make certain that these two user groups do not conflict.

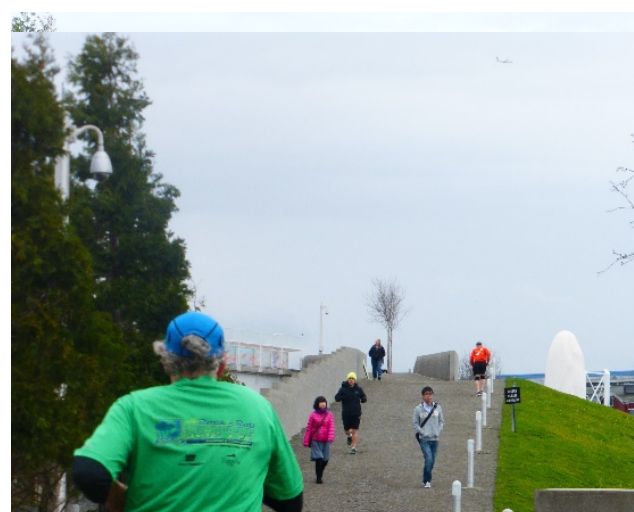

The park

provided many seating options; some options were integrated into sculptures

Figure 36 Multiple Users and some were Figure 35 Multiple Pathways movable chairs. Fixed seating options were used most often by children who climbed, explored the seating options and used the seating to sit beside someone. Movable chairs were favoured by adults, who would often reposition the chair before sitting down. The majority of all seating options were strategically placed to take advantage of the 
view of the bay. Some fixed seating did not provide a view of the waterfront, however this did not appear to deter children from playing on the furniture. The various seating options were seen as a success of the park. Moveable chairs provided adults the flexibility desired and a vantage point of the waterfront. Fixed seating afforded children opportunities to interact with the outdoor furniture and provided them with seating to sit next to their parent or sibling/friend. Various seating options were included in the design proposal to facilitate the desire for different uses.

Results from this method were used to inform the final design proposal and include: the provision of fixed a moveable seating, provision of multiple pathways to allow for exploration and to reduce conflict among users. 


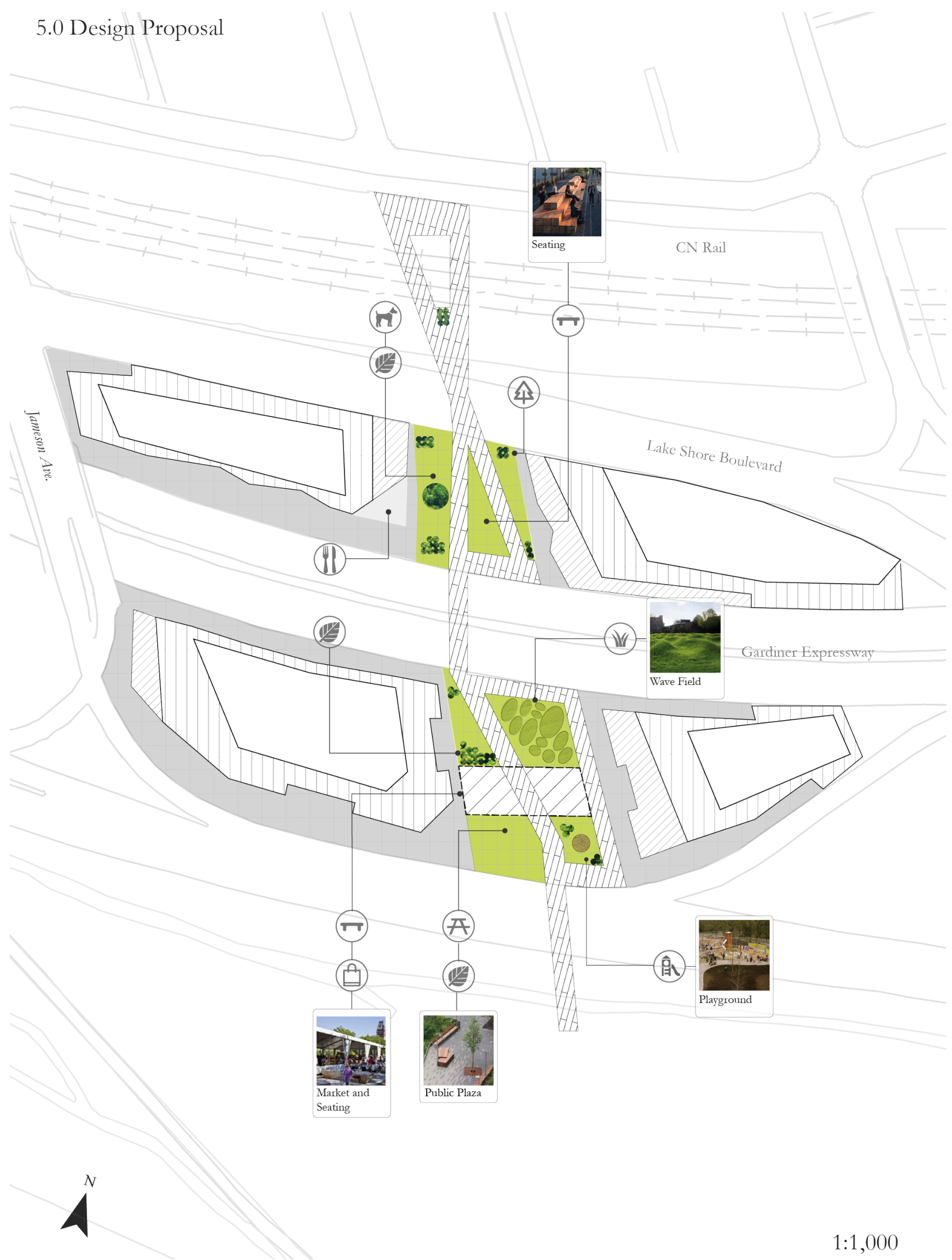

Figure 37 Proposed Design Plan View 


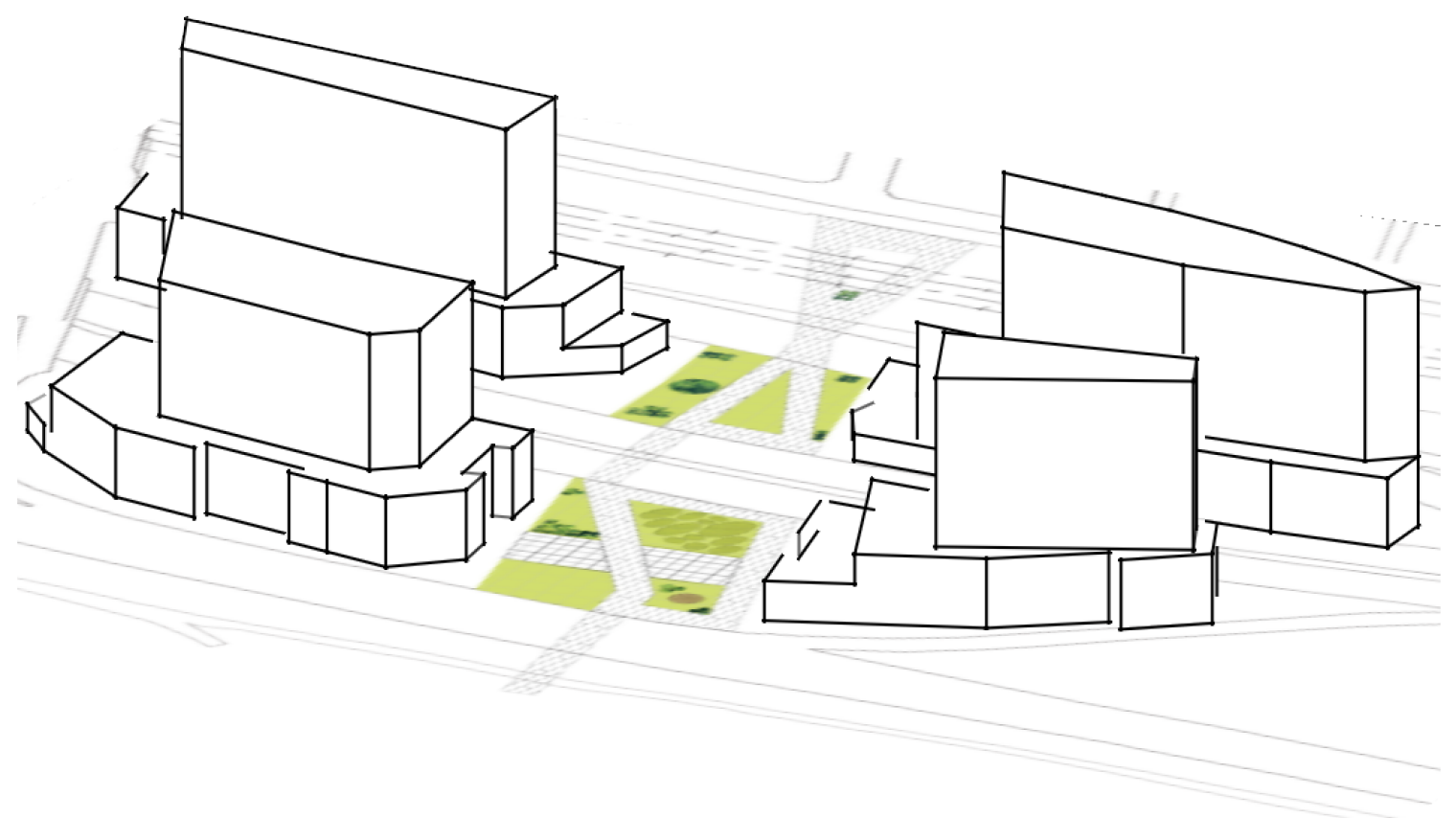

Figure 38 Proposed Design Axonometric View 


\subsection{Design Vision}

The proposed development seeks to address the planning, urban design, economic, social equity and accessibility issues mentioned earlier and incorporates the successful elements identified during the Olympic Sculpture Park site analysis. The proposed development of this site will contribute to the future vitality of the Western Toronto Waterfront and the neighbourhood of Parkdale and seeks to recreate and reimagine the successful elements that helped the Western Waterfront be a vibrant community hub during the 1920 s.

The design proposal has two elements, a mixed use development and an elevated landscape bridge that crosses over the Gardiner Expressway and Lakeshore Boulevard. The development will be mixed use with retail, commercial, cultural and residential uses. The following design principles have been established based on best practices established from the case studies mentioned above and a review of local policy. These include

1. Creation of elevated landscape bridge. This bridge will include a local park and programming to provide and create a new, accessible north/south connection to the Western Waterfront.

2. Creation of strong pedestrian plazas, storefronts and walkways. Pedestrian activity will be used to enhance activity and connection along the lakeshore.

3. Creation of public space. Public space will include a variety of programming to facilitate a variety of users.

4. Mid-rise development. This scale will be utilized to respect the scale of the existing built form and will be massed to protect and maintain important local views. 
5. Addition of Private Development. Private development will be leveraged to help fund the urban design project through section 37 funds and also provide at grade retail and commercial uses to contribute to the pedestrian realm.

6. Provision of Affordable Housing. Private development will be leveraged to help fund the provision of affordable housing

5.2 The Proposed Development

\subsubsection{Built Form}


The addition of development in the area is set to meet the demand of an increasingly competitive market in the west end. The buildings also serve as a dual purpose and seek to animate the street, encouraging pedestrian traffic in this area.

\subsubsection{Building Height}

All buildings are a maximum of 36 meters (or 11 stories) including a three-story podium. This conforms to the maximum allowable height set out in the City of Toronto Avenues \& Mid-Rise Building Study (City of Toronto, 2010). The buildings were designed to conform to the mid-rise standards as outlined in this study. The built form in South Parkdale is a mix of high-rise apartments and low-rise residential buildings (both apartments and single and semi-detaches houses), mid-rise buildings would balance these two extreme built forms and is sensitive to the surrounding context.

\subsubsection{Podium}

Included in the 36 meter building height maximum is a 10.5 meter podium. The podium is massed to create a three story street wall along Jameson Ave, the new pedestrian pathways along the Gardiner and Lake Shore Boulevard and along the new landscape feature. Building step-backs are included to maintain view corridors and also create terraces for retail and residential use. The podium stories and height were massed to conform to the City of Toronto Mid-Rise standards, which outlines a three-story, 10.5 meter tall podium with a 4.5 meter tall first floor (City of Toronto, 2010). These standards were designed based on research conducted by the City of Toronto and are seen as the ideal heights to "provide for flexibility of grade level uses and increase the marketability of retail spaces" (City of Toronto, 2010, p.44). Using this standard will allow for a variety of retail 
and commercial uses at grade. This will help animate the street and encourage pedestrian traffic to this new development and waterfront connection.

\subsubsection{Mixed Uses}

A variety of mixed uses will be provided in the development. Residential lobbies and retail/commercial uses will be located on the ground floors. Retail and commercial uses will located on the second and third floors of the podium. Residential uses will be contained in the tower and residential amenity space will be allocated to the roof of the podium.

\subsubsection{Setbacks}

The building is set back from Jameson a total of $6 \mathrm{~m}$, including the existing 2.5 meter sidewalk. This allows for a $4.5 \mathrm{~m}$ walkway and a $1.5 \mathrm{~m}$ commercial zone. Other building setbacks range from $8 \mathrm{~m}$ to $10 \mathrm{~m}$. These setbacks allow for an ample $4.5 \mathrm{~m}$ to $6 \mathrm{~m}$ walkway, a $1.5 \mathrm{~m}$ commercial zone and a $.5 \mathrm{~m}$ allowance for the appropriate fencing required to face the Gardiner Expressway and Lake Shore Boulevard.

\subsubsection{Frontage}

Building frontages range from approximately $80 \mathrm{~m}$ to $95 \mathrm{~m}$. Given the long length of the buildings, angles and cutbacks in the building were designed to add breaks and contribute to a higher quality pedestrian experience.

\subsection{The Proposed Landscape Bridge}

The elevated bridge provides a pedestrian connection from Parkdale to Marilyn Bell Park. The elevated landscape bridge will include the following features: 
- Multiple Pathways to provide the user with options for exploration and direct routes for quick access to the waterfront.

- Multiple Seating Options including built-in seating and moveable seating options to provide for flexibility of space.

- An Undulating Landscape Surface to act as an informal children's playground and to provide a natural seating area for relaxation, picnics and views of Lake Ontario.

- A Children's Play Area to attract families to the area and to contribute to the diversity of uses and users in the park.

- Integrated Public Space and Natural Elements

- Plaza for Weekend Markets

- A Pet Friendly Green Space 


\subsection{Design Discussion}

6.1 Bridging: Connecting Parks to Arrange a Neighbourhood

The results from method two illustrate a strong need for park space in South Parkdale. As

South Parkdale is identified as a Neighbourhood Improvement Area by the City of Toronto, it is of utmost important that this neighbourhood have equal access to park space as other Toronto residents. Thirty-one neighbourhoods have been identified by the City of Toronto as Neighbourhood Improvement Areas in the Strong Neighbourhood Strategy program (City of Toronto, 2014). These areas were identified based on "unnecessary, unfair and unjust differences faced by neighbourhood residents in five key areas: Economic Opportunities, Social Development, Healthy Lives, Participation in Decision-Making and Physical Surroundings" (City of Toronto, n.d.b). Increasing pedestrian accessible park space in South Parkdale is imperative to address the goals of the Strong Neighbourhood Strategy program.

City parks offer a number of social, health, psychological and economic benefits. The services that greenspace provides should be accessible to all residents of Toronto. It is necessary to connect and develop strong north/south pedestrian connections in South Parkdale to create new parkland for this community and to connect the existing Western Waterfront parkland to South Parkdale, ensuring that these resident receive equitable access to services. 


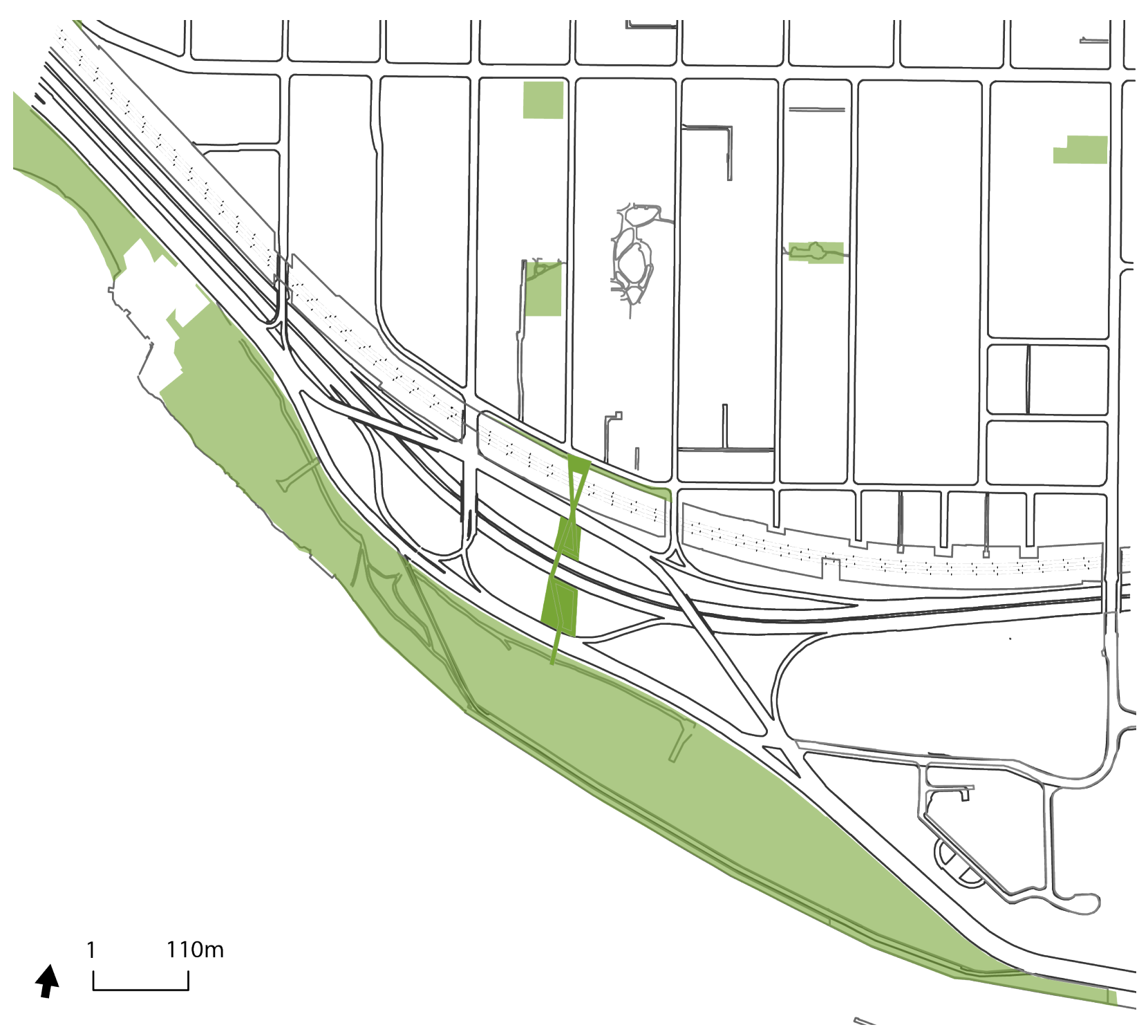

Figure 39 Parkdale Green Space Network

The proposed design offers a creative way for capturing new local parkland, while developing a connection to the existing citywide/regional parks system, ensuring equitable access to open space for residents of South Parkdale (see fig. 41). Developing a natural infrastructure system that connects the city is important and finding innovative methods for integrating green space into development is imperative for a growing city. Two key City of Toronto plans support the development of this urban design project, including the City of Toronto Parks Plan and the Central Toronto Waterfront Secondary Plan. Both plans call for the development of a green space park 
infrastructure and the development of north/south connections to help reconnect the city to the world class waterfront parks on its doorstep.

In 2013, Toronto City Council approved the 2013-2017 City of Toronto Parks Plan, which is intended to guide park development over the five year period (City of Toronto, 2013a). The plan notes several factors that influence the planning of Toronto's parks, including "a growing and changing population, the evolving expectations about the roles of parks, extensive new park development on the waterfront and limited resources for addressing the needs of a growing city" (City of Toronto, 2013a). This document is supported by the Central Toronto Waterfront Secondary Plan which promoted four key principles including, "removing barriers/making connections; building a network of spectacular waterfront parks and public spaces; promoting a clean and green environment; creating dynamic and diverse new communities" (City of Toronto, 2007, p. 10). As the selected site lies within the jurisdiction of both plans, the proposed design conforms to the document's guiding principles. Therefore, the proposed design focuses on creating connections and planning for growing and diverse communities. The primary goal of the proposed design in this project is to reconstruct the city fabric, connecting Parkdale to the waterfront parks, by removing pedestrian barriers and making connections over infrastructure. The Central Waterfront Secondary Plan states "if waterfront renewal is to be truly successful, the waterfront will have to feel like and function as part of the city fabric" (City of Toronto, 2007, p. 1). The proposed design not only seeks to repair this fragmentation and restore the historic connections, but also to create a green space gateway that enhances north/south pedestrian connections to the western waterfront's park space. Currently in the area pedestrian pathways in the South Parkdale area are limited to two crossings: 
1. Jameson Avenue - a long pedestrian crossing along an unactivated street, with disconnected pedestrian linkages. The eastern sidewalk along the Jameson Pedestrian Bridge currently does not provide access to the waterfront. The eastern portion extends from Jameson, crosses over the northern portion of Lakeshore Boulevard and the Gardiner Expressway but
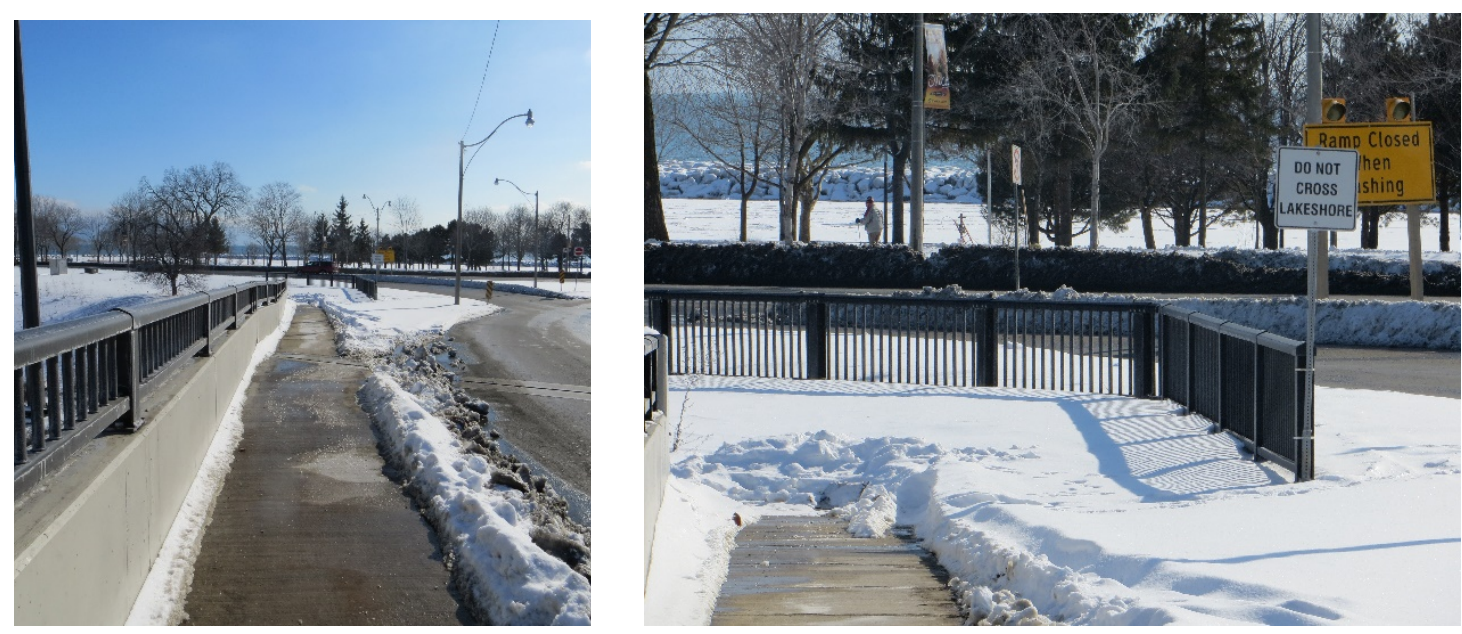

abruptly ends before the Southern portion of Lake Shore Boulevard (see fig. 42 and 43).

2. Roncesvalles Avenue - a long, pedestrian/cyclist crossing. Although designed as a multi-use crossing, the narrow width prohibits comfortable use by both user groups.

The proposed design will enhance the pedestrian walking along Jameson Street by activating the street through a pedestrian scale retail podium and will add a new connection on Close Avenue.

\subsection{Planning for Growing/Diverse Communities}

The City of Toronto is growing at a rapid pace, with the downtown core experiencing significant growth in residential development. This development pressure is increasing moving west to the Parkdale neighbourhood (City of Toronto, 2013b). In response to this expanding development pressure in the area, the City of Toronto Planning department is currently in the process of completing a planning study of the West Queen West area. City council directed the 
planning department to complete this study because of the increasing pressure for redevelopment for "the portion of Queen Street West between Bathurst Street and Roncesvalles Avenue" (City of Toronto, 2013b, p. 1). The goal of the planning study is "to address how to accommodate this development while protecting the character of the neighbourhood" (City of Toronto, 2013b, p.1). The study also seeks to address strong community concerns that increased development will result in destruction of heritage properties and the loss of local character.

The City Parks Plan identifies that with a rapidly growing population there is a need for new park space, however with this growing population there is also more competition for available land, especially along the waterfront. The West Queen West area is experiencing increased competition among developers for land, making the acquisition and provision of new park space even more challenging. The City Parks plan also identified a new direction for parkland acquisition "to prioritize parkland acquisition in underserved areas and address City priorities (City of Toronto, 2013a, p. 10). The plan acknowledges that providing parks in the current development environment “requires strong and creative parks planning” (City of Toronto, 2013a p. 20).

Several large areas of land within the South Parkdale community remain undeveloped and could be leveraged for park space and residential development. Of the area in the Western Toronto Waterfront, approximately 30 hectares is under-utilized open space. That is space "located between major pieces of transportation infrastructure, including the Queensway and CN Rail Corridor, Gardiner Expressway, Lake Shore Boulevard and the Gardiner” (City of Toronto, 2009, p. 44). These areas lie pinched between large pieces of infrastructure. The sites surrounding Jameson represent approximately 2.14 hectares of land for possible development (see fig. 44). 

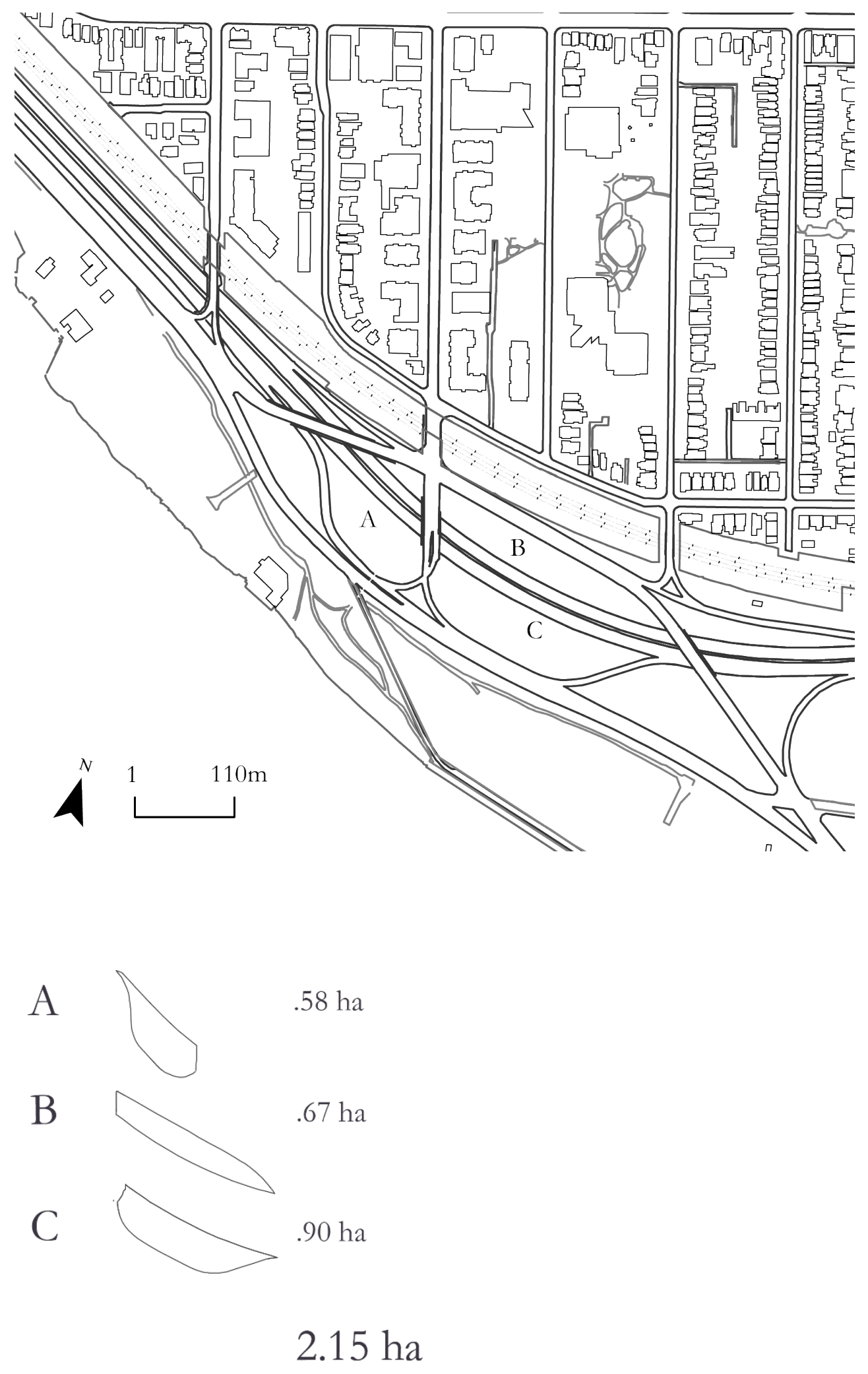
The proposed development only utilizes 1.57 hectares of land for development. Section A listed in figure 44 represents a potential area for future development.

Developing this land offers several potential economic and social benefits including:

1) Helps alleviate development pressure along Queen. There is a strong appetite for development in this area, as evidenced by the development pressures along Queen. This land occupying the selected site offers areas for development, without threatening the historical character of the neighbourhood.

2) Activates the street south of King, encouraging exploration. The area of Parkdale has largely turned its back on the lakeshore. The area south of King Street is largely residential. Adding additional buildings with grade level retail will provide an attraction to encourage community members to explore south of King Street and will help bridge a connection that entices people to explore the waterfront.

3) Leverages private development to help pay for elevated landscape bridge. Including private development in the design proposal, will not only provide the grade level retail needed to activate the street but private monies can also be leveraged through section 37 to help pay for this pedestrian connection and parkland.

4) Unlocks land where community benefits/affordable housing can be prioritized. As the City owns the land locked between the Gardiner Expressway and Lake Shore Boulevard, community benefits/affordable housing can be negotiated and prioritized in the transfer of the currently unused land to private developers.

5) Removes barriers. The Western Toronto Waterfront is disconnected from Parkdale by the rail line and fourteen lanes of high speed roadway. The construction of a bridge pathway and the development of the land that lies between Parkdale and the Waterfront will remove these barriers by allowing pedestrians to easily access the Western Waterfront. 


\subsection{Planning and Urban Design Rationale}

This section identifies the provincial and municipal policies that apply to the selected site and outlines the policies that support the proposed development.

\subsubsection{Provincial Policy}

The proposed development is supported by provincial level planning policies, namely the Provincial Policy Statement (2014) and the Growth Plan for the Greater Golden Horseshoe (2006), which outline policies that promote the efficient use of land.

Provincial Policy Statement: The Provincial Policy Statement focuses on building strong and healthy communities and includes policies that support the intensification of development in areas like Parkdale. The following policies support the proposed development:

Table 1 Provincial Policy Statement Supporting Policies

\begin{tabular}{|l|l|}
\hline Supporting Policy & Description \\
\hline Section 1.1.1 & $\begin{array}{l}\text { This section outlines the development and sustainment of healthy, livable } \\
\text { and safe communities. The section identifies increased accessibility for } \\
\text { individuals with disabilities and older persons as a key component of } \\
\text { healthy communities. The proposed development achieves this directive by } \\
\text { removing barriers to accessing the waterfront and creating a pedestrian } \\
\text { friendly and accessible pathway. }\end{array}$ \\
\hline Section 1.1.3 & $\begin{array}{l}\text { This section calls for efficient development of land, the identification of } \\
\text { intensification opportunities and the promotion of green space. The } \\
\text { proposed development achieves the goals of this policy by developing } \\
\text { previously unused city land and adding to the useable green space within } \\
\text { the city. }\end{array}$ \\
\hline Section 1.1.4 & $\begin{array}{l}\text { This section calls for the diversification of the housing stock in both } \\
\text { housing types and in the provision of affordable housing. The proposed } \\
\text { development achieves this directive by adding to the residential housing } \\
\text { stock of the neighbourhood in both areas of an affordability housing type. }\end{array}$ \\
\hline Section 1.1.5 & $\begin{array}{l}\text { This section calls for the development of parks, open space, and public } \\
\text { space that enhance the pedestrian environment and community } \\
\text { connectivity. More specifically, the section also identifies the creation of } \\
\text { public access to shorelines as an important priority. The proposed } \\
\text { development achieves this policy directive by adding to the local stock of } \\
\text { park and public space and the development of shoreline connections } \\
\text { through the creation of an elevated walkway. }\end{array}$ \\
\hline
\end{tabular}


Growth Plan for the Greater Golden Horseshoe: In addition to the Provincial Policy Statement, the Growth Plan for the Greater Golden Horseshoe is another provincial policy document which directs development on the selected site. The Growth Plan outlines its objectives:

- Revitalize downtowns to become vibrant and convenient centres

- Create complete communities that offer more options for living, working, learning, shopping and playing

- Provide housing options to meet the needs of people at any age

- Curb sprawl and protect farmland and green spaces

- $\quad$ Reduce traffic gridlock by improving access to a greater range of transportation options

To achieve these objectives, the Growth Plan identifies areas for intensification. The selected site is located in an area for intensification. The design proposal meets the objectives of the Growth Plan by utilizing vacant land that will be serviced by municipal infrastructure and help curb sprawl by increasing the housing stock in a designated intensification area.

\subsubsection{Municipal Policy}

Two municipal policy documents guide planning decisions in the area: the City of Toronto Official Plan and the Central Waterfront Secondary Plan.

Official Plan: The City of Toronto Official Plan is the regulatory document that guides decisions related to transit, land use development, and the environment in the city.

Land Use Designations: In the official plan, the area examined for design is designated as park space and a utility corridor. A Utility Corridor designation allows for the development of parks and pedestrian trails. The proposed design therefore conforms with the permitted uses in utility corridor land use designation. The land use designation of Park space does not permit the development of private uses on the site. The area designated as park space is presently landlocked by complex 
infrastructural systems, preventing the site from being accessible. This policy is likely more indicative of a land use designation that is outdated than a strategic planning direction. Therefore, the proposed development will require an OP land use amendment. However, the land use requirement amendment required by the design proposal is supported by policies in the Provincial Policy Statement, the Growth Plan for the Greater Golden Horseshoe and the City of Toronto Official Plan.

Table 2 City of Toronto Official Plan Supporting Policies

\begin{tabular}{|c|c|}
\hline Description & Supporting Policies \\
\hline $\begin{array}{l}\text { The City of Toronto Official } \\
\text { Plan policies support the } \\
\text { proposed design's directive to } \\
\text { improve the green space system } \\
\text { and develop the currently } \\
\text { under-utilized public land into } \\
\text { public parks space. }\end{array}$ & $\begin{array}{l}\text { Actions will be taken to improve, preserve and enhance the } \\
\text { Green Space System by: improving public access and } \\
\text { enjoyment of lands under public ownership (2.3.2.1.a) } \\
\text { - The Green Space System will be expanded by linking } \\
\text { additional parks and open spaces: acquiring such linkages, } \\
\text { where feasible (2.3.2.2.a). }\end{array}$ \\
\hline $\begin{array}{l}\text { The City of Toronto OP } \\
\text { recognizes the importance of } \\
\text { waterfront access and promotes } \\
\text { developments, like the proposed } \\
\text { design, which encourage access } \\
\text { to this space. The proposed } \\
\text { design will achieve the policy's } \\
\text { objectives by minimizing the } \\
\text { physical barriers caused by the } \\
\text { Gardiner and Lake Shore } \\
\text { Boulevard and will provide } \\
\text { viewing platforms to the lake. }\end{array}$ & $\begin{array}{l}\text { - Increased public enjoyment and use of lands along the } \\
\text { water's edge will be promoted by ensuring the future } \\
\text { development and actions on the park of both the public and } \\
\text { private sectors, including the Toronto Port Authority, the } \\
\text { Toronto Waterfront Revitalization Corporation and the } \\
\text { Toronto Region Conservation, will help achieve the } \\
\text { following objectives: } \\
\text { - minimize physical and visual barriers between the City } \\
\text { and Lake Ontario (Section 2.3.2.6.a) } \\
\text { - increase and improve public access to lands along the } \\
\text { water's edge and between parts of the waterfront } \\
\text { (2.3.2.6.b) } \\
\text { - improve the public realm with more parks, public } \\
\text { squares and natural settings that please the eye and lift }\end{array}$ \\
\hline
\end{tabular}




\begin{tabular}{|c|c|}
\hline & $\begin{array}{l}\text { the spirit and support a sense of belonging to the } \\
\text { community (2.3.2.6.d) } \\
\text { - The natural features of the City, such as the Lake Ontario } \\
\text { shoreline, the Lake Iroquois escarpment, woodlots, ravines } \\
\text { and valley lands, will be connected to the surrounding city } \\
\text { by improving physical and visual access from adjacent } \\
\text { public spaces and by designing these into a comprehensive } \\
\text { open space network (3.1.1.4) }\end{array}$ \\
\hline $\begin{array}{l}\text { The Official Plan emphasizes } \\
\text { the importance of the public } \\
\text { realm. The proposed design is } \\
\text { centered around the creation of } \\
\text { a lively streetscape animated } \\
\text { with landscape and activities. }\end{array}$ & $\begin{array}{l}\text { City streets are a significant public open space that serve } \\
\text { pedestrians and vehicles, provide space for public utilities } \\
\text { and services, trees and landscaping, building access, } \\
\text { amenities such as view corridors, sky view and sunlight, and } \\
\text { are public gathering places. Streets will be designed to } \\
\text { perform their diverse roles, balancing the spatial needs of } \\
\text { existing and future users within the right-of-way. This } \\
\text { includes pedestrians, people with mobility aids, transit, } \\
\text { bicycles, automobiles, utilities and landscaping (3.1.1.5) } \\
\text { Sidewalks and boulevards will be designed to provide safe, } \\
\text { attractive, interesting and comfortable spaces for pedestrians } \\
\text { (3.1.1.6) }\end{array}$ \\
\hline $\begin{array}{l}\text { Maintaining and creating } \\
\text { connections across the city is } \\
\text { recognized by the Toronto } \\
\text { Official Plan as an important } \\
\text { planning objective. The goal of } \\
\text { the proposed design is to } \\
\text { recreate the lost historic } \\
\text { waterfront connection from } \\
\text { Parkdale to the Western } \\
\text { Toronto Waterfront. }\end{array}$ & $\begin{array}{l}\text { - Toronto's concession road grid is a major organizing } \\
\text { element to be maintained, improved and recognized in } \\
\text { public design initiatives. To improve mobility and } \\
\text { recreational opportunities where these streets are } \\
\text { interrupted by topographical features of utility corridors, } \\
\text { pedestrian and bicycle routes should be established across } \\
\text { these features (3.1.1.7). } \\
\text { - New streets will be designed to: } \\
\text { - provide connections with adjacent neighbourhoods, } \\
\text { and promote a connected grid of streets that offers }\end{array}$ \\
\hline
\end{tabular}




\begin{tabular}{|c|c|}
\hline & $\begin{array}{l}\text { travel options and extends sight lines (3.1.1.14.a) } \\
\text { - provide access and addresses for new development } \\
\text { (3.1.1.14.c) } \\
\text { - improve the visibility, access and prominence of unique } \\
\text { natural and human-made features; and (3.1.1.14.f) }\end{array}$ \\
\hline $\begin{array}{l}\text { The creation of high quality } \\
\text { urban parks is recognized by the } \\
\text { Toronto Official Plan as an } \\
\text { important planning objective. } \\
\text { The goal of the proposed design } \\
\text { is to capture vacant land, } \\
\text { previously thought of unusable, } \\
\text { to develop into park space for } \\
\text { the expanding community. }\end{array}$ & $\begin{array}{l}\text { - Toronto's system of parks and open spaces will continue to } \\
\text { be a necessary element of city-building as the City grows and } \\
\text { changes. Maintaining, enhancing and expanding the system } \\
\text { requires the following actions: } \\
\text { - adding new parks and amenities, particularly in growth } \\
\text { areas and maintaining, improving and expanding } \\
\text { existing parks (3.2.3.1.a) } \\
\text { - designing high quality parks and their amenities to } \\
\text { promote user comfort, safety, accessibility and year- } \\
\text { round use and to enhance the experience of "place", } \\
\text { providing experiential and educational opportunities to } \\
\text { interact with the natural world (3.2.3.1.b); } \\
\text { - protecting access to existing publicly accessible open } \\
\text { spaces, as well as expanding the system of open spaces } \\
\text { and developing open spaces linkages (3.2.3.1.c); and } \\
\text { - promoting and using private open space and recreation } \\
\text { facilities, including areas suitable for community for } \\
\text { allotment gardening, to supplement the City's parks, } \\
\text { facilities and amenities (3.2.3.1.d). }\end{array}$ \\
\hline
\end{tabular}


Central Waterfront Secondary Plan: As mentioned above, the selected site also lies within the Central Waterfront Secondary Plan jurisdiction. The core principles and policies outlined in the secondary plan were used to inform the design proposal.

Table 3 Central Waterfront Secondary Plan Design Principles \& Supporting Policies

\begin{tabular}{|c|c|}
\hline Design Principle & Supporting Policies \\
\hline $\begin{array}{l}\text { Elevated landscape bridge will } \\
\text { include public space, local parks } \\
\text { and activity to provide and } \\
\text { create a new north/south } \\
\text { connection to the Western } \\
\text { Waterfront. }\end{array}$ & $\begin{array}{l}\text { Physical connections between the Central Waterfront, the } \\
\text { downtown core and adjacent neighbourhoods will be } \\
\text { enhanced through high-quality urban design and } \\
\text { landscaping on the north/south connector streets (P7). } \\
\text { - Local parks will enrich new waterfront communities. Parks } \\
\text { planning will take into account such factors as park size, } \\
\text { land availability, neighbourhood accessibility, safety and } \\
\text { quality of experience in park spaces (P34). }\end{array}$ \\
\hline $\begin{array}{l}\text { Creation of strong pedestrian } \\
\text { plazas, storefronts and walkways } \\
\text { to enhance activity and } \\
\text { connection along the Lakeshore. }\end{array}$ & $\begin{array}{l}\text { The public realm will be defined by a coherent framework } \\
\text { of streets, parks, plazas, buildings, viewing areas, walkways, } \\
\text { boardwalks, promenades, piers, bridges and other public } \\
\text { infrastructure and open space elements. Its design will } \\
\text { reflect its exceptional waterfront setting and integrate and } \\
\text { interpret the rich natural and cultural heritage of Toronto's } \\
\text { waterfront, its industrial dockwall legacy as well as the } \\
\text { historic Lake Ontario Shoreline, Taddle Creek and Garrison } \\
\text { Creek alignments (P11). } \\
\text { - Parks and plazas strategically located along the water's edge } \\
\text { will become centres of public activity - in effect, windows } \\
\text { on the lake (P12). } \\
\text { - Pedestrian and cycling routes will be safe, attractive, } \\
\text { comfortable and generously landscaped (P21). }\end{array}$ \\
\hline $\begin{array}{l}\text { Creation of public space with a } \\
\text { variety of programming to }\end{array}$ & - Parks in the central waterfront will be diverse, well \\
\hline
\end{tabular}




\begin{tabular}{|c|c|}
\hline facilitate a variety of users. & $\begin{array}{l}\text { maintained, animated and safe, accommodating a full } \\
\text { range of recreational experiences from areas for active } \\
\text { plan, enjoyment of sports and entertainment to areas for } \\
\text { quiet solitude and relaxation. These experiences will be } \\
\text { provided in a comfortable setting during all seasons of the } \\
\text { year (P15). } \\
\text { - A wide variety of year-round experiences for visitors will } \\
\text { be offered. Emphasis will be placed on developing new } \\
\text { facilities that are enduring, creative and unique to Toronto } \\
\text { and its waterfront. Winter conditions will be an important } \\
\text { consideration in developing the Central Waterfront's } \\
\text { tourism infrastructure (P47). }\end{array}$ \\
\hline $\begin{array}{l}\text { Mid-rise development will be } \\
\text { utilized to respect the scale of } \\
\text { the existing built form and will } \\
\text { be massed to protect and } \\
\text { maintain important local views. }\end{array}$ & $\begin{array}{l}\text { - Development of the Central Waterfront will maintain } \\
\text { Toronto's successful tradition of city building at a } \\
\text { compact scale combining the best of urban living, } \\
\text { amenities and built form. The treatment of the } \\
\text { development sites abutting the water's edge, public } \\
\text { promenade along the traditional urban dockwall will } \\
\text { require particular sensitivity to create a front of publicly } \\
\text { accessible and marvellous buildings of appropriate low to } \\
\text { moderate scale to complement the character of the } \\
\text { neighbourhoods and in keeping with good planning } \\
\text { principles (P30). } \\
\text { New development will be located, organized and massed } \\
\text { to protect view corridors, frame and support the adjacent } \\
\text { public realm and discourage privatization of public spaces. } \\
\text { Built form will result in comfortable micro-climes on } \\
\text { streets, plazas and other parts of the public realm (P32) }\end{array}$ \\
\hline $\begin{array}{l}\text { Private development will be } \\
\text { leveraged to help fund the urban } \\
\text { design project and also provide } \\
\text { at grade retail and commercial } \\
\text { uses to contribute to the }\end{array}$ & $\begin{array}{l}\text { - Excellence in the design of public and private buildings, } \\
\text { infrastructure (streets, bridges, promenades, etc.) parks } \\
\text { and public spaces will be promoted to achieve quality, }\end{array}$ \\
\hline
\end{tabular}




\begin{tabular}{|c|c|}
\hline pedestrian realm. & $\begin{array}{l}\text { beauty and worldwide recognition (P31) } \\
\text { - Innovative approaches for providing the necessary } \\
\text { community infrastructure will be explored, including } \\
\text { shared use of schools, community services and faculties } \\
\text { and local parks as well as integrating community facilities } \\
\text { into private developments (P36) }\end{array}$ \\
\hline $\begin{array}{l}\text { Private development will be } \\
\text { leveraged to help fund the } \\
\text { provision of affordable housing. }\end{array}$ & $\begin{array}{l}\text { - The overall goal for the Central Waterfront is that } \\
\text { affordable rental housing and low-end-of market housing } \\
\text { comprise } 25 \text { per cent of all housing units (P39). }\end{array}$ \\
\hline
\end{tabular}




\subsection{Study Next Steps}

The design proposal includes preliminary analysis of the site and will require future research and areas of study. The next steps for areas of study include:

Community Services and Facilities Report - Within the development there is a designated area for a city owned community services facility. The city should conduct an inventory of local community services and facilities to identify the existing resources in the area and prioritize missing services that would be best utilized in this space.

Wind and Shadow Study: A preliminary sun and shadow study was conducted to direct the tower placement. A pedestrian level wind assessment should also be condition to aid in determining how the development will impact the microclimate and pedestrian comfort conditions.

Geotechnical and Structural Analysis Report: A geotechnical and structural analysis will need to be conducted to complete a thorough feasibility analysis of constructing the proposed buildings on the site's soil conditions and topography.

Municipal Servicing and Storm Water Management Report: A report outlining how municipal servicing, including water, sanitary and storm water management, will be provided for the site should be conducted.

Traffic and Parking Analysis and Site Circulation: A report should be conducted to determine the projected traffic volumes generated by the site and the impact on the surrounding community. The feasibility of the proposed points of entrance and egress should also be future analyzed. Parking analysis of the site should also be conducted. 


\subsection{Conclusion}

Urban planners play a key role in the creation of the city. Often called 'city builders', urban planners create the planning and design policy that guides, directs and informs urban projects. These policies not only guide the planning profession but also impact the work of architects, urban designers and landscape architects as they attempt to design projects that impact and change the city structure.

The case studies of the Barcelona Waterfront, Boston's Big Dig and Seattle's Olympic Sculpture Park illustrate innovative urban landscape projects that occur outside the traditional design approach. It is important that planners understand the work of their allied professionals to aid in the creation of successful urban projects that are the result of emerging urban theories. Landscape urbanism, although in its infancy as a theory of urban planning, offers promising solutions for the transformation of previously unusable space into the public realm. It offers a new lens for evaluating the forgotten spaces in the urban environment.

The practice of urban design, and by extension landscape urbanism, is primarily directed by urban planning policy, yet remains in the domain of architecture. This project is an attempt to integrate the professional knowledge of urban designers, landscape architects and architects into the planning profession. It seeks to build a design skill set that planners often lack. By participating in the design discussion, planners are better equipped to critically evaluate emerging design fields, assess their appropriateness and develop planning and design policy that supports successful projects. As planners set the policies that direct urban design, they should be at the forefront of design, not responding to it. Creating interdepartmental project teams within municipalities and updating existing policy to allow for design flexibility offers a new way forward for urban planning. 
Parks and Recreation, City Planning, Transportation and Architecture/Heritage often remain disconnected in municipal practice. The interdisciplinary approach of landscape urbanism pairs the innovative work of architects and landscape architects with the long term visioning of urban planners and designers to solve the complex problems of the city. This work attempts to demonstrate how to reclaim forgotten territories. As this project illustrates, there are areas in the city that may remain inappropriately undeveloped. Planning policy and land use designations should be updated to allow for the flexibility and adaptability in developing spaces between infrastructural systems. With increasing land values and decreasing land availability these areas are becoming more attractive for development. Planning policies should reviewed and evaluated for opportunities to be more nimble and be updated to accommodate this changing planning environment.

This design project seeks to address one missing connection along the Western Toronto Waterfront. Several projects will need to be undertaken to address the connection of the lakeshore as a whole. This project will not erase the past 50 years of planning that prioritized planning for cars over planning for public space. Future research should be conducted to explore key missing connections in the Western Toronto Waterfront and other areas of the City. 
Appendix A: Park Space Calculation Results

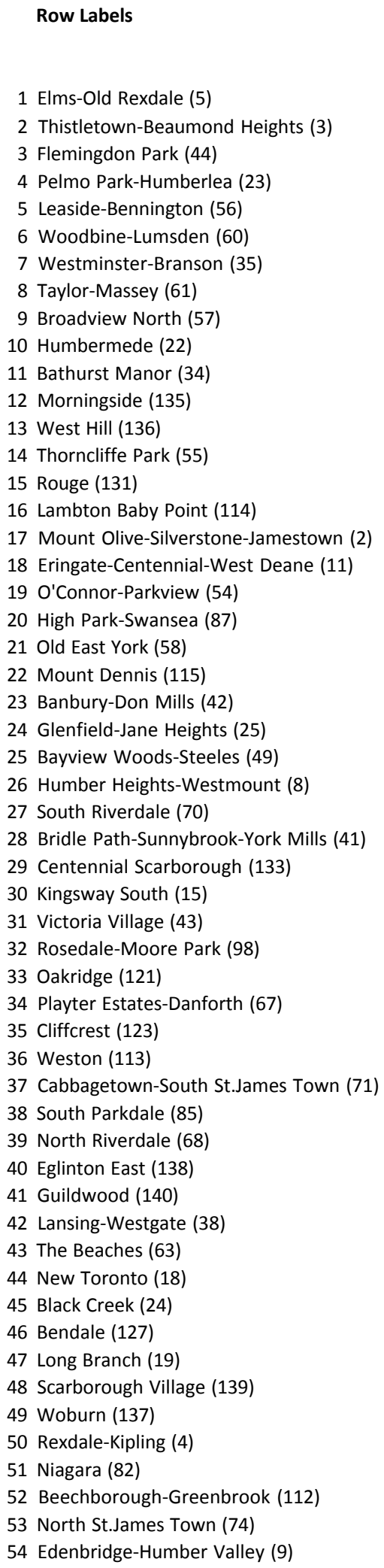

Sum of Area_Parkspace Area_Neigh_Hectares

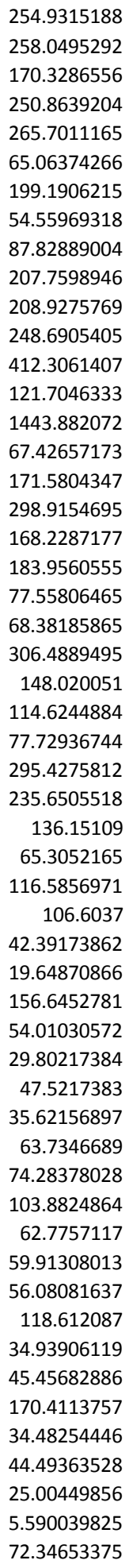

Proportion of park space (park space/total space)

293.2066477

0.86946022

0.7724832

0.68855414

0.58648968

0.55518987

0.54380693

0.54295099

0.51320910

0.50294027

0.46973441

0.43878167

0.43318942

0.42830310

0.38919368

0.38463242

0.37830672

0.36986605

0.34564209

0.34490347

0.34325291

0.3299928

0.32105480

0.30515954

0.28735143

0.28027067

0.27726158

0.26938686

0.2665642

0.24895597

0.24747359

0.24512649

0.22828165

0.22562292

0.22133002

0.21778838

0.21045946

0.21014176

0.20774279

0.19940244

0.19770571

0.19523460

0.19426452

0.17455321

0.17205301

0.16232777

0.15904892

0.15443082

0.14423981

0.13814250

0.13757894

0.13724297

0.13633564

0.13175671

0.13122625 
55 Humber Summit (21)

56 Parkwoods-Donalda (45)

57 Trinity-Bellwoods (81)

58 Brookhaven-Amesbury (30)

59 Rustic (28)

60 Humewood-Cedarvale (106)

61 Birchcliffe-Cliffside (122)
104.4257349

96.33005497

21.42317414

43.03792183

25.12413881

22.39293472

71.58657998
796.9207309

746.5806025

172.9996817

350.8196802

209.691891

187.160014

600.9945084
7

0.1310365

0.12902833

0.12383360

0.12267818

0.11981454

0.11964593

0.11911353 
62 Rockcliffe-Smythe (111)

63 Mimico (includes Humber Bay Shores) (17)

64 St.Andrew-Windfields (40)

65 Forest Hill North (102)

66 Waterfront Communities-The Island (77)

67 Steeles (116)

68 Bayview Village (52)

69 Stonegate-Queensway (16)

70 York University Heights (27)

71 Casa Loma (96)

72 lonview (125)

73 Keelesdale-Eglinton West (110)

74 Yonge-Eglinton (100)

75 Henry Farm (53)

76 Church-Yonge Corridor (75)

77 L'Amoreaux (117)

78 Kingsview Village-The Westway (6)

79 Etobicoke West Mall (13)

80 Downsview-Roding-CFB (26)

81 Bay Street Corridor (76)

82 Clairlea-Birchmount (120)

83 West Humber-Clairville (1)

84 Malvern (132)

85 Markland Wood (12)

86 Hillcrest Village (48)

87 Moss Park (73)

88 Woodbine Corridor (64)

89 Corso Italia-Davenport (92)

90 Maple Leaf (29)

91 Willowridge-Martingrove-Richview (7)

92 Mount Pleasant East (99)

93 Alderwood (20)

94 Tam O'Shanter-Sullivan (118)

95 Dovercourt-Wallace Emerson-Junction (93

96 Greenwood-Coxwell (65)

97 Englemount-Lawrence (32)

98 Lawrence Park South (103)

99 Yorkdale-Glen Park (31)

100 Junction Area (90)

101 Don Valley Village (47)

102 Dufferin Grove (83)

103 Milliken (130)

104 Pleasant View (46)

105 Willowdale West (37)

106 Forest Hill South (101)

107 University (79)

108 East End-Danforth (62)

109 Wexford/Maryvale (119)

110 Highland Creek (134)

111 Princess-Rosethorn (10)

112 Briar Hill-Belgravia (108)

113 Newtonbrook East (50)

114 Kensington-Chinatown (78)

115 Caledonia-Fairbank (109)

116 Willowdale East (51)

117 Annex (95)

118 Wychwood (94)

119 Mount Pleasant West (104)

120 Islington-City Centre West (14)

121 High Park North (88)

122 Newtonbrook West (36)

123 Agincourt North (129)

124 Yonge-St.Clair (97)

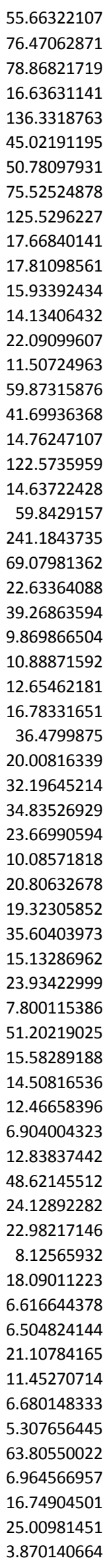

507.2009352

0.10974589

0.10830117

0.10802056

0.10600112

0.1015969

0.09868630

0.09840852

0.09502426

0.09473855

0.0918877

0.09118918

0.09098878

0.08562093

0.08517204

0.08431272

0.0836682

0.08233194

0.08214273

0.08173667

0.0808846

0.0808833

0.07998320

0.07790155

0.07660314

0.07276545

0.06983548

0.06822777

0.06712972

0.06641266

0.06609857

0.06476176

0.06465450

0.06423326

0.06351466

0.06019677

0.05980681

0.05958224

0.05894952

0.05748539

0.05680799

0.05618533

0.05401388

0.05250309

0.05030438

0.05025934

0.04912073

0.04864163

0.0473625

0.04597112

0.04442880

0.04438410

0.04427830

0.04310719

0.04210819

0.0416975

0.04103601

0.03970568

0.03950588

0.03927844

0.03699198

0.03566110

0.03443390

0.03331929

7 


125 Kennedy Park (124)
126 Danforth East York (59)
127 Dorset Park (126)
128 Roncesvalles (86)
129 Agincourt South-Malvern West (128)
130 Bedford Park-Nortown (39)
131 Palmerston-Little Italy (80)
132 Weston-Pellam Park (91)
133 Clanton Park (33)
134 Regent Park (72)
135 Oakwood Village (107)
136 Little Portugal (84)
137 Lawrence Park North (105)
138 Blake-Jones (69)
139 Runnymede-Bloor West Village (89)
140 Danforth (66)

$\begin{array}{rr}11.90072678 & 358.1360744 \\ 7.029842669 & 218.8999755 \\ 19.22172224 & 601.3073175 \\ 4.763803066 & 150.4851663 \\ 23.97495005 & 787.4514515 \\ 16.57382026 & 551.9507524 \\ 3.884142004 & 143.5569878 \\ 3.621929823 & 146.0933374 \\ 10.11119712 & 414.3511854 \\ 1.481429458 & 65.04026446 \\ 4.907797246 & 221.9882474 \\ 2.492308123 & 121.660656 \\ 4.2787863 & 229.0409409 \\ 1.703893446 & 94.13717192 \\ 1.245377693 & 159.4349899 \\ 0.183712096 & 111.9879564\end{array}$

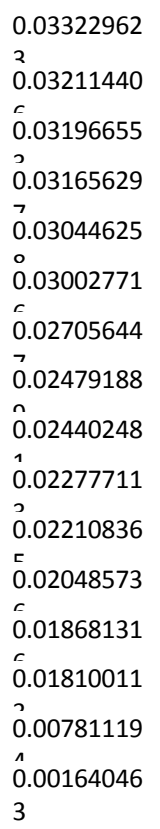




\section{References}

Allen, S., \& McQuade, M. (Eds.). (2011). Landform building: architecture's new terrain. Lars Müller Publishers.

Allen, S. (2011). From the biological to the ecological. In Allen, S., \& McQuade, M. (Eds.), Landform building: architecture's new terrain. (pp. 20-37). Lars Müller Publishers.

Allen, S. (2011). Gwanggyo Pier Lakeside Park. In Allen, S., \& McQuade, M. (Eds.), Landform building: architecture's new terrain. (pp. 222-230). Lars Müller Publishers.

Berjis, P., \& Panesar, D. K. (2011). Another perspective on success and failure case studies in civil engineering design - the Gardiner Expressway. Proceedings of the Canadian Engineering

Bunce, S., \& Desfor, G. (2007). Introduction to "Political ecologies of urban waterfront transformations". Cities, 24(4), 251-258.

Busquets, J. (2005a). Barcelona (Vol. 2). Actar D.

Busquets, J. (2005b). Barcelona revisited: Transforming the city within the city. City Edge: Case Studies in Contemporary Urbanism, 34-49.

Busquets, J. (2006). Cities, X Lines: A New Lens for the Urbanistic Project. Harvard University, Graduate School of Design.

City of Toronto Archives (n.d.a). Parkdale. Accessed on April 13, 2015 from: https://gencat4.eloquentsystems.com/webcat/request/Action?ClientSession=41bb6713:14ca6da5b7a:-

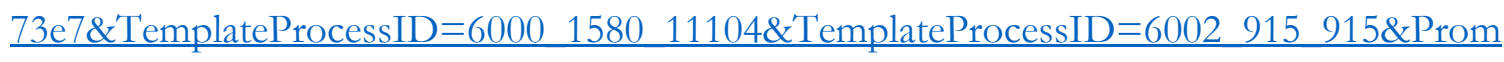
ptID $=\&$ ParamID $=\& C M D \quad \% 28$ DetailRequest $\% 29[0]=\&$ Process $I D=6002 \quad 1023 \% 280 \% 29$ $\underline{\text { \&KeyValues }=\text { KEY } 19123}$

City of Toronto Archives (n.d.b) Grand Trunk Railway Company of Canada. Accessed on April 13, 2015 from: https://gencat4.eloquent- 
systems.com/webcat/request/Action?ClientSession=41bb6713:14ca6da5b7a:-

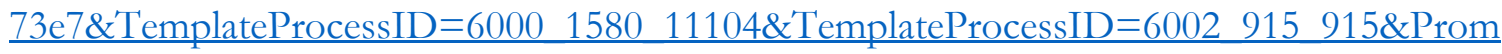

ptID=\&ParamID $=\& C M D \quad \% 28$ DetailRequest $\% 29[0]=\&$ ProcessID $=6002 \quad 1023 \% 280 \% 29$

$\underline{\& K e y V a l u e s=K E Y ~} 37725$

City of Toronto Archives (n.d.c). Sunnyside Park. Accessed on March 5, 2015 from:

https://gencat4.eloquent-

systems.com/webcat/request/Action?ClientSession=41bb6713:14ca6da5b7a:-

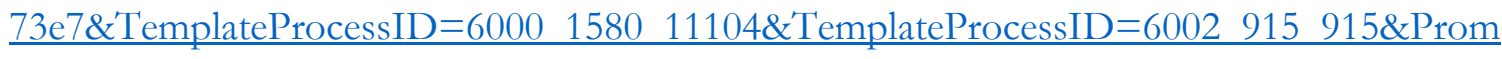

ptID $=\&$ ParamID $=\& C M D \quad \% 28$ DetailRequest $\% 29[0]=\&$ ProcessID $=6002 \quad 1023 \% 280 \% 29$

$\underline{\& \text { KeyValues }=\text { KEY } 29923}$

City of Toronto Archives (n.d.d). Lake Shore Boulevard. Accessed on March 5, 2015:

https://gencat4.eloquent-

systems.com/webcat/request/Action?ClientSession $=41 \mathrm{bb} 6713: 14 \mathrm{ca} 6 \mathrm{da} 5 \mathrm{~b} 7 \mathrm{a}:-$

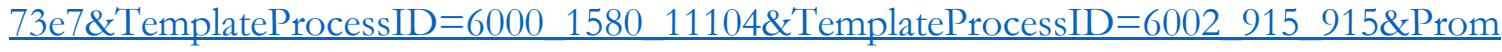

ptID $=\&$ ParamID $=\& C M D \quad \% 28$ DetailRequest $\% 29[0]=\&$ ProcessID $=6002 \quad 1023 \% 280 \% 29$

$\underline{\text { \&KeyValues=KEY } 1209}$

City of Toronto (n.d.a). Neighbourhood Profiles. Accessed on March 5, 2015 from:

http://www1.toronto.ca/wps/portal/contentonly?vgnextoid=ae17962c8c3f0410VgnVCM1 0000071d60f89RCRD\&vgnextchannel=1e68f40f9aae0410VgnVCM10000071d60f89RCRD

City of Toronto (n.d.b) Toronto Strong Neighbourhoods Strategy 2020. Accessed on March 5, 2015 : http:/ $/$ www1.toronto.ca/wps/portal/contentonly?vgnextoid=42653745ba9a9410VgnVCM1 $\underline{0000071 d 60 f 89 R C R D}$

City of Toronto (2007). Central Waterfront Secondary Plan. 
City of Toronto (2009). Western Toronto Waterfront Master Plan. Accessed on January 5, 2015 from: http://www1.toronto.ca/city of toronto/waterfront secretariat/files/pdf/wwmpfinal-report-21aug09.pdf

City of Toronto (2010). Avenues \& Mid-Rise Building Study. Accessed on March 29 from: http://www1.toronto.ca/City $\% 200 f \% 20$ Toronto/City $\% 20 \mathrm{Planning} / \mathrm{Urban} \% 20 \mathrm{Design} / \mathrm{Mi}$ d-rise/midrise-FinalReport.pdf

City of Toronto (2011). South Parkdale: Neighbourhood Census / NHS Profile. Accessed on March 10, 2015 from: http://www1.toronto.ca/City $\% 200 f \% 20$ Toronto/Social $\% 20$ Development, $\% 20$ Finance $\% 2$ 0\&\%20Administration/Neighbourhood $\% 20$ Profiles/pdf/2011/pdf4/cpa85.pdf

City of Toronto (2013a). Parks Plan 2013-2017.

City of Toronto (2013b). West Queen West Study: Background File. Accessed on March 2, 2015 from: http://www.toronto.ca/legdocs/mmis/2013/te/bgrd/backgroundfile-62569.pdf

City of Toronto. (2013c). City of Toronto Property Data Map 2013. Toronto, ON. Retrieved from: Ryerson University Geospatial Map and Data Centre.

City of Toronto (2014a). Toronto Strong Neighbourhoods Strategy 2020 Retrieved on March 2, 2015 from: http://www.toronto.ca/legdocs/mmis/2014/cd/bgrd/backgroundfile67382.pdf

City of Toronto. (2014b). Toronto.ca/open Data Catalogue [Toronto Parks shapefile]. Toronto, ON: Geospatial Competency Centre.

Corner, J. (2006). Terra Fluxus. In Waldheim, C. (Ed.), The landscape urbanism reader. (pp. 21-33). Princeton Architectural Press.

Deitz, P. (2005). Landform Future-Architects and landscape architects are engaging topography. Architectural Record, 193(10), 94-101. 
Desfor, G. (1993). Restructuring the Toronto Harbour Commission: land politics on the Toronto waterfront. Journal of Transport Geography, 1(3), 167-181.

Desfor, G., Goldrick, M., \& Merrens, R. (1989). A political economy of the waterfrontier: Planning and development in Toronto. Geoforum, 20(4), 487-501

Ellin, N. (1999). Postmodern urbanism. Princeton Architectural Press.

Fein, M. R. (2011). Tunnel Vision: “Invisible” Highways and Boston’s “Big Dig” in the Age of Privatization. Journal of Planning History, 1538513211425209.

Girot, C. (2006). Vision in motion: representing landscape in time. In Waldheim, C. (Ed.), The landscape urbanism reader. (pp. 87-103). Princeton Architectural Press.

Gissen D. (2011). The Architectural Reconstruction of Nature. In Allen, S., \& McQuade, M. (Eds.), Landform building: architecture's new terrain. (pp. 456-463). Lars Müller Publishers.

Gordon, D. L. (1996). Planning, design and managing change in urban waterfront redevelopment. Town Planning Review, 67(3), 261.

Gordon, D. L. (1997). Managing the changing political environment in urban waterfront redevelopment. Urban Studies, 34(1), 61-83.

Gospodini, A. (2002). European cities in competition and the new 'uses' of urban design. Journal of Urban Design, 7(1), 59-73.

Lehrer, U., \& Laidley, J. (2008). Old mega-projects newly packaged? Waterfront redevelopment in Toronto. International Journal of Urban and Regional Research, 32(4), 786-803.

Manza, C. (2013). How Much Are Homes in Toronto? Accessed from The Globe and Mail: http://www.theglobeandmail.com/life/home-and-garden/real-estate/exclusive-how-muchare-homes-in-your-toronto-neighbourhood/article4520994/

Mass Dot (n.d.). Project Background. Accessed on April 4, 2015, from: https://www.massdot.state.ma.us/highway/TheBigDig/ProjectBackground.aspx 
Metro Archives (1992). Timeline Gardiner and DVP. City of Toronto Archives.

Mossop, E. (2006). Landscapes of infrastructure. In Waldheim, C. (Ed.), The landscape urbanism reader. (pp. 163-177). Princeton Architectural Press.

Ottawa Neighbourhood Study. (n.d.). Definitions. Accessed on April 3, 2015, from http://neighbourhoodstudy.ca/variablesdefinitions/

Pearson, C. A. (2007). Olympic Sculpture Park, Washington (Weiss/Manfredi Architecture). Architectural Record, 195(7), 110-117.

Pollak, L. (2006). Constructed ground: Questions of Scale. In Waldheim, C. (Ed.), The landscape urbanism reader. (pp. 125-139). Princeton Architectural Press.

Proposed lakeshore expressway for Municipality of Metropolitan Toronto : comparison of alternatives, Humber River to Spadina Avenue : functional report (1954). Municipality Metropolitan Toronto. City of Toronto Archives Fonds 220, Series 10, Item 45

Reeves, W. (1993). Visions for the Metropolitan Toronto Waterfront: I. Toward comprehensive planning, $1852-$ 1935. Centre for Urban \& Community Studies, University of Toronto.

Steiner, F. (2011). Landscape ecological urbanism: Origins and trajectories. Landscape and urban planning, 100(4), 333-337.

Tajima, K. (2003). New estimates of the demand for urban green space: implications for valuing the environmental benefits of Boston's big dig project. Journal of Urban Affairs, 25(5), 641-655.

Tatom, J. (2006). Urban highways and the reluctant public realm. In Waldheim, C. (Ed.), The landscape urbanism reader. (pp. 179-195). Princeton Architectural Press.

The Associated Press (2012). New estimate puts rising big dig costs at 24.3 billion. Accessed on March 31, 2015 from: http://boston.cbslocal.com/2012/07/10/new-estimate-puts-rising$\underline{\text { big-dig-costs-at-24-3-million/ }}$ 
Toronto waterfront development : 1912-1920. (1913). The Toronto Harbour Commissioners, Fonds 89, File 5. City of Toronto Archives.

The Trust for Public Land (2012). City Park Facts Report. Retrieved on February 18, 2015 from: https://www.tpl.org/2012-city-park-facts-report-0

Waldheim, C. (2006). Landscape as urbanism. In Waldheim, C. (Ed.), The landscape urbanism reader. (pp. 35-53). Princeton Architectural Press.

Wall, A. (1999). Programming the urban surface. Recovering Landscape, 234.

Waterfront Toronto (n.d.). About Us. Retrieved February 9, 2015, from http://www.waterfrontoronto.ca/about us

Waterfront Toronto (2009). Fact Sheet: Gardiner Expressway. Accessed on February 18, 2015 from: http://www1.toronto.ca/wps/portal/contentonly?vgnextoid=eebc186e20ee0410VgnVCM1 $\underline{\text { 0000071d60f89RCRD }}$

Weiss /Manfredi (2015). Olympic Sculpture Park. Accessed on March 29, 2015 from: http://www.seattleartmuseum.org/visit/olympic-sculpture-park

Weller, R. (2006). An art of instrumentality: thinking through landscape urbanism. In Waldheim, C. (Ed.), The landscape urbanism reader. (pp. 69-85). Princeton Architectural Press.

Whitzman, C. (2010). Suburb, Slum, Urban Village: Transformations in Toronto's Parkdale Neighbourbood, 1875-2002. UBC Press.

Whitzman, C. (2003). The dreams attached to places: From suburb, to slum, to urban village in a toronto neighbourhood, 1875-2002 (Order No. NQ86567). Available from ProQuest Dissertations \& Theses A\&I; ProQuest Dissertations \& Theses Full Text. (305312605). Retrieved from http://ezproxy.lib.ryerson.ca/login?url=http://search.proquest.com/docview/305312605?a ccountid $=13631$ 
Image References

Aerial views of Gardiner Expressway (1958). Municipality of Metropolitan Toronto. Fonds 220, Series 65, File 47. City of Toronto Archives.

Goad, Charles E (1884). Insurance Plan of Toronto, Ontario, Canada. Toronto: C.E. Goad.

Goad, Charles E (1890). Insurance Plan of Toronto, Ontario, Canada. Toronto: C.E. Goad.

Goad, Charles E (1913). Insurance Plan of Toronto, Ontario, Canada. Toronto: C.E. Goad.

Goad, Charles E (1924). Insurance Plan of Toronto, Ontario, Canada. Toronto: C.E. Goad.

Seattle Olympic Sculpture Park -DETAILED DRAWINGS [Map]. (2008). By Jasmine Maggs.

Retrieved on April 10, 2015 from: http://www.coroflot.com/jazzymaggs/seattle-olympicsculpture-park-detailed-drawings

South Parkdale Map [Map] (n.d.). City of Toronto. Retrieved on April 1, 2015 from:

http://www1.toronto.ca/wps/portal/contentonly?vgnextoid=2aa2ed1 ea61e1410VgnVCM1 0000071d60f89RCRD\&vgnextchannel=1e68f40f9aae0410VgnVCM10000071d60f89RCRD

Sunnyside bathing station [Photograph]. (1924). William James family, Fonds 1244, Item 219A. City of Toronto Archives.

Sunnyside, looking n.w., showing St. Joseph's Hospital (formerly Sacred Heart Orphanage), The Queensway, in right background (1934). Toronto Public Library. Retrieved March 29, 2015 from: http://www.torontopubliclibrary.ca/detail.jsp?Entt=RDMDC-PICTURES-R$\underline{598 \& R=D C-P I C T U R E S-R-598}$

Temporary wooden bridge used during grade separation activities, Jameson Avenue [Photograph] (1911). City of Toronto. Fonds 1568, Item 505. City of Toronto Archives

Track, looking west from east of Jameson Avenue crossing (near station 200+00) [Photograph] (1910). City of Toronto. Fonds 200, Series 372, Subseries 51, Item 56. City of Toronto Archives 
[Untitled Map of Parkdale] (1851). Personal Communication.

[Untitled Map of Parkdale] (1860). Personal Communication.

[Untitled Map of Toronto] (1913). Toronto Historic Maps. Retrieved March 29, 2015 from: http://peoplemaps.esri.com/toronto/

[Untitled Map of Toronto] (1924). Toronto Historic Maps. Retrieved March 29, 2015 from: http://peoplemaps.esri.com/toronto/

[Untitled Photograph of Barcelona’s Ronda Litoral] (n.d.). Personal Communication

[Untitled Photograph of Boston’s Big Dig] (n.d.). Retrieved April 8, 2015 from:

http://introufba2012.blogspot.ca/

[Untitled Photograph of Demolished South Parkdale] (1957). Retrieved March 25, 2015 from: http://www.torontosun.com/2014/04/25/gardiner-expwy-repairs-comes-60-years-after$\underline{\text { constructions-began }}$

[Untitled Photograph of Parkdale] (n.d.) City of Toronto. Series 1465, File 771. City of Toronto Archives.

[Untitled Photograph of Olympic Sculpture Park] (n.d.). Weiss/Mandredi. Retrieved March 3, 2015 from: http:/ /www.weissmanfredi.com/

[Untitled Photograph of Olympic Sculpture Park Sketch] (n.d.). Weiss/Mandredi. Retrieved March 3, 2015 from: http://www.weissmanfredi.com/

[Untitled Photograph of Sunnyside] (1949). BlogTo. Retrieved March 29, 2015 from: http://www.blogto.com/city/2013/10/what lake shore boulevard used to look like in $\underline{\text { toronto }}$

[Untitled Photograph of Sunnyside] (1969). BlogTo. Retrieved March 29, 2015 from: http://www.blogto.com/city/2013/10/what lake shore boulevard used to look like in $\underline{\text { toronto }}$ 
Wadsworth \& Unwin's map of the village of Parkdale compiled and drawn from plans filed in the registry office and the most recent surveys [Map]. (1879). Retrieved March 23, 2015, from: http://static.torontopubliclibrary.ca/da/images/LC/maps-r-31.jpg 